\begin{abstract}
UNIVERSIDADE DE SÃO PAULO
ESCOLA DE COMUNICAÇÕES E ARTES

DEPARTAMENTO DE ARTES CÊNICAS
\end{abstract}

PAULA CHAGAS AUTRAN RIBEIRO

\title{
Teoria e prática do
}

\section{Seminário de Dramaturgia do}

\section{Teatro de Arena}

São Paulo

2012 


\section{Teoria e prática do Seminário de Dramaturgia do}

\section{Teatro de Arena}

Dissertação apresentada ao Programa de Pós-

Graduação em Artes, Área de Concentração Artes

Cênicas, Linha de Pesquisa Teoria e Prática do

Teatro, da Escola de Comunicações e Artes da

Universidade de São Paulo, como exigência parcial

para a obtenção do Título de Mestre em Artes, sob

a orientação do Prof. Dr. Sérgio de Carvalho.

São Paulo

2012 
Autorizo a reprodução e divulgação total ou parcial deste trabalho, por qualquer meio convencional ou eletrônico, para fins de estudo e pesquisa desde que citada a fonte.

\section{Catalogação na publicação \\ Serviço de Biblioteca e Documentação \\ Escola de Comunicações e Artes da Universidade de São Paulo}

\section{Ribeiro, Paula Chagas Autran}

Teoria e prática do seminário de dramaturgia do Teatro de Arena / Paula Chagas Autran Ribeiro - São Paulo : P. C. A. Ribeiro, 2012.

$164 \mathrm{p}$.

Dissertação (Mestrado) - Escola de Comunicações e Artes / Universidade de São Paulo.

Orientador: Sérgio Ricardo de Carvalho Santos

1. Dramaturgia 2. Dialética 3. Palco de arena 4. Teatro de Arena I. Título II. Santos, Sérgio Ricardo de Carvalho

CDD 21.ed. -792 
Paula Chagas Autran Ribeiro

Teoria e Prática do Seminário de Dramaturgia do Teatro de Arena

Dissertação apresentada ao
Programa de Pós-Graduação em Artes,
Área de Concentração Artes Cênicas, da
Escola de Comunicações e Artes da
Universidade de São Paulo, para a
obtenção do Título de Mestre em artes

Aprovado em:

Banca Examinadora:

Prof. Dr. Instituição

Julgamento Assinatura

Prof. Dr. Instituição

Julgamento Assinatura

Prof. Dr. Instituição

Julgamento Assinatura 
A Arthur, meu filho. 


\section{AGRADECIMENTOS}

A Sérgio de Carvalho, pela orientação e pela serenidade ao ver sua orientanda tão segura de si transformar-se - no meio deste trabalho - em uma mãe de primeira viagem, com todas as loucuras e inseguranças que essa condição acarreta.

A meus pais, Suely e Pedro, por terem incutido em mim os valores do trabalho e da liberdade, bens inalienáveis, além do amor. $E$ por terem sempre segurado as minhas ondas sem julgamento nenhum. Obrigada!

A minhas avós Lourdes e Deda; e aos sempre na memória Pedro, Eny e Evaristo, por me mostrarem com suas vidas no circo e no teatro, a força da arte popular e brasileira, feita em família, na raça e no amor de gerações que se perpetuam.

A Vicente Scopacasa, por estar sempre disponível com seu computador e seu humor inteligente. Além das conversas tranquilizadoras em meio ao meu caos cotidiano.

A minhas irmãs Gabriela e Carolina e meu compadre Silvestre, pela luz, colo e paciência de toda vida, mas principalmente nesses três últimos anos, nos quais o furacão se instalou em minha vida e em nossas casas. Sem vocês, nada seria possível!

A Arthur, Cecília, Théo e Eduardo, que me mostraram que se a vida não tem sentido, pode ter muita graça. Amo vocês!

A Mauro Marabesi, por ter atravessado a rua naquele fevereiro, sentado à minha mesa naquele café e ter soltado a minha mão apenas quando o Arthur fez três meses. E por, 23 anos depois, ter tentado novamente o impossível...

À família Marabesi: Regina, Adalberto, Aline e Marquinhos. Por terem segurado toda a onda e remado conosco com tanta alegria!

Carlinhos, por ter sido mais do que um parente! Por todo o cardápio do Roma, pelas conversas e pela reincidente frase quando tudo parecia tão escuro: você não está sozinha! Nunca estive, obrigada!

Minhas queridas amigas da vida toda, Cris, Letícia, Joana e Rhena. Mesmo sem poder vê-las muito, saber que estão aí faz minha vida mais feliz! 
Patrícia Gomes e Luzia Neves, parceiras de jornada. Sem o afeto cristalino que dedicam ao Arthur eu não teria paz alguma para escrever.

Minha extensa família: Mônica Xavier, Tia Claudia, Bá, Tia Nem, Tio Rafael, Bebê, Marcello, Lucca, Tia Lucita, Patrícia, Marcelo, Mariana, Tio Marcos, Tio Paulo, Tia Vera. Por terem me dado colo nesses anos tumultuados e estendido esse amor ao Arthur. Obrigada!

Aos amigos que pensam e fazem teatro comigo: Drika, Dênio, Dilson, Luis Eduardo, Luis Indriunas e Thereza, que em cada linha caminharam e pensaram comigo! Obrigada pelo companheirismo, pelo ombro e pelo afeto.

A José Cetra, pelos livros e programas emprestados que me pouparam muito tempo de pesquisa e por seu amor incondicional ao teatro!

À Sandra Ungaretti, pelo profissionalismo e generosidade em me auxiliar a organizar meu caos mental!

A Nelson Xavier, Chico de Assis e Lauro César Muniz, pelos depoimentos esclarecedores e emocionados. Obrigada!

Às professoras Maria Silvia Betti e Beth Azevedo, pela dedicação na minha qualificação, indicando caminhos e apontando questões imprescindíveis na continuidade do trabalho.

À Andréia, funcionária da ECA, pelo profissionalismo e dedicação.

À FAPESP pela bolsa que me deu um pouco de tranqüilidade para realizar esse trabalho.

$\mathrm{E}$, finalmente, ao pioneirismo, garra e loucura dos integrantes do Arena, que mudaram a face da arte em nosso país e mostraram que ao artista brasileiro só resta uma opção: realizar seus sonhos... 


\section{RESUMO}

Este estudo pesquisa o Seminário de dramaturgia do Teatro de Arena, que ocorreu entre os anos de 1958 e 1961, na cidade de São Paulo. A partir da recuperação crítica da história do Seminário serão analisados os procedimentos de pesquisa formal ali empreendidos, que resultaram na produção de sete peças levadas à cena no período. O Seminário de Dramaturgia do Teatro de Arena forma uma geração de artistas que consolida a modernização do teatro brasileiro também no campo da dramaturgia. Sua importância histórica e cultural se dá não só no âmbito da história do teatro, mas no da cultura brasileira como um todo. Sua influência decorre não apenas dos trabalhos dos melhores autores ali surgidos, como Vianinha e

Guarnieri, e suas criações estéticas, mas também de um arsenal crítico que contribuiu para a criação de ações culturais politizadas como as do CPC (Centro Popular de Cultura) e forneceu modelos para a crescente produção cinematográfica e televisiva. Assim, o estudo dos debates, do contexto e das peças do Seminário se faz essencial para a melhor compreensão da história recente da cultura brasileira no que se refere ao desenvolvimento dos seus padrões de representação dramatúrgica. 


\section{ABSTRACT}

This study investigates the Seminary of Dramaturgy of the Arena Theater (Teatro de Arena) during the years between 1958 and 1961 in the city of São Paulo. The procedures of a formal research there outlined from a critical recovery of the history of the Seminary which resulted in the production and staging of 7 plays at that time will beanalyzed. The Seminary of Dramaturgy of the Arena Theater draws up a generation of artists that also consolidates the modernization of the brazilian theater in the dramaturgy field. Its historical and cultural importance occurs in the history of theater as well as in the brazilian culture. Its influence not only derives from some of the pieces written by the best artists from there emerged such as Vianinha and Guarnieri , from their esthetic creations but also from a critical arsenal that contributed for the creation of cultural politicized actions such as CPC (Popular Culture Center) and supplied models for the increasing production of cinema and television. Therefore the study of the debates, contexts and plays of the Seminary is essential for a better comprehension of the recent history of brazilian culture regarding the development of dramaturgic representation standards. 


\section{SUMÁRIO}

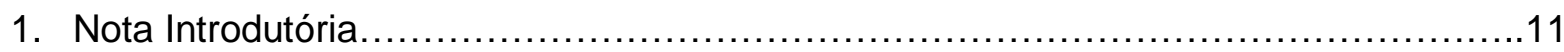

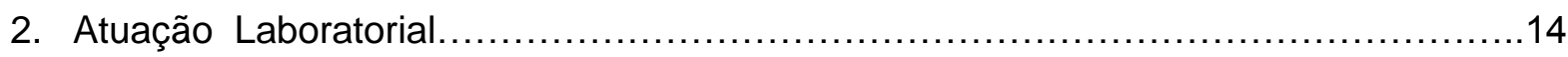

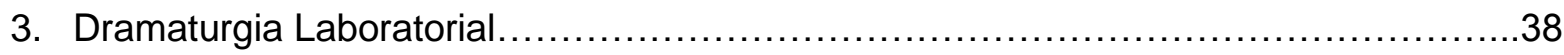

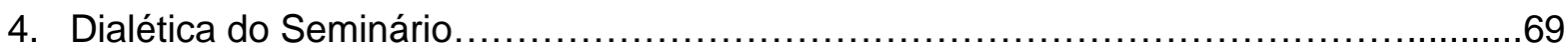

5. Apontamentos para uma nova dramaturgia.....................................................101

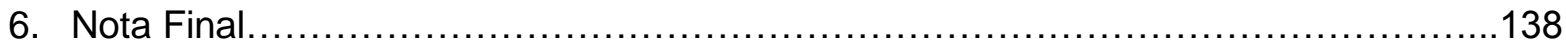

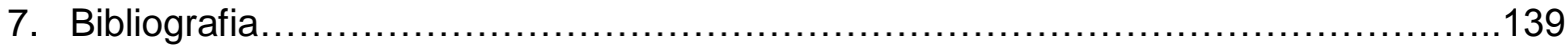

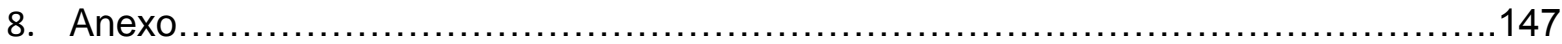




\section{Nota Introdutória}

O Seminário de Dramaturgia do Teatro de Arena, ocorrido entre os anos de 1958 e 1961, forma uma geração de artistas que consolida a modernização do teatro brasileiro no campo da dramaturgia e lhe imprime um rumo politizado.

Apesar de bem discutida em diversos estudos publicados, a história do Teatro de Arena de São Paulo, costuma ser nebulosa quando se trata do trabalho realizado no Seminário de Dramaturgia. Os poucos documentos existentes, sendo a maioria baseados em memória oral, costumam ser lacônicos sobre os reais aspectos técnicos e estéticos que pautavam os debates formativos do Seminário.

Além disso, são poucos os estudos que enfrentaram a difícil questão do entrecruzamento das intenções dramatúrgicas e ideológicas e a prática cênica. Com o intuito de contribuir para o debate, este trabalho se propõe a investigar de que maneira o Teatro de Arena, com seu Seminário de Dramaturgia, procurou refletir sobre uma pedagogia da dramaturgia capaz de enfrentar a questão de uma representação nacional e popular.

É, portanto, deste ângulo que o estudo se coloca: o Seminário de Dramaturgia do Teatro de Arena cumpriu um papel inovador como meio de modificação do ofício do dramaturgo, coletivizando as práticas no mesmo movimento em que une de maneira radical a teoria e a prática. É isso o que lhes permiteu levar a cabo um projeto de reflexão sobre teatro brasileiro que exigiu tomada de partido em relação não só aos 
conteúdos políticos, mas também à forma como esses conteúdos seriam trabalhados no palco.

Esse processo retira, a nosso ver, a idéia de que o autor seja uma espécie de criador solitário. Da mesma maneira que um ator e um diretor, o dramaturgo precisa de formação, tempo de experimentação de sua obra e um constante exercício de prática teatral, que só se efetiva no palco.

O objetivo central da pesquisa foi investigar de que forma os procedimentos teóricos e práticos do Seminário de Dramaturgia do Teatro de Arena contribuíram para a consolidação de uma visão de dramaturgia interessada em compreender sua função diante de um processo histórico.

O projeto pedagógico do Seminário corresponde a uma necessidade de formação contínua em que o debate sobre a dramaturgia brasileira passou a depender de uma atitude de pesquisa laboratorial que não estava dada, precisava ser construída através de debates não só técnicos, mas também políticos, sociais e estéticos.

A idéia de que havia ali um sectarismo exagerado, que ofusca qualquer outra qualidade, não corresponde à verdade, ainda que muitas declarações de seus integrantes reafirmem essa idéia.

O que estava em jogo, com toda força, era justamente uma prática do debate em bases dialéticas. O pensamento dialético passou a ser uma das principais ferramentas de trabalho do grupo e é no Seminário que ele mostra sua capacidade mobilizadora. Na medida em que o conteúdo engendra a sua forma e é determinado, portanto, por 
ela, dialeticamente ${ }^{1}$, a história do Seminário é também uma história de aprendizado experimental da dialética.

Mais do que um conjunto de textos acabados para o palco, criou-se ali a idéia e a prática de uma formação em que o assunto e a orientação crítica engendram sua forma. O Seminário inaugura uma concepção de trabalho artístico que segue como um modelo de um teatro por realizar.

\footnotetext{
${ }^{1}$ Conforme idéia de Peter Szondi em Teoria do Drama Moderno (1880-1950). São Paulo: Cosac \& Naify, 2003.
} 


\section{Capítulo 1}

\section{Atuação Laboratorial}

O Seminário de Dramaturgia do Teatro de Arena é talvez o primeiro projeto de estudo e produção sistemática de uma dramaturgia nacional moderna. Fundado em 1958, "funcionou com regularidade semanal por aproximadamente dois anos, com interrupções"2. Sua contribuição para uma mudança nos caminhos da modernização do teatro brasileiro é inestimável. Uma geração de dramaturgos com atuação no teatro, no cinema e na televisão foi influenciada pelos debates do Seminário de Dramaturgia do Teatro de Arena. Na forma de um encontro semanal de leitura e debate sobre textos dos jovens autores, o Seminário nasceu de uma evolução do curso de dramaturgia ministrado nos anos anteriores por Augusto Boal e mantém vínculos profundos com a prática artística, política e pedagógica das encenações produzidas no Teatro de Arena.

O Seminário não era restrito aos integrantes da companhia. Estudiosos convidados ampliavam os temas discutidos pelos dramaturgos. Do Seminário saíram sete textos de autores nacionais - entre eles Chapetuba Futebol Clube, de Oduvaldo Vianna Filho, o Vianinha, e Revolução na América do Sul, de Boal ${ }^{3}$ - e também uma nova maneira de produção da escrita dramática e de espetáculos teatrais. A grande novidade estava na forma compartilhada com que o dramaturgo concebia seu texto, em

\footnotetext{
${ }^{2}$ Guimarães, Carmelinda Seminário de Dramaturgia: Uma Avaliação 17 anos Depois. In Revista Dionysos, número 24. Rio de Janeiro: Ministério da Educação e Cultura- Funarte, 1978, p.67. No presente trabalho usaremos a data final do Seminário como sendo 1961, quando foi apresentada Testamento do Cangaceiro, de Chico de Assis, última peça encenada a partir das discussões ali empreendidas.

${ }^{3}$ As demais peças encenadas a partir do Seminário foram: Gente como a Gente, de Roberto Freire, A Farsa da Esposa Perfeita, de Edy Lima Fogo Frio, de Benedito Ruy Barbosa, Pintado de Alegre, de Flávio Migliaccio e $O$ Testamento do Cangaceiro, de Chico de Assis.
} 
meio a debates políticos, estéticos e artísticos. Construía-se ali uma pedagogia dramatúrgica sem precedentes no teatro do país.

O sentido geral da novidade histórica do Seminário de Dramaturgia se liga, assim, a um deslocamento da função e do trabalho da dramaturgia (a partir de sua conexão radical com a prática) e de uma inédita coletivização da escrita, experiência até então impensável na linha de modernização do teatro brasileiro, que se tornava hegemônica a partir do modelo de maior desenvolvimento empresarial do Teatro Brasileiro de Comédia (TBC). O texto e a cena nasciam interligados, sendo seu tema e sua forma de representação - problematizados a um só tempo.

Além disso, o trabalho do dramaturgo se confundia com outras operações do teatro, podendo ser ele também ator, diretor e técnico de seus espetáculos e dos espetáculos dos outros integrantes do Seminário. Estava em jogo, portanto, uma reelaboração da função do dramaturgo, que pensava, ao mesmo tempo, a necessidade de uma consciência formativa e metodológica.

Em meio às discussões das peças e de suas montagens, foi empreendido no Seminário um amplo esforço de reflexão metodológica sobre uma dramaturgia brasileira de orientação nacional e popular.

\section{Uma prática de estúdio teatral}


Para que se compreenda as razões dessa interação de campos que se materializa no Seminário - teoria e prática, produção e formação, crítica de ordem estética e política - é preciso descrever as feições particulares do trabalho teatral do Teatro de Arena em sua história anterior. Mais do que uma jovem companhia de artistas profissionais, o Arena se tornou um lugar de reflexão e experimentação teatral porque soube - em grande parte de sua existência - conjugar de modo produtivo as diferentes perspectivas de seus integrantes, oriundos de formações teatrais muito distintas.

E talvez o critério fundamental dessa interação tenha sido a vontade de criar peças que refletissem o momento histórico no qual estavam inseridos. A teorização sobre a relação entre dramaturgia e a história atual tornava-se uma necessidade surgida no entrecruzamento da escrita da peça e sua efetivação no palco. Para alcançar essa interação, que só pode se dar no campo de uma crítica da teatralidade ${ }^{4}$, tornou-se crucial o estudo detalhado de cada um de seus aspectos produtivos (o trabalho do ator, a cenografia, a escrita etc.) de modo que a perspectiva do processo de aprendizado passasse a orientar o grupo em suas realizações culturais.

É importante ressaltar que o Teatro de Arena não surgiu a partir de um plano estético organizado, mas antes como uma opção teatral definida por um certo formato

\footnotetext{
${ }^{4} \mathrm{O}$ termo teatralidade é aqui entendido como a qualidade específica da encenação teatral, como explica Patrice Pavis: "A teatralidade seria aquilo que, na representação ou no texto dramático, é especificamente teatral (ou cênico)... A teatralidade não surge mais como uma qualidade ou uma essência inerente a um texto ou a uma situação, mas como um uso pragmático da ferramenta cênica, de maneira a que os componentes da representação se valorizem reciprocamente". Dicionário de Teatro. São Paulo: Editora Perspectiva, 2001, pp. 372, 373, 374.
} 
de palco que se disseminava no pós-guerra. O Arena, fundado em $1953^{5}$, foi o primeiro teatro desse tipo na América Latina, e modificou profundamente as relações entre palco e platéia, ainda que em um primeiro momento essa relação não fosse percebida em toda a sua dimensão, como reflete a pesquisadora Mariângela Alves de Lima:

"Não se pode dizer também que a proposta original do Arena fosse muito inovadora. Mas havia a ideia do teatro de arena. Na linguagem teatral as alterações de espaço provocam profundas alterações de significado... Entretanto a idéia da função social do teatro... só foi claramente definida pelo grupo a partir de 1958..."

As primeiras peças ali apresentadas sucediam-se sem maior planejamento estético (ou ético-político), sendo a definição dos espetáculos guiada por uma escolha de um repertório de "teatro moderno", com tendência a uma dramaturgia realista que facilitasse o diálogo com uma cena íntima do ponto de vista espacial.

Por outro lado, na medida em que as "alterações de espaço provocam profundas alterações de significado", é importante assinalar que o espaço do Arena - pequeno e

\footnotetext{
5 “Em 1953, saindo da EAD, José Renato se propõe a organizar uma companhia permanente de teatro de arena. Reunindo um grupo de jovens atores ainda desligados do novo mercado de trabalho, José Renato começou a discussão para formar as bases de uma nova companhia... A estréia da "Companhia Teatro de Arena" acontece no dia 11 de abril de 1953, com a peça Esta Noite é Nossa." Lima, Mariângela Alves de. História das Idéias. In Dionysos, número 24. Rio de Janeiro: Ministério da Educação e Cultura- DAC. Funarte, 1978, pp. 31, 32 e 33.

${ }^{6}$ Alves de Lima, Mariângela. Teatro Brasileiro- Uma reflexão In Dionysos. Especial TBC, Rio de Janeiro: Ministério da Educação e Cultura- Funarte, 1980, p. 26.

${ }^{7}$ Aqui, teatro moderno é entendido como proposto por Iná Camargo Costa: "Antes de mais nada, pode ser útil dar alguns dos motivos que justificam a escolha da incômoda expressão "teatro moderno". Em primeiro lugar, ela é a mais frequentemente usada, não só por estabelecer uma oposição ao "velho" teatro profissional das companhias de atores como Procópio Ferreira e Jayme Costa, como também, por identificar uma postura em relação ao teatro bastante afinada com o período ("de modernização") que se abre no Brasil com o pós-guerra e a queda da ditadura de Vargas". Costa, Iná Camargo. A Produção Tardia do Teatro Moderno no Brasil. In Sinta o Drama, Rio de Janeiro: Editora Vozes, 1998, pp.12,13.
} 
refratário às grandes cenografias - como que impunha um padrão anti-ilusionista da encenação (e nesse sentido épico), pela intimidade da relação entre palco e platéia e pela ausência de cenários figurativos.

Desse modo, a tendência à linguagem realista dada pela escolha do repertório era como que contrabalançada pelas supressões épicas de encenação em formato de arena $^{8}$, numa espécie de distanciamento constitutivo que necessariamente exigia do ator uma nova postura em cena ${ }^{9}$. Muito da diferente concepção de teatralidade do Arena, em relação ao TBC, deve ser discutida à luz dessa disposição cênica particular.

Mesmo com essas contradições formais já anunciadas, a mudança de paradigma maior no projeto do Teatro de Arena se efetivou quando, em 1955, ocorreu a fusão com o Teatro Paulista do Estudante (TPE), com a entrada de seus jovens integrantes, entre eles Gianfrancesco Guarnieri e Vianinha, influenciados pelo diretor e crítico Ruggero Jacobbi. No ano seguinte, 1956, se junta ao grupo Augusto Boal e aprofunda as mudanças em curso. Sua entrada, algo casual, veio de uma sugestão de Sábato Magaldi a José Renato, até então único diretor do Arena ${ }^{10}$. Os primeiros trabalhos de Boal dentro do Arena seguiam a mesma lógica anterior, trazendo para o

\footnotetext{
8 "Qualquer estilo que possa ser ensaiado fora do proscênio do palco pode ser usado no teatro de arena. A peça pode ser feita em um estilo completamente naturalista, ou completamente estilizada. Não há restrição quanto ao estilo, podemos criar um realismo tanto quanto um simbolismo, expressionismo ou surrealismo, dependendo dos requisitos da peça". Jones, Margo. Theatre In The Round. New York: McGraw-Hill Book Company, 1965, p. 109

9 "Por mais que haja comunicação, a arena, por sua disposição formal, em que torna os personagens mais vulneráveis pela presença próxima do ator, mantém uma tensão extremamente rica para o teatro: a aproximação e o distanciamento. Assim, ela pode configurar a forma ideal para um teatro que se deseje transformador da realidade". Soares, Lúcia Maria Mac Dowell. O Teatro Político do Arena e de Guarnieri. In Monografias, Rio de Janeiro: INACEN, 1980, p. 19

10 "Foi então que senti a necessidade de dividir a direção com outra pessoa. Sábato Magaldi me sugeriu o nome de um rapaz recém chegado dos Estados Unidos, onde fora fazer um curso de química, mas que até já tinha escrito teatro. Era o Augusto Boal. Contratamo-lo para trabalhar conosco." Pécora, José Renato. In Ciclo de Palestras Sobre o Teatro Brasileiro. Rio de Janeiro: MINC-INACEN, 1984, p. 13
} 
palco peças do moderno teatro estrangeiro, escolhidas segundo critérios de sua suposta boa qualidade literária no padrão do drama moderno. Apesar de não ter entrado no Arena já com um projeto estabelecido, Boal trazia a experiência das aulas que havia tido nos EUA, que incluíam um curso de dramaturgia com John Gassner e a observação do trabalho dos atores no Actor's Studio.

Boal tem clareza sobre o sentido de suas escolhas iniciais quando faz a autocrítica de seu trabalho em peças como A Mulher do Outro, de Sidney Howard encenada em 1958:

"Nem sequer para mim escolhia: eu era um Columbia Man e essa formação universitária me fazia pensar em textos literários, obras-primas de compêndios, sem levar em conta realidades que estavam da porta para fora... Fazia repertório para exames de final de ano ${ }^{11 "}$.

O que se desenha a partir de então é um deslocamento importante no que se refere ao modo convencional de encenar peças. Ao contrário dos diretores tradicionais, que criam os movimentos do palco segundo "marcas", após os atores decorarem suas falas $^{12}$, Boal põe em prática um tipo de ensaio em que o processo teatral parte do estudo do material feito em grupo.

\footnotetext{
${ }^{11}$ Boal, Augusto. Hamlet e o Filho do Padeiro. Rio de Janeiro: Editora Record, 2000, p. 153

${ }^{12} \mathrm{Um}$ exemplo disso se encontra na maneira mais freqüente de ensaio no TBC: "O método de Celi implicava, primeiro, "leituras de mesa", momento em que os atores liam seus textos até atingir as inflexões desejadas pelo diretor. Depois, passavam a decorar os papéis para, por fim, fazer os ensaios e as marcações das cenas". Prado, Luíz André do. Cacilda Becker, Fúria Santa. São Paulo: Geração Editorial, 2002, p. 293.
} 
Essa exigência formativa, frequente em tantos outros trabalhos experimentais, não era só impulsionada pela história acadêmica de Boal, mas vinha também como uma necessidade provocada pelo novo formato do palco do Arena, que não tolerava a velha empostação teatral e pedia uma outra forma de representar. Boal percebia que o trato específico com aquela teatralidade impunha a pesquisa sobre uma nova atuação, que deveria partir da reflexão sobre possibilidades diferentes de trânsito entre palco e platéia.

No Arena, Boal não estava sozinho nessa tendência à experimentação laboratorial. A origem do Teatro de Arena liga-se a uma nova prática teatral e acadêmica, já que seus fundadores José Renato, Emílio Fontana, Geraldo Matheus e Sérgio Sampaio, eram oriundos das primeiras turmas da Escola de Arte Dramática (EAD), o que muito os influenciou na elaboração dessa nova concepção de teatro e de encenação ${ }^{13}$.

Enquanto Boal vinha de uma experiência de aprendizado técnico, segundo o modelo artístico do playwriting norte-americano, essencialmente dramático, Guarnieri e Vianinha traziam a vivência no Partido Comunista e já procuravam uma arte capaz de participar dos debates políticos da época. Ainda que seja difícil medir o grau da influência de Ruggero Jacobbi, não há dúvida que foi uma das presenças críticas mais importantes na politização do trabalho do Arena. Suas reflexões sobre o nacionalpopular e admiração pelo sentido anti-ideológico e épico das formas clássicas do

\footnotetext{
13 "A aventura do Teatro de Arena começou na Escola de Arte Dramática de São Paulo... Não fosse a EAD um laboratório experimental, em que se encenaram no Brasil, pela primeira vez, nomes da importância de Brecht, lonesco, Beckett e muitos outros, dificilmente se entenderia ter ela estimulado a pesquisa que pôs em xeque a orientação do TBC". Magaldi, Sábato. Um Palco Brasileiro. O Arena de São Paulo. São Paulo: Editora Brasiliense, 1984, p. 10
} 
"teatro do povo", foram decisivas na guinada teorizante ocorrida no Arena: era preciso trabalhar, segundo o pensamento de Jacobbi $^{14}$, na perspectiva da interação entre estética e política, como sugere essa observação do biógrafo de Vianinha, Dênis de Moraes, a respeito da experiência anterior do Teatro Paulista do Estudante:

"Vianinha e Guarnieri entrosaram-se com Ruggero Jacobbi. O mais comprometido dos encenadores contratados pelo TBC, Ruggero pensava em agrupar estudantes numa proposta de discussão dos problemas sociais através do teatro... O encenador italiano convenceu Vianinha e Guarnieri a retomarem as leituras interrompidas pela militância, enfatizando a necessidade de uma boa formação cultural". ${ }^{15}$

Foi do sentido produtivo que assumiu essa tensão entre influências e desejos artísticos (que só virá a "explodir" mais tarde), mediada pela capacidade organizacional e agregadora de José Renato, que nasceu o projeto de trabalho inovador no Teatro de Arena. Coube a Boal, por sua disposição intelectual e prática, a tarefa de catalisador formativo de uma pesquisa artística que intensificava seu diálogo com os movimentos históricos e o sentimento político mais crítico da época. Os cursos livres ministrados por Boal, em que difundia sua experiência de aprendizado nos EUA, se tornariam o lugar de encontro laboratorial das diferentes visões sobre a arte que estavam em jogo no Arena.

\footnotetext{
${ }^{14}$ Nos parece que a influência de Jacobbi no moderno teatro nacional é uma história ainda a ser contada. Para uma aproximação com suas idéias ver: Vanucci, Alesandra ( org.). Crítica da Razão Teatral. O Teatro no Brasil visto por Ruggero Jacobbi. São Paulo: Perspectiva, 2005 e Raulino, Berenice. Ruggero Jacobbi. Presença Italiana no Teatro Brasileiro, São Paulo: Perspectiva, 2002.

${ }^{15}$ Moraes, Dênis de. Vianinha, Cúmplice da Paixão. Rio de Janeiro: Record, 2000, pp. 52, 53.
} 


\section{Os primeiros laboratórios}

A história do Seminário de Dramaturgia do Arena não pode ser compreendida sem que seja examinado o anterior trabalho laboratorial de atuação realizado em paralelo ao curso de dramaturgia, ambos ministrados por Boal a partir do ano de 1956. $\mathrm{Na}$ forma de um curso aberto à classe teatral, se instaurava aí uma primeira tentativa de sistematização dos estudos teatrais unindo a prática e a teoria. Como já mencionado, a prática da arena cênica exigia uma mudança de estilo de atuação: mais íntimo, realista, diferente da empostação frequente no conjunto do teatro da época. Esse processo de crítica à atuação retórica já estava em curso no próprio TBC quando a estilização dos atores do velho profissionalismo (como Procópio Ferreira e Jaime Costa) foi posta em xeque. O crítico Décio de Almeida Prado comentou esse processo:

"O corte histórico revelou-se tão abrupto que cindiu os atores em dois blocos exclusivos. Os elencos egressos do amadorismo não admitiam atores com mais de trinta anos - não por intolerância geracional, embora esta também existisse, mas por incompatibilidade de métodos e estilos. A quem se habituara a meses de ensaio, a presença do ponto, mais do que uma inutilidade, afigurava-se um estorvo. As falas tinham que vir de dentro, com as inflexões ditadas pela convicção interior. Já os atores como Jaime Costa e Procópio Ferreira, não obstante a longa prática, ou talvez por causa dela... não se sentiam seguros no palco sem aquela voz sussurrante que garantia a continuidade do espetáculo". ${ }^{16}$.

\footnotetext{
${ }^{16}$ Prado, Décio de Almeida. O Teatro Brasileiro Moderno. São Paulo: Perspectiva, 2008, p. 48.
} 
Essa maneira de representar trazida pelo TBC e que até então configurava-se como uma grande novidade, estava sendo, ela própria, rechaçada pelos integrantes do Arena. O enfrentamento situa-se dentro de um processo que já ocorria há alguns anos e que cada vez mais explicitava o embate entre a nova e a antiga visão sobre a forma apropriada de atuação em um teatro que se modernizava a passos largos. O seguinte depoimento de Flávio Migliaccio esclarece o caso:

"Quando eu comecei no Teatro de Arena, em 1954, se representava de uma forma mais empostada. A gente, inclusive, gozava um pouco os atores antigos do Teatro Brasileiro de Comédia (TBC), aqueles teatrões da Dulcina de Moraes e do Odilon de Azevedo. Era um erro gozar, mas a gente gozava. Os atores dessas companhias representavam assim: "Ah! Honesto lago, se não fosse o amor que a Desdêmona consagrou..." E o que fez o Teatro de Arena? O Teatro de Arena falou: "Vai ser tudo menor, porque o Teatro de Arena é pequeno e a gente não pode gritar. Vamos pegar temas brasileiros, interpretações brasileiras, tipos brasileiros". ${ }^{17}$

Essa característica do Teatro de Arena de exigir uma maneira mais comedida e intimista de atuação - que depois se associa a uma imagem de "atuação brasileira" leva seus integrantes a uma busca, de qualquer modo crítica, por novas ferramentas de interpretação.

É no Laboratório de Interpretação que Boal dá os primeiros passos para sistematizar uma técnica de atuação. Para isso, ele se vale dos exercícios que havia

\footnotetext{
${ }^{17}$ Migliaccio, Flávio. In www.memoriaglobo.com.br
} 
aprendido ao observar as aulas para atores no Actor's Studio, onde eram utilizadas técnicas desenvolvidas pelo diretor russo Constantin Stanislavski, tal como transmitidas por alguns de seus discípulos e reelaboradas por Elia Kazan e Lee Strasberg ${ }^{18}$.

Com a implantação do Laboratório de Interpretação, o elenco do Arena entra na lógica da pesquisa do teatro laboratorial que tinha surgido com força no início do século XX, em especial na Rússia e na Alemanha.

Em sua autobiografia Minha Vida na Arte, Stanislavski comenta a fundação, após os primeiros anos do Teatro de Arte de Moscou, do Estúdio da Rua Povarskaia, em 1905, feito em parceria com seu mais célebre aluno, Meyerhold. Sua procura, na época, de um lugar de trabalho descolado da companhia principal, permite compreender de que maneira o conceito de experimentação em estúdio se tornaria central no teatro moderno. Somente fora da lógica dos resultados e dos produtos teatrais, em conexão com a liberdade produtiva do amadorismo, as primeiras conquistas do Teatro de Arte poderiam ter continuidade:

"Como e onde iríamos realizar as novas iniciativas? Não havia lugar para elas num teatro que dava espetáculos diários, onde havia obrigações complicadas e um orçamento rigorosamente calculado. Precisávamos de algum estabelecimento especial, que Vsevolod Emílovitch batizou acertadamente de

\footnotetext{
18 “O Actor's Studio foi fundado em Nova York por Elia Kazan, Cheryl Crawford e Robert Lewis, em 1947. As raízes do Actor's Studio remontam ao Group Theater (1931-1941), cujo trabalho foi inspirado pelas descobertas do atore diretor russo Constantin Stanislavski e seu melhor aluno Eugene Vakhtangov. O lendário Teatro de Arte de Moscou viajou à América em 1923. Quando terminou a turnê americana, vários membros ficaram e treinaram vários artistas, incluindo Lee Strasberg, Clurman Harold e Stella Adler, que viriam a formar o Group Theater, juntamente com Elia Kazan, Sanford Meisner e Robert Lewis. Estes artistas desenvolveram um trabalho baseado nos mestres russos e um novo tipo de atuação nasceu". In www.theactorsstudio.org
} 
Estúdio Teatral. Não era um teatro pronto nem uma escola para principiantes, mas um laboratório de experiências com artistas mais ou menos preparados" 19

A mesma necessidade de um afastamento das atribuições de um teatro com espetáculos diários e contas a pagar motiva Boal e os integrantes do Laboratório de Interpretação. Mas ali não havia a possibilidade de criar um laboratório independente.

Do ponto de vista produtivo, o Teatro de Arena foi concebido como uma alternativa ao caro sistema de empresa teatral mantida pelos teatros de então ${ }^{20}$. Para isso, assumiu um "modelo de associações culturais" 21 , que se mantinha graças a "sócios" (o próprio público), que compravam quotas e tinham direito à entrada nas peças. Esse modelo demandava a manutenção dos sócios para que o teatro funcionasse. O repertório, portanto, deveria interessar a eles, o que explica, de certo modo, as primeiras escolhas das peças ali encenadas, que pareciam querer captar o gosto médio dos interessados no chamado teatro moderno.

Com a implementação de uma atitude experimental, na qual todas as funções são intercambiáveis, incluindo as de administração (o aprofundamento desse modelo será progressivo, demandará muitas discussões, até à ruptura entre os fundadores do

\footnotetext{
${ }^{19}$ Stanislavski, Constantin. Mi Vida em El Arte, Buenos Aires: Ediciones Diaspora, 1954, p. 249

20 "Fundado pelo empresário italiano Franco Zampari, o TBC foi o primeiro grupo a basear a sua programação em pesquisa não apenas no campo cultural, mas também na área do consumo. Constatou que São Paulo oferecia um campo extenso para a atividade artística, procurando, entre outras coisas, considerar o teatro como uma mercadoria para o público consumidor". Guzik, Alberto e Pereira, Maria Lúcia (org.) Dionysos. Especial TBC. Rio de Janeiro: Ministério da Educação e Cultura- Funarte. 1980, nota 6 p. 24.

${ }_{21}^{21}$ "Ao nível administrativo a companhia arquiteta um projeto financeiro bastante engenhoso, extraindo o modelo das associações culturais. A Companhia Teatro de Arena transforma-se na Sociedade Teatro de Arena. Há os sócios contribuintes... Internamente, a organização administrativa permanece fiel ao modelo de agrupamento. Na produção financeira do espetáculo os atores participam em igualdade de condições, mas com quantias proporcionais. A remuneração será feita por quotas, sem salários fixos". Lima, Mariângela Alves de. História das Idéias. In Dionysos, número 24. Rio de Janeiro: Ministério da Educação e Cultura- DAC. Funarte, 1978, pp. $34,35$.
} 
teatro alguns anos depois), a própria dinâmica capitalista da companhia teatral gera contradições entre os pontos de vista do capital e do trabalho. Essa mudança relativa do modelo de companhia teatral para o de um grupo acaba criando situações inusitadas, como a relatada pelo ator Nelson Xavier, abaixo:

\begin{abstract}
"Como fazíamos rodízio das funções administrativas, um dia era eu quem cuidava dos pagamentos. Tinha que pagar algo importante que não lembro mais o que era. Aí o Flávio Migliaccio disse que não tinha dinheiro para comer e decidimos votar para ver se daríamos o dinheiro para ele comer ou se pagaríamos a conta. Aí, decidimos pagar a conta! Vê se pode! Acabamos indo às vias de fato e o Flávio tirou o dinheiro de mim! (Risos) ${ }^{22 "}$.
\end{abstract}

A lógica da pesquisa laboratorial ajuda a instaurar, assim, uma problematização da estrutura geral do trabalho teatral do coletivo de artistas, e influencia cada vez mais todas as relações e decisões de seus integrantes.

Na medida em que a modernização de suas práticas não é apenas estética, mas de ordem produtiva, o Arena se torna um dos primeiros grupos brasileiros a totalizar em seu processo a crise proveniente de uma radicalização política que é a marca das experiências mais avançadas do teatro moderno ${ }^{23}$. Na mesma linha de

\footnotetext{
${ }^{22}$ Entrevista concedida pelo ator Nelson Xavier à presente autora. Rio de Janeiro, 25/10/2011.

${ }^{23}$ A pesquisadora Iná Camargo Costa reflete sobre o período: "Acreditamos que, a partir das experiências teatrais do século XIX, a reflexão não pode deixar de incluir os processos de encenação, por um lado, e as relações de produção, por outro. Sobretudo este segundo aspecto, na medida em que tem sido negligenciado mesmo quando a sua importância é reconhecida, e em função do qual a produção teatral moderna aponta para aspectos essencialmente políticos que progressivamente passarão a fazer parte de seu próprio conceito". A Produção Tardia do Teatro Moderno no Brasil. In Sinta o Drama. Rio de Janeiro: Editora Vozes, 1998, pp.12,13
} 
pensamento dos estúdios russos, parentes próximos dos Teatros Livres da França e Alemanha - a da experimentação e criação de um espaço de convivência estéticopolítica - é que Boal instaura o primeiro laboratório no Arena:

"Os atores tinham tomado gosto pelos exercícios de Stanislavski e pelos que eu inventava, já naquele tempo, e que me serviram de base para o Jogos para Atores e Não Atores. Nós institucionalizamos o Laboratório de Interpretação. De onde veio esse nome, laboratório? Creio que da praia vermelha. A química me ajudou, não apenas na escolha onomástica, mas na necessidade que sinto de sistematizar com precisão no rigor do trabalho. $O$ pensamento científico está por trás do que faço.... No Laboratório criávamos sentimento de fraternidade com atores que vinham de outras companhias. Tínhamos orgulho em falar de classe teatral, era como se falássemos de parcela importante da classe operária ${ }^{24 \prime}$.

Apesar da blague de Boal sobre a invenção do termo laboratório, atribuída a sua passagem pela faculdade de química, a idéia de um Teatro Estúdio ou Teatro Laboratório, tão central na experiência do modernismo teatral, ${ }^{25}$ encontrava, salvo engano, sua primeira formulação crítica no Brasil.

\footnotetext{
${ }^{24}$ Boal, Augusto. Hamlet e o Filho do Padeiro. Rio de Janeiro: Editora Record, 2000, p. 147.

${ }^{25}$ Sobre essa questão, o pesquisador do período Camilo Scandolara, faz a seguinte observação: "Os estúdios do Teatro de Arte de Moscou inserem-se em um movimento característico do processo de renovação teatral do início do século XX: o afastamento em relação aos centros da produção com o objetivo de reconstruir o ofício do ator e do diretor desde as suas bases. Partindo da constatação de que renovar o teatro implicava, antes de tudo, em criar uma pedagogia teatral sólida, Leopold Sulerjítski, Evguiêni Vakhtângov e Konstantin Stanislávski geraram espaços de experimentação nos quais a pedagogia era concebida como ato criativo, como atividade de invenção de possibilidades de teatro". Os Estúdios de Teatro de Arte de Moscou e a Formação da Pedagogia Teatral no Século XX. Dissertação de mestrado apresentada ao Curso de Artes do Instituto de Artes da UNICAMP, 2006, p. VI
} 
Essa tradição surgia na experiência brasileira por meio de uma necessidade formativa de um jovem grupo de artistas que se via motivado a repensar as categorias teatrais de seu trabalho, unindo pedagogia laboratorial e prática de espetáculos. Assim, um projeto estético se forma no sentido de um trabalho de arte mais igualitário, o que implica uma recusa aos padrões do sistema das estrelas de palco. Uma polêmica de Alfredo Mesquita, na Revista Teatro Brasileiro, com o ator Procópio Ferreira, ajuda a situar o sentido difícil da novidade que às duras penas o próprio TBC tentava implantar. Procópio havia qualificado o "teatro de equipe" como "teatro dos medíocres"26", ao que responde o fundador da Escola de Arte Dramática:

" "Que é hoje em dia a Comédie Française... se não um teatro de equipe? E a companhia de Barrault?... Nem Barrault é tido como um grande ator... mas sim por um grande diretor que encarna justamente o espírito do teatro de equipe. O T.N.P., considerado o melhor teatro da França, é também um teatro de equipe. E, passando da França à Inglaterra, o Old Vick, teatro de equipe... E qual, atualmente, a mais afamada companhia italiana se não a do Piccolo Teatro de Milão? Teatro de equipe. Também foi teatro de equipe aquele que a Bélgica nos mandou em 55. Sem falar nos Estados Unidos - não é essencialmente um teatro de grandes estrelas, mas de conjunto... E cremos que com tais exemplos demos a volta no que há de melhor no mundo em matéria de teatro. ${ }^{27 \prime \prime}$

\footnotetext{
26 "Não tenho culpa de destacar-me do elenco. A culpa não é minha, mas dos autores que fazem sempre papéis salientes nas peças. Aliás, não há teatro de equipe, teatro de equipe é slogan inventado pelos medíocres". Ferreira, Procópio. Revista Teatro Brasileiro. São Paulo: Editora Livraria Jaraguá LTDA, 1956, p. 6

${ }^{27}$ Mesquita, Alfredo. A Entrevista de Procópio in Revista Teatro Brasileiro. São Paulo: Editora Livraria Jaraguá LTDA, 1956, p. 29.
} 
Os laboratórios divulgados por Boal e pelo Teatro de Arena se tornam, em pouco tempo, um modelo de caminho coletivizante para o trabalho do ator no país. Mesmo os que preferiam métodos tradicionais de ensaio de mesa e marcação, eram obrigados a considerar a realidade da exigência da pesquisa. A qualidade notável dos espetáculos do grupo, ao mesmo tempo, confirmava a eficácia do método, o que parecia fazer dessa prática experimental quase uma obrigação à qual muitos reagiam, o que se vê na seguinte fala de Flávio Rangel:

"Eu fico pensando se está certa essa exigência do laboratório. Tenho impressão que é impor, a uma criatividade natural que os atores possam ter, uma linha que procure uma identidade entre eles. Acho que isso é perigoso. Então, o laboratório é uma coisa que fica a critério de cada ator. $O$ ator querendo, faz. É seu trabalho de casa. Eu nunca impus isso aos meus atores. ${ }^{228}$

Revela-se, portanto, nesse momento no Brasil, um "atraso acumulado" em relação à discussão estética internacional, que se tentava suprimir numa velocidade espantosa. Enquanto o teatro moderno europeu, após o movimento naturalista, já experimentara todo tipo de modificação da percepção do palco, tendo, inclusive, formulado conceitos novos em relação ao drama (sendo o caso mais radical o de Brecht), o Arena ainda lidava com a expectativa de conseguir pôr em prática um realismo dramático verdadeiro ${ }^{29}$, numa demanda quase naturalista. $O$ modelo formal, entretanto, entrava em contradição com as conquistas do trabalho teatral coletivizado,

\footnotetext{
${ }^{28}$ Rangel, Flávio. In Siqueira, José Rubens. Viver de Teatro - Uma Biografia de Flávio Rangel. São Paulo: Nova Alexandria, 1995. p. 246.

${ }^{29}$ Sobre o assunto ver: Costa, Iná Camargo. A Hora do Teatro Épico no Brasil. São Paulo: Editora Graal, 1996, pp. 38,39 .
} 
e com as expectativas ideológicas dos próprios integrantes mais politizados, o que pedia experimentação. Foi esse o lugar ocupado pelo Laboratório de Interpretação.

\section{Laboratório de Interpretação e o modelo do Actor's Studio}

A principal motivação para a implementação do Laboratório de Interpretação do Teatro de Arena foi a busca de uma representação realista de qualidade. Naquele primeiro momento, o conceito era utilizado por Boal em seu sentido mais genérico: realismo era uma linguagem por meio da qual os atores poderiam alcançar a "verdade física e emocional" de qualquer personagem, sem precisar explicitar a representação. Era preciso se afastar das estilizações do velho teatro. Para isso Boal busca auxílio nas técnicas aprendidas em sua passagem pelos EUA. É importante assinalar que em sua estada na Universidade de Colúmbia, como estudante de química, Boal foi ouvinte em algumas aulas do Actor's Studio, nas quais pôde apenas observar exercícios realizados ali pelos alunos ${ }^{30}$. A base desses exercícios, como se sabe, eram stanislavskianas, mas apenas seguindo as versões do chamado "sistema" difundidas por alguns de seus discípulos que emigraram da Rússia, tais como Richard Boleslavski ${ }^{31}$.

\footnotetext{
${ }^{30}$ É o próprio Boal quem comenta de que modo foi introduzido nas aulas: "Gassner conseguiu que eu fosse admitido em sessões do Actor's Studio, como ouvinte - melhor dito, vidente, pois via mais do que entendia". Boal, Augusto. Hamlet e o Filho Padeiro. Rio de Janeiro: Editora Record, 2000, pp. 126, 127

${ }^{31} \mathrm{Em}$ seu livro $A$ Arte do Ator, Boleslavski conceitua muitos dos preceitos que difundiu quando de sua estada nos EUA. Boleslavski, Richard. A Arte do Ator. São Paulo: Editora Perspectiva, 1992.
} 
Indo além desse modelo, Boal, no Brasil, passou a estudar diretamente a obra de Stanislavski. Ao fundar o Laboratório de Interpretação punha em prática pela primeira vez a síntese que pretendia entre as observações que vinha realizando e a teoria recebida dos intérpretes norte-americanos.

É com o Laboratório que nesse momento Boal assume uma "atitude científica perante o teatro,32 e passa a sistematizar sua prática. Grande parte dessa sistematização foi descrita, anos depois, no livro 200 Exercícios e Jogos para o Ator e o Não-ator com Vontade de Dizer Algo Através do Teatro ${ }^{33}$. Além de exercícios desenvolvidos pelo diretor e atores com quem trabalhava, utilizavam-se também de alguns já realizados por outros grupos e autores, que eram continuamente reelaborados. ${ }^{34}$

Para que melhor se entenda o funcionamento prático do Laboratório iremos comentar duas séries de exercícios ali realizadas: "exercícios gerais sem texto e ensaios de motivação com texto"35. Ambas ilustram bem o caminho que será tomado a seguir na pesquisa do Arena, e são minuciosamente descritas e comentadas pelo autor.

32 "Kusnet, Stanislavski e Brecht tinham em comum a atitude científica diante do teatro. Para eles a prática e a teoria não se separavam. Dedicaram-se à abordagem experimental, o velho e bom caminho da tentativa e do erro. Conheciam bem a diferença que faz um trabalho coletivo não alienado, em que os atores são donos dos meios de produção simbólica da cena e pensam e imaginam por conta e risco". Carvalho, Sérgio de. Ações Físicas segundo Stanislavski e Brecht In Introdução ao Teatro Dialético. São Paulo: Expressão Popular, 2009, p. 85

${ }^{33}$ Boal, Augusto. 200 Exercícios e Jogos para o Ator e o Não-Ator com Vontade de Dizer Algo Através do Teatro. Rio de Janeiro: Civilização Brasileira, 1982.

34 "O propósito deste livro é sistematizar todos os exercícios utilizados pelo Teatro de Arena de São Paulo (Brasil)... Também se incluem exercícios inventados por Stanislavski e Brecht (as nossas principais fontes em todas as nossas etapas) e por outros diretores e grupos, especialmente latino-americanos. Nestes casos, explicamos os exercícios tal como eram praticados no nosso teatro, e não nas suas versões originais". Boal, Augusto. 200 Exercícios e Jogos para o Ator e o Não-Ator com Vontade de Dizer Algo Através do Teatro. Rio de Janeiro: Editora Civilização Brasileira, 1982, p. 10

${ }^{35}$ Boal, Augusto. 200 Exercícios e Jogos para o Ator e o Não-Ator com Vontade de Dizer Algo Através do Teatro. Rio de Janeiro: Editora Civilização Brasileira, 1982, pp. 108 a 120 
Os "exercícios gerais sem texto" são basicamente compostos por improvisações. Mas as improvisações não estão diretamente relacionadas a um texto ou personagem que será desenvolvido pelos atores posteriormente ${ }^{36}$. A improvisação nesse caso visa despertar no ator a sua "vontade dominante". E não a da personagem. Essa "vontade dominante" será o resultado da luta entre, pelo menos uma vontade e uma contravontade, a qual determinará um conflito interno. Mais do que desenvolver em um ator essa dinâmica, a improvisação pretende desenvolver essa capacidade na inter-relação dos atores. Assim, cada "vontade dominante" de um ator deve entrar em relação com a do outro ator e formar um conflito externo, objetivo. A partir daí será posto em movimento um "sistema conflituoso" que terá "variações quantitativas e qualitativas em seu interior".

A terminologia dialética sobre "quantidade e qualidade" aparece aqui, o que faz imaginar que (mesmo se tratando de um texto posterior), a categoria já estivesse em jogo naquela primeira fase. O importante, por enquanto, é que Boal elabora um sistema de atuação que não tem como principal meta o estabelecimento de uma maneira específica de criação de personagens, mas a tentativa de desvendar o que move o ator em cena. Mais do que buscar no ator a sua capacidade de "ativar uma emoção", Boal tenta, com a improvisação, desenvolver neste exercício sua capacidade de relacionarse com o outro ator.

\footnotetext{
${ }^{36}$ Boal utiliza-se da improvisação segundo a lógica de trabalho proposta por Stanislavski, como descrita por Sérgio de Carvalho: "Como o trabalho de improvisação visa ao estudo da lógica das situações, seu pressuposto conceitual é de que não são as emoções que movem um ator em cena. Ao contrário, são suas ações (psicofísicas e verbais) que geram as emoções da cena". Ações Físicas segundo Stanislavski e Brecht In Introdução ao Teatro Dialético. São Paulo: Expressão Popular, 2009, p. 81
} 
E, para chegar a isso, o ator deveria conseguir se relacionar ainda com o "outro de si mesmo". Essa seria a chave para que os atores conseguissem chegar a uma interpretação que os pusesse em relação com o outro ator. Anos mais tarde, em suas memórias, Boal descreve a importância que tinha para ele a descoberta desse jogo entre "um e outro" na construção dos personagens e da peça como um todo:

"... eu insistia em que atores deveriam vagar e navegar num mar de significados possiveis, devanear: fazer com que o desejo de ser um... e não o outro, provocasse a emoção que os levaria à forma justa: idéia - emoção forma: a essencial tríade! Queremos ser um e não outro. Os atores deveriam pensar um e outro com amplitude e não singularizar um dos sentidos possiveis, reduzindo-os a só isto ou só aquilo"37.

Essa descoberta hegeliana do "outro de si" do ator é um caminho fundamental ao sistema de interpretação proposto por Boal. Para ele, o conflito, fundado num intraconflito, é a base da interpretação. O jogo conflituoso se dá em um primeiro momento dentro do próprio ator que, na sua luta interna, deve descobrir o "outro de si mesmo" para ter condição de interpretar a inter-relação com o outro ator. Aquele com que contracena deve fazer o mesmo e assim, sucessivamente, cria-se um movimento conjunto, um processo de intercâmbios. Esse estar em movimento é que permitirá que o ator não fique imerso apenas na sua subjetividade, o que seria paralisante.

Talvez o que garantiu que sua experimentação não tenha sucumbido ao modelo mais sentimentalista do Actor's Studio tenha sido, no fundo, o desejo de seguir de

\footnotetext{
${ }^{37}$ Boal, Augusto. Hamlet e o Filho do Padeiro. Rio de Janeiro: Editora Record, 2000, p. 145.
} 
perto os passos dinâmicos de Stanislavski ${ }^{38}$, que muito mais do que um sistema fechado, procurou princípios de trabalho objetivadores do processo de criação artística, não tendo nunca se assentado em conquistas fixas, numa clara exposição de um caminho experimental na arte ${ }^{39}$. Anos depois Boal seria capaz de criticar o método de seus professores norte-americanos, explicitando sua busca por uma interpretação própria:

"Essa hipertrofia da subjetividade era visível e notável nos atores saídos do Actor's Studio. Todos pensavam tanto, imaginavam tantas coisas para cada frase, para cada palavra que diziam, que a sua interpretação era extraordinariamente lenta e cheia de ações $e$ atividades laterais $e$ secundárias... Esse tipo de interpretação sobrecarregada de emoção chegava mesmo ao extremo de mudar o estilo da peça que de realista tornava-se expressionista: o tempo real era o tempo subjetivo do personagem e não o tempo objetivo da inter-relação de personagens. Ao compreender isto, compreendemos igualmente que a criação do ator deve ser, fundamentalmente, a criação de inter-relação com os outros." 40

\footnotetext{
${ }^{38}$ Boal assume em muitos de seus escritos a profunda influência que sofria da pesquisa do diretor russo: "A melhor maneira de ensaiar seria, desde o primeiro dia, praticar Stanislavski. Expliquei como seria o trabalho, pedi que estudassem os primeiros capítulos da Preparação do Ator, que começaríamos a experimentar no primeiro ensaio... Fui para casa reler anotações sobre o Actor's Studio, rever rabiscos, nos livros do mestre russo. Stanislavski foi, desde minha estréia profissional, setembro de 1956, e até meu futuro, minha referência como diretor". Boal, Augusto. Hamlet e o Filho do Padeiro. Rio de Janeiro: Editora Record, 2000, p.141.

39 "Assim, o mais correto, em se tratando de Stanislavski é falarmos em "princípios" de trabalho. Não em método. São caminhos que se refizeram dentro de um projeto totalizante, e que não se completaram como sistema. É uma obra, como costumam ser as grandes, que pede uma espécie de reescritura por parte de cada leitor". Carvalho, Sérgio de. Ações Físicas segundo Stanislavski e Brecht In Introdução ao Teatro Dialético. São Paulo: Expressão Popular, 2009, p. 82

40 Boal, Augusto. 200 Exercícios e Jogos para o Ator e o não-ator Com Vontade de dizer algo através do Teatro. Rio de Janeiro: Civilização Brasileira, 1982, pp. 47, 48
} 
É quase certo que foi a prática laboratorial coletivizada do Arena que obrigou Boal a deslocar a ênfase dos aspectos internos da atuação para uma reflexão mais ampla sobre o sentido dos condicionamentos. É como se ele passasse, pela prática com atores e pela leitura da fonte direta de Stanislavski, para uma visão relacional da atuação. Já não importam mais os estados internos verdadeiros do ator, e sim sua busca por uma interação real com o outro.

\section{Atuação relacional}

Num segundo momento da pesquisa, Boal percebe que não é possível apenas lidar com a emoção dos atores, mas faz-se necessário racionalizá-la, também no sentido de uma dialética da relação com o outro, rumo a uma objetivação do trabalho dos atores. Boal passa a se interessar pelo "fluxo das emoções" ao constatar que não há como "sentir" sem que esse mesmo sentimento gere um pensamento, que gera um novo sentimento e assim sucessivamente. Essas observações indicam que passa a ser necessária, para ele, a incorporação metodológica da auto-crítica. Surge, de modo determinante, o projeto de organização do trabalho da atuação segundo uma ferramenta teórica que seria fundamental para o conjunto de sua visão do teatro: a dialética.

Importa destacar que Boal, assim como Stanislasvki, passa da procura por "estados emotivos" à procura por "fluxos vivenciais", que nascem do trato concreto com o outro. 
Para isso será necessário que os atores tenham presente em cena uma posição crítica em face do diálogo. Precisam colocar em movimento seu pensamento sobre as emoções, pois só assim elas deixarão de ser algo isolado para transformarem-se em emoções ativas que gerarão novos pensamentos criadores. Tudo isso implica uma dinâmica relacional, como destaca Boal:

“... A criação do ator deve ser, fundamentalmente, a criação de interrelação com os outros. Antes criávamos lagoas de emoção, profundas lagoas emocionais, mas a empatia, a ligação emocional personagem-espectador, é necessariamente dinâmica. Um excesso de... subjetividade pode levar à ruptura das relações entre as personagens e a criação de lagoas de emoção isoladas. Mas nós precisamos criar rios em movimento dinâmico e não mera exibição de emoção. Teatro é conflito, luta, movimento, transformação e não simples exibição de estados de alma. É verbo, e não simples adjetivo" ${ }^{41}$

Será, então, na inter-relação concreta que Boal achará a síntese para a sua procura da interpretação realista. O corpo do ator não fica mais preso a si mesmo, à sua própria emoção, mas será no enfrentamento com o outro ator (e com o outro de si mesmo - a personagem) que esse corpo ganha alteridade e se "desmecaniza". O grande ator não é aquele que se destaca do restante do elenco, mas sim o que aprofunda seu diálogo com outro. A busca é pela unidade de linguagem cênica, que ocorrerá por meio da atuação dialética.

\section{Dialética da atuação}

\footnotetext{
${ }^{41}$ Boal, Augusto 200 Exercícios e Jogos para o Ator e o Não-Ator com Vontade de Dizer Algo Através do Teatro. Rio de Janeiro: Civilização Brasileira, 1982, pp. 47,48
} 
O Laboratório de Interpretação inaugura o encaminhamento metodológico das pesquisas de Boal e do Arena. É ali que, pela primeira vez no grupo, uma visão dialética do trabalho artístico passa a ser praticada. É significativo que os termos de Boal sejam muito semelhantes aos utilizados pelo filósofo alemão Hegel, que sistematizou o estudo sobre a dialética moderna. A proximidade das idéias do filósofo fica ainda mais clara quando Boal faz seu resumo do que seria um esquema ideal de representação:

"Idéia central da peça determinando a idéia central da personagem, traduzida em termos de vontade que se dialetizava (vontade e contra vontade); do conflito de vontades nascia a ação (variação quantitativa e qualitativa) ${ }^{42 "}$.

Não apenas stanislavskiano, o conceito de "vontade e contra vontade" se torna hegeliano na versão do Arena ao servir a um movimento incessante das idéias, sentimentos e atitudes do ator a partir da procura constante das alteridades. Será essa mesma visão que embasará, em seguida, a pesquisa do Teatro de Arena na área de dramaturgia, com a fundação do curso de dramaturgia.

\footnotetext{
${ }^{42}$ Augusto Boal. 200 Exercícios e Jogos para o Ator e o Não-Ator com Vontade de Dizer Algo Através do Teatro. Rio de Janeiro: Civilização Brasileira, 1982, p. 57
} 


\section{Capítulo 2}

\section{Dramaturgia Laboratorial}

O Laboratório de Interpretação fundado por Augusto Boal em 1956, instaura uma nova fase no Teatro de Arena, a partir da qual o foco central do trabalho do grupo não

é mais apenas levar ao palco peças do teatro moderno, mas também pesquisar a encenação brasileira a partir de uma lógica laboratorial, o que incluía a ênfase no processo de ensaios e não somente em seu resultado final.

Assim, o tempo de preparo, os exercícios de pesquisa e o desenvolvimento da relação entre os atores passam a ser expandidos. No entanto, o Teatro de Arena não deixava de ser uma pequena empresa teatral que necessitava de capital para 0 pagamento de seus integrantes, de sua sede fixa e dos outros custos de manutenção de uma equipe. De um certo ponto de vista, a prática laboratorial - que vai extrapolar o âmbito da atuação e gerar uma análoga pesquisa na dramaturgia - pode ser lida como expressão de uma crise do modelo produtivo do Arena, iniciada, a rigor, um ano antes, com a incorporação do Teatro Paulista do Estudante (TPE).

\section{Crise do modelo produtivo}

No que se refere à sua situação produtiva, o Arena nunca foi exatamente uma empresa convencional. Desde sua fundação, José Renato procurou implantar um 
modelo alternativo de gestão em que os atores, sem vínculo empregatício convencional, partilhavam das receitas de seu trabalho. Segundo informação da crítica e pesquisadora Mariangêla Alves de Lima, "os atores participam em igualdade de condições mas com quantias proporcionais. A remuneração será feita por quotas, sem salário fixo ${ }^{43 "}$.

Como já mencionado, a própria manutenção do teatro não dependia só das bilheterias, na medida em que se tentou utilizar o sistema de sócios contribuintes, em que o público interessado ajudava na manutenção da equipe durante a produção de um repertório. Esse modelo, porém, mostrou-se inviável, pela flutuação das verbas, do público e do próprio elenco. ${ }^{44}$ Por conta disso, na época da chegada de Augusto Boal ao Arena, a companhia já tinha retornado a um modelo administrativo mais "ortodoxo", com estrutura hierarquizada, sendo as decisões tomadas apenas pelo dono e diretor do teatro, José Renato. O dramaturgo Gianfrancesco Guarnieri comenta anos depois:

"A gente não falava com o Zé Renato de igual para igual, não. Zé Renato era o diretor do teatro. A gente dava umas sugestõezinhas e tal, mas existia uma hierarquia, um certo autoritarismo dentro do Teatro de Arena. Aliás o Zé Renato ensaiava com uma vara. Aí chega o Boal ... formou-se então

\footnotetext{
${ }^{43}$ Lima, mariângela Alves de. História das Idéias. In Dionysos. São Paulo: Ministério da Educação e Cultura- Funarte, 1978, p. 35.

${ }^{44}$ É Mariângela Alves de Lima quem comenta o processo: "Enquanto a atividade cultural se desenvolve de acordo com as previsões, na organização administrativa a companhia sofre constantes modificações. $O$ sistema de quotas para remuneração do elenco torna-se inadequado em face das constantes desistências e renovações... Na produção, a unidade de objetivos vai se esfumaçando na medida em que a equipe se transforma. Utiliza-se cada vez mais uma divisão hierarquizada do trabalho, modo de produção habitual do nosso teatro... Em dois anos a companhia atravessou reformulações administrativas e de pessoal praticamente depois de cada espetáculo. Havia uma célula básica de sustentação que garantia a continuidade ideológica do projeto. Mas, ainda assim, o desejo de conservar um grupo unido e um elenco permanente para todas as produções torna-se inviável". Lima, Mariângela Alves de, História das Idéias. In Dionysos. Rio de Janeiro: Ministério da Educação e Cultura- Funarte, 1978, p. 38
} 
essa patota, esse conjunto feito lá dentro e nosso contato passou a ser de 24 horas por dia...A discussão era desde a hora de se encontrar até cair de sono... ${ }^{45 \prime \prime}$.

A prática laboratorial e a tendência ao debate constante gerada por ela, movimento em pleno curso em 1956, parece ter contribuído para o aprofundamento das contradições de uma companhia que cada vez mais se comportava como um grupo, em que as decisões centralizadas passaram a ser vistas como um problema a ser superado.

Não é por acaso que o desenvolvimento da pesquisa laboratorial dos atores coincide com as tentativas de um novo modelo de gestão, em que as funções administrativas do teatro passam a ser divididas entre os integrantes do grupo, numa espécie de rodízio ${ }^{46}$. Essas tentativas só confirmavam o momento de crise em que 0 velho Teatro de Arena dava lugar a um novo coletivo de artistas.

\section{Crise estético-política}

O processo de transformações críticas do Arena teve início antes da entrada de Augusto Boal no grupo. Foi certamente em 1955, quando o Arena se funde ao Teatro Paulista do Estudante (TPE), que uma mudança em relação à concepção de

\footnotetext{
${ }^{45}$ Guarnieri, Gianfrancesco In Depoimentos V. Rio de Janeiro: MEC. SNT, 1981, p. 85

${ }^{46}$ Sobre a questão ver nota 19.
} 
modernização passou a entrar nos debates da equipe. O TPE era um grupo que desde a sua origem tinha como principal meta a realização de um teatro político e de viés nacional-popular. E foi Ruggero Jacobbi, um de seus principais idealizadores, quem melhor estabeleceu as diretrizes de um programa que depois seria encampado pelo Arena:

“... há muitos anos estamos lutando pela consituição do TPE, isto é, um grupo de amadores capazes de realizar um trabalho não apenas "teatral" (no sentido da descoberta de vocações ou talentos), mas sim "cultural"e "popular" fazendo de seu repertório um mostruário de inéditos e de curiosidades literárias dignas de estudos ou de divulgação, e realizando um esforço positivo no sentido de conquistar paulatinamente várias platéias, mais ou menos afastadas do teatro "oficial", começando pelo próprio público estudantil.",47

Não foi a clareza ideológica, entretanto, que estimulou a junção das equipes. Nem só o empenho de Jacobbi. Um dos motivos que levou o Arena a incorporar o TPE foi a crise financeira. Os integrantes amadores do TPE vieram para reforçar o elenco em dissolução do Arena, companhia que tinha problemas em manter seu quadro de atores por conta das oscilações de caixa que sofria ${ }^{48}$.

\footnotetext{
${ }^{47}$ Jacobbi, Ruggero. A Rua da Igreja, In Vanucci, Alesandra ( org.). Crítica da Razão Teatral. O Teatro no Brasil visto por Ruggero Jacobbi, São Paulo: Perspectiva, 2005, p. 60

${ }^{48}$ Quem comenta a questão é Guarnieri em uma entrevista dada anos depois a Fernando Peixoto: "FP- Qual o interesse do Arena na fusão? GG- Inicialmente econômico. No primeiro estágio foi isso. Teria mais pessoas, algumas que já haviam revelado qualidade no trabalho, e por um preço irrisório. Reforçava o elenco permanente, que começava a ter problemas, a gente ficava de suporting cast" Guarnieri, Gianfrancesco. Entrevista com Gianfrancesco Guanieri In Peixoto, FernandoTeatro em Movimento. São Paulo: HUCITEC, 1989, p. 49
} 
A incorporação, no mesmo passo que solucionava uma dificuldade produtiva, abria uma crise estético-política, de início pouco visível, mas que se desenvolveria ao longo dos anos seguintes, com efeitos variados. O TPE não entrava no Arena apenas com atores em busca de profissionalização, mas com artistas politizados e militantes, influenciados pela visão crítica de um grande intelectual favorável ao nacional-popular como Jacobbi e pela influência relativa do Partido Comunista. A eclosão da tensão só ocorrerá, entretanto, com a entrada de Boal, cuja interferência nas técnicas de trabalho acabam por expor as diferenças entre as visões sobre a necessária modernização da cena teatral, como afirma Guarnieri anos depois:

"E aí chega o Boal... já nessa época havia uma certa divisão dentro do Arena, uma certa contradição. Já havia elementos mais velhos que não afinavam com nossas idéias, e a gente não compreendia bem porque eles ainda continuavam lá. A vinda do Boal reforçou nossa posição. Ele preferiu trabalhar com o nosso grupo, com os mais jovens". 49

A escolha do grupo "mais jovem", como o qualifica Guarnieri, indica o rumo politizado que o Arena adota a partir de então. Já na primeira incursão de Boal como diretor, em 1956, quando da montagem da peça Ratos e Homens, de Steinbeck, as forças "mais jovens" do Arena procuram seu lugar no pequeno palco da rua Teodoro Baima. O texto, um drama social, auxiliou o grupo a enveredar pela linha de pesquisa laboratorial e realista. Predominava nesta fase, entretanto, o sentido técnico dos debates, como afirma Guarnieri:

${ }^{49}$ Guarnieri, Gianfrancesco In Depoimentos V. Rio de Janeiro: MEC. SNT, 1981, pp. 49, 50 
"A proposta dele (Boal) foi montar Ratos e Homens, de Steinbeck, que nos permitiria fazer um trabalho de aprofundamento em nível de interpretação. Era uma peça realista, que dava elementos para este trabalho de laboratório e aprofundamento. Foi aí que começamos a definir novas linhas de trabalho para o Arena. O espetáculo nos permitiu pôr em questão tudo o que era feito antes. Questionava o método de trabalho. Aprofundou-se uma discussão e se encontrou uma metodologia para examinar criticamente o que vinha sendo feito. O que era antes encarado apenas de maneira subjetiva, passou a ser alvo de uma investigação objetiva, não intuitiva, mas coerente $e$ mais organizada ${ }^{50 "}$.

Em mais de uma ocasião, Guarnieri ressalta o quanto a primeira direção de Boal auxiliou na transformação metodológica do trabalho do grupo. O texto era estudado na sua relação dialética com a encenação, o que implicava experimentação por parte dos atores e do diretor. Não há mais espaço para o chamado "trabalho de mesa" nos moldes do $\mathrm{TBC}^{51}$, em que os atores estudavam o texto e o decoravam já conhecendo as definições de intenção enunciadas pelo diretor. Para que a pesquisa se aprofundasse, era necessária uma maior autonomia dos integrantes do Arena em relação à dramaturgia.

\footnotetext{
50 Guarnieri, Gianfrancesco In Depoimentos V. Rio de Janeiro: MEC. SNT, 1981, p. 50

${ }^{51}$ Essa dinâmica de trabalho é descrita pela atriz do TBC, Elizabeth Henreid: "Em primeiro, o diretor lia a peça. Todo mundo em volta da mesa lia a peça. Depois se fazia a leitura ainda sem distribuição de papéis. No terceiro dia, fixavam-se as personagens de cada um. E ai havia um trabalho de mesa bastante grande, quer dizer, se dissecavam os personagens na mesa. Nós tínhamos o ensaio de mesa pelo menos durante três semanas em geral, você até saía da mesa com o texto mais ou menos decorado, de tanto ler e reler e buscar e sondar. Aí então começava a marcação. A marcação em geral já estava esquematizada, de modo que o primeiro ato se marcava em dois ou três dias, o segundo idem, quer dizer, num espaço de uma semana a peça já estava toda marcada. A partir de então, começava apenas a burilação a respeito do texto, porque o trabalho grosso era feito na mesa. Quando você saía da mesa, já estava com tudo bastante firme para começar a trabalhar". In Silva, Armando Sérgio da. Uma Oficina de Atores. A Escola de Arte Dramática de Alfredo Mesquita. São Paulo: EDUSP, 1989, p. 117.
} 
O chamado Curso de Dramaturgia do Arena, que tem início em 1956, como uma formação complementar aos exercícios dos laboratórios de atuação, nasce dessa necessidade de compreensão técnica: era preciso que os atores também fossem dramaturgos num trabalho desse tipo. Era como se a especialização atrapalhasse 0 diálogo com padrões modernos ainda pouco formulados porque sempre abertos. Assim, são os próprios atores que propõem a Boal que formule um curso em que divida com toda a equipe seu aprendizado técnico em dramaturgia na Universidade de Colúmbia $^{52}$. É desse modo que nasce o primeiro curso de dramaturgia do Arena, aberto ao público, e que, por conta do grande afluxo de interessados, será repetido no ano seguinte. ${ }^{53}$

\section{Crise de repertório}

O estudo das chamadas "leis da dramaturgia" que Boal procurava fazer em seu curso resultava de seu contato pessoal com o trabalho do teórico norte-americano John Gassner. Sem entrar no mérito da universalidade ou particularidade desse modelo de drama, importa assinalar que mesmo esse estudo aparecia no Arena já modificado em relação a suas referências acadêmicas, na medida em que era uma consequência direta do Laboratório de Interpretação e servia para ajudar a ler textos que eram

\footnotetext{
52 É Boal quem narra o fato: "O elenco me pediu para contar como eram as aulas do Gassner. Queriam que eu fizesse um curso de dramaturgia, aberto ao público. Achei a idéia boa." Boal, Augusto. Hamlet e o Filho do Padeiro. Rio de janeiro: Editora Record, 2000, p. 147.

53 "No ano seguinte, 1957, organizamos outro curso de dramaturgia, aberto." Boal, Augusto. Hamlet e o Filho do Padeiro. Rio de janeiro: Editora Record, 2000, pp. 148, 149.
} 
adaptados ao espaço da pequena companhia. Um drama como aquele de Steinbeck encenado em 1956 já se confrontava com os desejos de uma jovem equipe politizada e interessada em se apropriar de referências mundiais para produzir sua arte local.

Em formato de conferências ministradas por Boal, o Curso de Dramaturgia recebia, também, a influência dos alunos de fora do Arena. Sua razão fundamental, entretanto, era instrumentalizar o próprio elenco, o que justifica a predominância dos debates sobre aspectos técnicos da escrita teatral, como enfatiza Boal em suas memórias:

"Durante semanas, reuniam-se cinquenta pessoas assíduas e eu dava aulas mostrando que as leis em dramaturgia são instrumentos de trabalho, para serem utilizadas, não obedecidas. Leis extraídas de obras-primas, Sófocles, Shakespeare, Moliére. Se quiser, use; se não, corra riscos... ${ }^{54 ”}$

O fato notável é que ali se iniciava um dos mais importantes ciclos de pedagogia dramatúrgica do pais. Em sua forma inicial, diferente do Seminário posterior, as aulas eram expositivas, seguidas de debates que se estendiam à pesquisa laboratorial do grupo.

Tudo indica que no Curso os temas técnicos eram priorizados em relação aos debates temáticos, ainda que os jovens artistas oriundos do TPE estivessem pressionando o encaminhamento da pesquisa para assuntos do país numa perspectiva popular. Visava-se o aprendizado das supostas leis gerais do drama universal,

\footnotetext{
${ }^{54}$ Boal, Augusto. Hamlet e o Filho do Padeiro. Rio de Janeiro: Editora Record, 2000, p. 148.
} 
descritas numa perspectiva abrangente o suficiente para permitir que certos procedimentos muito gerais da dialética dramática pudessem ser observados em textos de épocas diversas.

Boal trata em suas conferências, ainda, da ligação dialética entre a atuação e os estudos de dramaturgia, dando ênfase à interação entre a "estrutura teatral" e à "dinâmica dramática". Os outros tópicos das conferências eram: "Introdução; teorias de dramaturgia; caracterização psicológica; diálogo; e análise de peças ${ }^{55 " .}$.

De modo semelhante ao que já fazia no Laboratório de Atuação, Boal se servia de alguns conceitos da dialética hegeliana - aplicados ao debate sobre o drama - que o acompanhariam por muito tempo, em leituras cada vez mais pessoais, a ponto de se converterem em princípios fundamentais de sua própria visão sobre o teatro.

Seu programa pedagógico nesses cursos de 1956 e 1957, no que se refere aos temas descritos, acompanhavam o programa da Universidade de Columbia. A sua grade de estudos lá, de acordo com uma descrição feita depois, era composta por: "Shakespeare; drama moderno; direção; teatro grego; playwriting, com John Gassner ${ }^{\prime 56}$. A menção isolada ao nome do professor modelar chama a atenção: John Gassner era um famoso teórico da época, mas outros de seus professores tais como, Milton Smith, Maurice Valency, Norris Houghton e Theodore Apstein não eram menos célebres. Essa profunda influência de Gassner se mostra no uso que Boal fez das técnicas de playwriting transmitidas por ele. Em paralelo, Gassner também pensava a

\footnotetext{
${ }^{55}$ Lima, Mariângela Alves de. História das Idéias. In Dionysos. Rio de Janeiro: Ministério da Educação e CulturaFunarte, 1978, p. 42

${ }^{56}$ Boal, Augusto. Hamlet e o Filho do Padeiro. Rio de Janeiro: Editora Record, 2000, p. 123.
} 
dramaturgia na sua interação com uma nova cena. Não por acaso, foi ele quem levou Boal a ser ouvinte nas aulas do Actor's Studio.

Essa grande influência marcará em Boal a busca por um teatro desenvolvido a partir das técnicas dialéticas do Drama, em sintonia com a linguagem da nova cena realista norte-americana.

Gassner acreditava na superioridade do realismo como linguagem teatral, como deixa claro na seguinte afirmação: "Continuamos a considerar o teatro do século $X X$

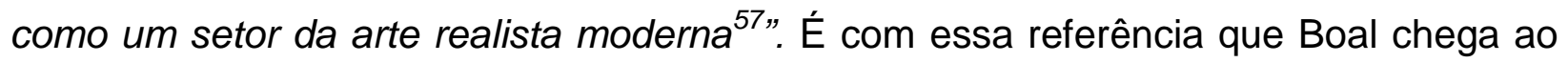
Arena. Sua exigência de sofisticação dramatúrgica contribuirá para aprofundar uma crise que se anunciava desde a fundação do Arena: a de repertório.

Que textos seriam capazes de manter viva uma pequena companhia teatral dependente de bilheteria, e portanto sujeita aos supostos interesses de entretenimento do público, sem afastá-la de uma procura técnica e temática mais radical?

O fato é que, com todo seu conhecimento de então, Boal não parecia encontrar um repertório capaz de conciliar perspectivas que pareciam mais desintegrar do que integrar o coletivo do Arena.

Enquanto o Curso de dramaturgia e o Laboratório de Interpretação prosseguiam gerando uma pesquisa inovadora (o que estimulava de modo inédito os interesses da parte mais jovem do grupo), a crise de repertório, agravada pelas dinâmicas empresariais da companhia, aprofundava o descontentamento de outros. Separavamse os propósitos da pesquisa dos atores e das peças efetivamente levadas à cena. A

${ }^{57}$ Gassner, John. Rumos do Teatro Moderno. Rio de Janeiro: Lidador , 1965, p. 30. 
escolha do repertório, a rigor, não era feita apenas por Boal, mas também por outros diretores convidados, em um sistema de rodízio ${ }^{58}$. E aos atores - sobretudo àqueles já interessados na reflexão sobre temática nacional - parecia enorme a dificuldade de valorizar um repertório que não fazia eco às formulações dos laboratórios. Boal comenta essa crise anos mais tarde, em seu livro de memórias:

\begin{abstract}
"Na alternância Renato montou Silveira Sampaio, Só o Faraó Tem Alma, Alfredo Mesquita dirigiu um espetáculo duplo, A Falecida Senhora Sua Mãe, de Feydeau, e Casal de Velhos de Mirbeau e eu, que não gostava de ecletismo insisti no filão realista, They Knew What They Wanted, com o espantoso título de A Mulher do Outro ${ }^{59}$, de Sidney Howard, que nos permitia continuar Stanislavski com peças estrangeiras. Fazendeiros norte-americanos, nada a ver com os brasileiros. A globalização cultural ainda não tinha operado em nós a prótese do desejo, ainda desejávamos falar de nós, ouvir nossa voz, ver nosso rosto". 60
\end{abstract}

Por trás do ecletismo de repertório, Boal tentava garantir ao menos a coerência da pesquisa de atuação ${ }^{61}$. Era a base comum que permanecia: realismo stanislavskiano.

\footnotetext{
${ }^{58}$ Boal comenta a conversa que teve com José Renato quando este o convidou para entrar no Arena; ao perguntar se José Renato tinha confiança nele, ouviu: "Não tenho nem deixo de ter, não te conheço. Mas preciso de um diretor para dividir comigo o repertório. Estou na televisão e não me sobra tempo". Boal, Augusto. Hamlet e o Filho do Padeiro. Rio de Janeiro: Editora Record, 2000, p. 139.

${ }^{59}$ A peça citada por Boal , A Mulher do Outro, foi encenada em janeiro de 1958.

${ }^{60}$ Boal, Augusto. Hamlet e o Filho do Padeiro. Rio de Janeiro: Editora Record, 2000, p.153

${ }^{61}$ Como podemos notar levavam a cabo a determinação da Lei № 1.565, de 3 de março de 1952, que exigia que a cada três peças encenadas uma fosse brasileira. A Lei promulgada por Getúlio Vargas era constituída pelos quatro artigos a seguir: "Art 10 Decorrido um ano após a publicação desta Lei, as companhias teatrais nacionais, de qualquer gênero, serão obrigadas, durante suas temporadas, a representar, no mínimo, em cada série de três peças, uma de autor brasileiro. Art $2 \circ$ Toda empresa teatral, ao solicitar licença para a realização de espetáculos de estréia de companhia nacional, apresentará relação do repertório programado para a temporada. Art 3o A empresa que não cumprir a exigência do art. 1ㅇ desta Lei terá a respectiva licença cassada. Art $4 \div$ A fiscalização do
} 
Estava claro, porém, que faltava atrelar as inovações interpretativas a peças que tratassem de questões nacionais e populares.

\section{0 auge da crise de repertório}

No ano de 1957, cinco peças de diferentes estilos e linguagens foram encenadas no Teatro de Arena. Boal inaugura nesse mesmo ano sua trajetória como dramaturgo e encena, ele próprio, seu primeiro texto: Marido Magro, Mulher Chata ${ }^{62}$. Era uma precária resposta inicial ao projeto de encenar um texto autoral capaz de tratar de temática nacional numa forma, a comédia, de tendência à aceitação popular.

Boal definiu sua peça como "uma comédia copacabanense, de poucos cenários e personagens jovens, ${ }^{\prime 63}$, o que sublinhava a tentativa de reproduzir a fala e os gestos de um local específico do país. Segundo a opinião do crítico Nicanor Miranda, que escreveu à época sobre a peça, foi justamente a incapacidade mimética que direcionou a dramaturgia ao fracasso:

“Augusto Boal estudou teatro nos Estados Unidos. A julgar por Marido Magro, Mulher Chata, uma coisa é certa: que aprendeu em dose satisfatória o que os

que determina esta Lei poderá ser exercida pela Censura do Teatro e Cinema do Departamento Federal de Segurança Pública, pelo Serviço Nacional de Teatro, pelas sociedades defensoras dos direitos dos autores e pelos respectivos delegados nos Estados e Territórios". In www.jurisway.org.br.

${ }^{62}$ Já havia sido montado um texto de Boal na universidade de Colúmbia, nos EUA: The Horse And The Saint, mas no Brasil esse era o primeiro trabalho. Boal, Augusto. Hamlet e o Filho do Padeiro. Rio de Janeiro: Editora Record, 2000, p. 132.

${ }^{63}$ Boal, Augusto. Programa da peça Marido Magro, Mulher Chata, p. 5 
norte-americanos chamam de "art of playwriting". A primeira confissão ${ }^{64}$ não condiz rigorosamente com o texto. A ação tanto pode passar-se em Copacabana, como em Roma ou Nova York. Os personagens, também, nada têm que os marque como tipos de Copacabana. Podem ser de qualquer outra metrópole ou cidade grande, nacional ou estrangeira"65.

Apesar de ter sido uma tentativa de um retrato à brasileira, a peça de fato está bem longe de qualque sentido crítico politizado. Ainda assim, de um ponto de vista cênico, incorporava o realismo laboratorial e um desejo de representação popular. Pode-se dizer que, em 1957, o estudo dos gestos brasileiros já era um projeto consciente do Arena, ainda limitado pela insuficiência do repertório disponível. A dificuldade de unir a pesquisa do gesto brasileiro (uma atuação "que fosse nossa", na expressão do grupo) aos textos escolhidos foi observada por José Renato em um depoimento dado anos mais tarde, em que analisa duas montagens de1957:

"A gente fazia laboratório, sim. Com uma das peças, por exemplo, que não funcionou muito e que causou muitas discussões entre nós - Juno e o Pavão...e Só o Faraó tem Alma, a gente chegou a fazer muitos laboratórios a respeito de como determinadas cenas deveriam ser realizadas. Repetíamos a mesma cena várias vezes de maneiras diferentes, procurando localizar onde estaria o tal jeito nosso, o tal gestual, a tal linguagem ${ }^{66 \prime \prime}$.

${ }^{64} \mathrm{O}$ trecho do programa da peça Marido Magro, Mulher Chata: "é um estudo psicológico da gente moça de Copacabana preocupada com o problema sexual", é chamado pelo crítico de "primeira confissão de Boal".

${ }^{65}$ Miranda, Nicanor. In http://www2.uol.com.br/teatroarena/arena.html

${ }^{66}$ Pécora, José Renato. In Ciclo de Palestras sobre o Teatro Brasileiro. Rio de Janeiro: MINC INACEN, 1984, p.23 
Era tácito, àquela altura, que os diretores deveriam buscar uma gestualidade nacional na interpretação, para o que era preciso um detalhamento novo. Fosse numa peça estrangeira como Juno e o Pavão, de Sean O'Casey, ou numa peça nacional, como Só o Faraó tem Alma, de Silveira Sampaio, a dificuldade era a mesma. E o grupo percebia um fosso que se abria entre seus processos de pesquisa e produtos cênicos. Ainda no comentário sobre esses dois textos de 1957, José Renato dá mostras de percepção sobre as causas do limite:

"Chegamos à conclusão, a exemplo de Brecht, de que esse tratamento já tem que existir intrinsecamente na estrutura do texto, para além da contribuição do ator ou do diretor. Então, quando você pega um texto, vamos dizer, de Plínio Marcos, você já encontra embutida nele aquela linguagem autêntica que só pode ser feita daquele jeito. Assim, no Juno e o Pavão, a gente tinha muito mais dificuldade de encontrar os tons adequados do que na peça de Silveira Sampaio, embora esta seja um gênero de comédia extremamente sofisticado. ${ }^{167}$

Ainda que a comédia do autor brasileiro pudesse ser "extremamente sofisticada", seu gênero parecia mais aberto a intereferências livres da cena do que a forma fechada do drama. Talvez seja essa a razão do relativo sucesso do espetáculo, que teve sua atuação elogiada pela crítica da época. ${ }^{68}$

\footnotetext{
${ }^{67}$ Pécora, José Renato. In Ciclo de Palestras sobre o Teatro Brasileiro. Rio de Janeiro: MINC, INACEN, 1984, p.23

68 "José Renato na direção procurou ressaltar as qualidades principais da obra, enfrentando com garbo e equilibrio o estilo próprio e particularíssimo do autor. Quanto à interpretação, pode-se dizer que é mais uma vitória desse excelente conjunto... Não se pode, sinceramente, ressaltar este ou aquele, pois o êxito da noite, no que diz respeito
} 
Dentro dessa perspectiva, mesmo que as peças de Sean O'Casey e de Sidney Howard soassem um tanto quanto deslocadas, já foram escolhidas segundo um viés social e político que permitia a Boal continuar com sua pesquisa sobre a linguagem realista, sem perturbar o caminho de integração entre teoria e prática que estava em curso.

Ampliava-se a necessidade de uma ligação dialética entre o trabalho de atuação realista e de criação de uma dramaturgia nova, ao mesmo tempo nacional, social e moderna. Sem essa interação diminuiriam as chances de um sentido social mais amplo do trabalho estético.

No dia-a-dia da companhia, contudo, continuavam vivendo a questão como dicotomia: de um lado a vontade de um teatro capaz de se politizar (o que pedia uma reflexão sobre o sentido do projeto nacional-popular que advinha das tendências dominantes no debate cultural do Partido Comunista $^{69}$ ), de outro lado, a realidade de um repertório cujos melhores textos eram peças da tradição dramática moderna norteamericana, com seus dramas sociais acentuadamente psicológicos.

Essa dualidade, que muitas vezes se encaminha para uma interação produtiva, vai marcar o novo Arena que surge após o movimento laboratorial de 1956 e 1957.

à interpretação, é resultado desse equilibrio de interpretação dos vários atores." Giovannini, Luiz. Só o Faraó tem Alma in http://www2.uol.com.br/teatroarena/arena.html.

${ }^{69}$ Maria Silvia Betti comenta a influência da ideologia do PC no Arena: "No Brasil, o marxismo encontra-se mais ligado às estruturas universitárias do que às partidárias, já que, nestas, privilegia-se a abordagem de documentos do PC soviético. Tais características merecem ser observadas pelo fato de o Arena apresentar tendências comuns ao PCB no que se refere à composição social de seus integrantes e de seu público, e de compartilhar dos pontos de vista postulados nos programas de atuação do Partido. Deve-se lembrar que no Arena fazem-se presentes tanto elementos de formação universitária quanto membros do partido (o próprio Vianinha) que confere a essas questões grande representatividade para entender-se a importância que tais temas (nacionalismo, reformismo e caráter frentista de atuação) adquirem nas formulações do grupo". Betti, Maria Silvia. Oduvaldo Vianna Filho. São Paulo: Edusp, 1997, p. 21 
Começa aí uma tensão teórica e formal: os conteúdos sociais e políticos com "cor local", a partir de uma orientação estética realista, são como que dimensionados por modelos da tradição técnica do playwriting dramático, que dava conta principalmente de assuntos do âmbito privado e familiar da vida burguesa ${ }^{70}$.

No mesmo ano de 1957, em meio a uma quase permanente dificuldade econômica em que vivia o Arena, José Renato decide fazer uma temporada no Nordeste, com as peças Ratos e Homens e Juno e o Pavão. O diretor antevia ali uma possibilidade de ir "atrás de receitas para saldar dívidas"71.

Já para Vianinha, Boal e Guanieri, era a chance de entrar em contato mais de perto com uma realidade brasileira que não conheciam e divulgar o trabalho de pesquisa e militância de parte dos integrantes do Arena.

A pesquisadora Maria Silvia Betti, estudiosa da obra de Vianinha, destaca a viagem como importante para os rumos do grupo: "A excursão que o Arena empreende, em 1957, pelo Nordeste, com as montagens de Ratos e Homens e Juno e o Pavão, é outro dado que antecipa a idéia de uma "cultura popular" enquanto objeto. Interessado em aproveitar o ensejo para informar-se acerca dos problemas econômicos e da cultura da região, Vianinha leva uma lista de nomes para contatos..."72 $^{72}$

Da viagem trouxeram uma receita menor do que almejava José Renato. Mas a troca cultural e a expansão do conhecimento sobre o país marcaram o grupo

\footnotetext{
${ }^{70}$ Sobre o assunto ver Costa, Iná Camargo: A Hora do Teatro Épico no Brasil. São Paulo: Graal, Paz e Terra, 1996 e Szondi, Peter. Teoria do Drama Moderno (1880-1950). São Paulo: Cosac \& Naify, 2003.

${ }^{71}$ Moraes, Dênis de. Vianinha, Cúmplice da Paixão. Rio de Janeiro: Editora Record, 2000, p. 69.

${ }^{72}$ Betti, Maria Silvia. Oduvaldo Vianna Filho. São Paulo: EDUSP, 1997, pp. 75, 76.
} 
definitivamente ${ }^{73}$, contribuindo para organizar um novo período de trabalho estéticopolítico.

\section{Black Tie como resultado da crise}

Em fins de 1957, o Teatro de Arena, portanto, estava longe de ser uma companhia convencional interessada num conceito vago chamado teatro moderno. Já existia ali um projeto, não totalmente formulado, mas visível na revolução operada nas relações de trabalho do grupo. A tomada de posição em favor de um trabalho essencialmente coletivo é descrita por Vianinha nos seguintes termos, tempos depois:

"O Teatro de Arena... teve que tomar uma atitude decisiva, que apareceu com a chegada de Augusto Boal: a mobilização de todo o Teatro de Arena para criar o espetáculo. Deixou de haver funções estanques de ator, diretor, iluminador etc. O Arena tornou-se uma equipe, não no sentido amistoso do termo (no sentido amistoso do termo, realmente, quero crer que quase todas as companhias são equipes), mas no sentido criador. Todos os atores do Arena tiveram acesso à orientação do teatro; orientação comercial, intelectual, publicitária. Boal mobilizou toda a imensa capacidade ociosa existente; Flávio Migliaccio que só fazia pontas e carregava material de contraregragem, praticamente inventou um novo ator no Brasil $^{74 "}$.

\footnotetext{
73 "A temporada em Salvador, a mais esperada da viagem, não rendeu financeiramente tanto quanto José Renato imaginara, mas, do ponto de vista artístico, foi compensadora". Moraes, Dênis de. Vianinha, Cúmplice da Paixão. Rio de Janeiro: Editora Record, 2000, p. 69.

${ }^{74}$ Vianinha. Do Arena ao CPC. In Peixoto, Fernando (Org). Vianinha. Teatro, Televisão, Política. São Paulo: Brasiliense. 1983, p. 92
} 
Será esse trabalho não especializado, por meio do qual os integrantes do Arena intercambiam todas as funções de uma montagem teatral que permitirá o desenvolvimento da idéia de uma autoria necessária e partilhada. Com essa postura autoral coletiva, todos da equipe expandem seu papel político dentro do grupo, pois a relativização da figura centralizadora do diretor geral ou do dono do teatro (Boal tinha o papel apenas de organizador da discussão), faz com que cada integrante passe a assumir sua responsabilidade sobre o destino do grupo e tenha que expor suas opiniões individuais.

É dentro dessa lógica que Gianfrancesco Guarnieri e os outros integrantes do Arena começam a escrever peças, levando adiante as orientações de dialética dramática do Curso de Dramaturgia e a procura de uma gestualidade brasileira do Laboratório de Atuação. E será a primeira incursão do ator pela dramaturgia que sintetizará as contradições anteriores, a ponto de abrir uma nova fase de trabalho no grupo e na história do teatro moderno em São Paulo. Em contraste com as peças anteriores do Arena, de fato Black Tie deve ser encarado como um marco. Entretanto, é também o resultado parcial de um processo anterior, intenso e latente. Para um artista como Boal, a peça nascia de uma necessidade construída:

"Se antes os nossos caipiras eram afrancesados pelos atores luxuosos, agora, os revolucionários irlandeses eram gente do Brás. A interpretação mais brasileira era dada aos atores mais Steinbeck e O'Casey. Continuava a dicotomia, agora invertida. Tornou-se necessária a criação de uma 
dramaturgia que criasse personagens brasileiros para os nossos atores ${ }^{\prime \prime 75}$.

Em fins de 1957, os integrantes do Arena tinham chegado ao ponto em que a continuidade das pesquisas só faria sentido em face de textos apropriados. E que deveriam ser escritos dentro do círculo de influência do próprio grupo. Não bastava a essa dramaturgia ser nacional simplesmente, como Boal tentou com seu Marido Magro, Mulher Chata. Era preciso que tivesse pontos de contato mais efetivos com a pesquisa que realizavam. É esse o feito da peça de Guarnieri.

Evidentemente, parte do sucesso do trabalho decorre da dedicação pessoal do ator à tarefa, inspirado pelos debates do Curso e do grupo:

"Eu comecei a escrever para teatro após a chegada do Augusto Boal ao Arena. Eu estava muito entusiasmado com essa descoberta e esse estudo da dramaturgia brasileira. Nós só discutíamos isso no Arena, vivíamos para esse fim. Eu sentia que precisava fazer alguma coisa para colaborar com aquele processo, então decidi escrever. Escrevia à noite, de madrugada, quando chegava em casa $^{76 \prime \prime}$

Por outro lado, a tarefa de Guarnieri era também coletivizada, resultante de um processo partilhado, em que o texto era discutido com os outros integrantes durante

\footnotetext{
${ }^{75}$ Boal, Augusto. Teatro do Oprimido e Outras Poéticas Políticas. Rio de Janeiro: Editora Civilização Brasileira, 1980, pp. 178, 179.

${ }^{76}$ Guarnieri, Gianfrancesco. In Roveri, Sérgio. Gianfrancesco Guarnieri. Um Grito Solto no Ar. São Paulo: Imprensa Oficial, 2004, p. 76.
} 
sua produção, num ambiente favorável, segundo depoimento do diretor do espetáculo, José Renato:

"Fim de 57, início de 58, Guarnieri me mostrou uma peça chamada 0 Cruzeiro Lá do Alto. Li a peça, gostei, pedi para alterar umas coisinhas, Guarnieri também alterou, pedi para mudar também o título, que não me parecia muito bom. Então ele mudou para Eles Não Usam Black Tie ${ }^{77 \text { ” }}$

\section{O modelo Eles não usam black tie}

É freqüente na historiografia do Arena a imagem de que Black Tie surgiu para salvar o grupo de um fechamento iminente. De fato, a crise financeira era uma constante. E a decisão de levar ao palco a peça de Guarnieri, que vinha sendo trabalhada desde o ano anterior, era uma aposta que podia significar o fechamento das portas e confirmar a idéia de que uma pesquisa laboratorial não tem lugar no teatro profissional, como comenta Boal em suas memórias:

"Nosso curso de Dramaturgia dava seus primeiros frutos. Com o Laboratório buscávamos formas brasileiras de atuar, mas as peças eram estrangeiras. Crise! Ou vai ou racha. Ou nos afirmamos como somos ou fechamos! Decidimos montar Eles Não Usam Black Tie". ${ }^{78}$

\footnotetext{
${ }^{77}$ Pécora, José Renato. In Ciclo de Palestras sobre o Teatro Brasileiro. São Paulo: MINC INACEN, 1984, p.15.

${ }^{78}$ Boal. Augusto. Hamlet e o Filho do Padeiro. Rio de Janeiro: Editora Record, 2000, p. 158.
} 
A imagem da peça salvadora diante do fechamento incontornável tem seu fundo de verdade ${ }^{79}$. Entretanto, a pesquisadora Cláudia de Arruda Campos traz indícios de que os integrantes do grupo construíram essa imagem salvacionista depois do sucesso da peça, pois o Teatro de Arena chegou a ser reformado para abrigar a montagem. Ela lembra: "É, inclusive, nessa ocasião que o Arena foi acarpetado" sugere que no fim anunciado do Arena, já existia um recomeço programado. Tudo indica, segundo ela, que "em algum momento dos preparativos a equipe tenha começado a apostar no texto que escolhera para encerramento de carreira ${ }^{81 "}$.

Em 1958, diante de uma crise generalizada, de aspectos positivos e negativos, a verdade é que o Teatro de Arena já podia ser considerado um coletivo com produção própria, mas ainda incapaz de impor seus interesses estéticos e políticos às condições da sobrevivência material. Black Tie mudaria essa perspectiva, como fica claro na fala de José Renato:

\begin{abstract}
"Nas três primeiras semanas de Black Tie, a afluência irregular de público fez com que a gente começasse a pensar logo em outra peça; escolhi Chapetuba Futebol Clube, de Vianinha. Fizemos as primeiras leituras, mas o Black Tie estourou ${ }^{82 ” .}$
\end{abstract}

O projeto estético do qual a peça fazia parte demonstra sua força. Um novo futuro para o grupo se abre. Seja como for, "deixemos viver a lenda ou a face mais

\footnotetext{
79 "O que aconteceu é que o Arena entrou em crise. Muita gente teve que sair, inclusive Boal e Vianinha. Problema de dinheiro. Do grupo mais firme ficaram José Renato, Flávio Migliaccio, Milton Gonçalves e eu. O Zé Renato decidiu montar Eles não Usam Black Tie para fechar o teatro, seria o último espetáculo. Foi para terminar tudo". Guarnieri, Gianfrancesco. In Peixoto, Fernando. Entrevista com Gianfrancesco Guarnieri. In Encontros com a Civilização Brasileira. Rio de Janeiro: Editora Civilização Brasileira, 1978, p. 102

${ }^{80}$ Campos, Cláudia de Arruda. Zumbi, Tiradentes. São Paulo: Editora Perspectiva, 1988, p. 38.

${ }^{81}$ Campos, Cláudia de Arruda. Zumbi, Tiradentes. São Paulo: Editora Perspectiva, 1988, p. 38.

82 Pécora, José Renato. In Ciclo de Palestras sobre o Teatro Brasileiro. Rio de Janeiro: MINC INACEN, 1984, p. 15.
} 
bonita da verdade: o réquiem às avessas ${ }^{83}$," como o definiu Cláudia de Arruda Campos, sobre a imagem do fim anunciado. Mais do que uma salvação, Black Tie mostrou que o caminho de aplicação livre de uma dialética entre teoria e prática poderia ser modelar como nova dramaturgia e interessar aos novos públicos do teatro da cidade.

\section{Interpretação Dialética}

Como já se observou tantas vezes, o impacto de Eles Não Usam Black Tie deve muito a seu tema: a peça apresentava membros da classe operária como protagonistas. Sua ação se passa em um morro carioca e retrata o cotidiano da família de Romana e Otávio, e de seus filhos Tião e Chiquinho. O pai e Tião trabalham em uma fábrica e quando os funcionários decidem entrar em greve, o filho, prestes a casar com a noiva Maria, que está grávida, hesita entre aderir ou não à greve. Em torno desse conflito central, todos os demais se estabelecem.

Para representar esse grupo de novos personagens - moradores dos morros cariocas, trabalhadores, sindicalistas, entre outros - era preciso uma encenação capaz de gerar imagens vivas. Mas a união entre a pesquisa laboratorial e a encenação era facilitada por estar, de certo modo, prevista no próprio texto. O caráter inovador da montagem impressionou seus contemporâneos a ponto de redefinir paradigmas de

\footnotetext{
${ }^{83}$ Campos, Cláudia de Arruda. Zumbi, Tiradentes. São Paulo: Perspectiva, 1988, p. 38.
} 
atuação e de escrita dramatúrgica, como lembra o ator Nelson Xavier, que nessa época ainda não fazia parte do grupo:

\begin{abstract}
“"Me lembro perfeitamente da primeira vez que vi Eles não Usam Black Tie. Principalmente da atuação do Flavio (Migliaccio) e da Lélia (Abramo). Era uma coisa fantástica, uma interpretação... ele não dava importância para as palavras, ele as cuspia, sem pompa, uma fala natural que me deixou completamente fascinado. Ainda mais eu, que vinha daquela empostação toda que havia aprendido na EAD, eu nem sabia que podia se representar daquele jeito aquele tipo de personagem, foi uma revelação ${ }^{84 \prime \prime}$
\end{abstract}

A observação confirma o sentimento público de que surgia uma nova encenação brasileira, decorrente de uma pesquisa laboratorial de cerca de dois anos: não se sabia que "era possível interpretar daquele jeito". E a novidade temática do texto, na forma de uma cena radicalmente inédita, expunha seu sentido político.

\title{
Limites da forma dramática
}

O fator politizante mais evidente da peça não estava só na tematização da luta de classes, na medida em que, anteriormente, outras peças já haviam tocado na

\footnotetext{
${ }^{84}$ Entrevista concedida à presente autora na casa do ator, no Rio de Janeiro, em 25/10/2011.
} 
questão ${ }^{85}$. A novidade estava no fato de a luta de classes estruturar (do ponto de vista dos explorados) os conflitos individuais, como mostra a pesquisadora Iná Camargo

Costa:

"Coerente com o assunto, Guarnieri delimitou a ação da peça tomando a greve como eixo. Dividiu-a em três atos, dos quais o primeiro cobre o período de constatação de sua necessidade até a assembléia que a aprova; o segundo dá conta dos preparativos e delineia as atuações dos trabalhadores a favor $e$ contra; e o terceiro cobre o início da greve bem sucedida e suas conseqüências na vida dos participantes diretos e indiretos ${ }^{86 \prime}$.

Assim, o protagonista Tião tem à sua frente uma questão que é basicamente política: aderir ou não a uma greve. Entretanto, seu conflito ganha contornos mais dramáticos e subjetivos por conta de que a pressão sobre a decisão provém de seu pai, Otávio, um "veterano militante comunista" 87 ", que obviamente é a favor da greve. Não apenas ele, mas toda a comunidade do morro também se engaja na contenda, ficando ao lado dos trabalhadores e exigindo que Tião faça o mesmo. Dessa maneira, as personagens populares da peça transitam por um universo marcadamente político, 0 que foi um dos propósitos de seu autor, como afirma Guarnieri:

\footnotetext{
${ }^{85}$ Iná Camargo Costa comenta o assunto: "Para aquilatar melhor o tamanho do passo dado por Guarnieri bastam duas referências. A luta de classes tem sido tematizada no teatro brasileiro desde, pelo menos, os inacreditáveis melodramas de Joracy Camargo dos anos 30 - Deus Ihes Pague e outros menos lembrados como Maria Cachucha ou Marabá- até as peças do dramaturgo oficial do TBC, Abílio Pereira de Almeida, de Santa Marta Fabril S. A. Mas como convinha, digamos que o tema no máximo aparecia subordinado aos interesses e comportamentos da classe dominante." Costa, Iná Camargo. A Hora do Teatro Épico no Brasil. São Paulo: Graal, Editora Paz e Terra, 1996, pp. $37,38$.

${ }^{86}$ Costa, Iná Camargo. A Hora do Teatro Épico no Brasil. São Paulo: Graal, Editora Paz e Terra, 1996, p. 24.

${ }^{87}$ Costa, Iná Camargo. A Hora do Teatro Épico no Brasil. São Paulo: Graal, Editora Paz e Terra 1996, p. 24
} 
"Mas o Black Tie, a primeira peça que eu escrevi, assim meio sem querer, nasceu também de uma imensa necessidade... Eu era um estudante que fazia política estudantil. Vivia prá isso, realmente de corpo e alma. Talvez eu tivesse até intenções políticas. E peguei o teatro como uma forma de discutir isso. Mais política que qualquer outra coisa. O Black Tie tinha uma colocação política $^{88 \prime \prime}$.

Era claro para o autor que seu tema era de ordem coletiva e sua intenção crítica era rejeitar as hesitações pequeno burguesas de Tião. Mas seu aprendizado recente sobre as leis do drama lhe dizia que uma peça é feita de conflitos entre pessoas, indivíduos, que de um modo ou de outro internalizam ou se relacionam com a pressão mais geral do problema social.

Surgia assim uma contradição entre um projeto temático tendencialmente épico (a greve) e uma forma da tradição literária que se especializou em tratar de problemas inter-individuais no âmbito da família, a dramática. Como afirma o teórico Peter Szondi, o drama pressupõe que as personagens sejam mostradas através de características que são de ordem estritamente subjetivas:

"O drama se configura como forma quando a temática da peça se dá na esfera das relações intersubjetivas. É uma forma absoluta na medida em que é desligada de tudo que Ihe é externo, e é primária por representar apenas

\footnotetext{
${ }^{88}$ Peixoto, Fernando. Entrevista com Gianfrancesco Guarnieri. In Encontros com a Civilização Brasileira. Rio de Janeiro: Civilização Brasileira, 1978, pp. 102, 103
} 
a si mesma. Por isso, o drama acontece sempre no presente, com uma mesma unidade de tempo e de lugar. Sua expressão se dá através de diálogos ${ }^{89}{ }^{\prime \prime}$

A contradição da peça entre projeto formal e temático, com suas modificações e resoluções possíveis, marcará a história posterior do Arena e do Seminário de Dramaturgia.

Em Black Tie, Guarnieri conseguiu figurar questões nacionais, com temas que Ihe eram absolutamente contemporâneos como o sindicalismo ${ }^{90}$. Por outro lado, a forma dramática impunha limitações ao texto, como comenta a pesquisadora Iná Camargo Costa:

“...greve não é um assunto de ordem dramática, pois dificilmente os recursos oferecidos pelo diálogo dramático - o instrumento por excelência do drama - alcançam a sua amplitude. Recorrendo ao repertório da lógica formal, poderíamos dizer que a extensão (o tamanho) desse assunto é maior que o veículo (o diálogo dramático) ${ }^{91 "}$.

Como fica claro na análise de Iná Camargo Costa, o limite da forma dramática acaba por transformar o assunto épico - com todas as suas possibilidades de ativação

\footnotetext{
${ }^{89}$ Szondi, Peter. Teoria do Drama Moderno (1880-1950). São Paulo: Cosac \& Naif, 2003, pp. 105, 106

${ }^{90}$ Iná Camargo Costa comenta a questão: "A greve de Guarnieri registra, com mais verdade do que seria de supor, o vigoroso ascenso das lutas dos trabalhadores ao longo dos anos 50 - basicamente caracterizados pela ampliação de suas organizações sindicais, formação de federações e confederações". A Hora do Teatro Épico no Brasil. São Paulo: Graal, 1996, p. 38.

${ }^{91}$ Costa, Iná Camargo. A Hora do Teatro Épico no Brasil. São Paulo: Graal, 1996, p. 24.
} 
social - em um assunto de ordem pessoal: a personagem deve ou não tomar uma decisão segundo motivos que, ao fim das contas, são próprios, pois a peça não representa bem a dimensão extra-individual.

Outro elemento que relativa essa relação é o formato de arena do palco, que já trazia em si a exigência de uma própria teatralidade ao mesmo tempo íntima e epicizante, o que surgia como testemunho de algo diferente. Black Tie continha, assim, um conjunto de movimentos díspares, mas produtivos. Suas contradições internas eram resolvidas produtivamente numa relação cênica viva e nova entre palco e platéia. Era como se o público reconhecesse materializado ali um processo, um trabalho, mais do que uma obra pronta. E o processo exposto dizia respeito ao espectador do ponto de vista histórico: inacabado mas voltado para o futuro.

\section{Ética de teatro de grupo}

Por conta da repercussão da montagem de Black Tie, os integrantes do Arena recebem convites para diferentes trabalhos em outras companhias teatrais. Esse processo, que já estava em curso desde Ratos e Homens, de Steinbeck ${ }^{92}$, se amplia por algum tempo.

\footnotetext{
$92 \mathrm{Na}$ época da montagem de Black Tie, Boal continuava à frente do Curso e do Laboratório mas fazia trabalhos em diferentes companhias: "Como o dinheiro era escasso, não dava para todos. Recebi um convite para dirigir Society em Baby Doll, de Henrique Pongetti, no Teatro Moderno, do marido de Dercy, Danilo Bastos. Esse convite me fez sofrer. Meu coração apertou: o lógico era que eu fosse dirigir essa comédia e José Renato, dono e diretor permanente do teatro, abandonasse a televisão e dirigisse o Guarnieri... e assim foi resolvido. Constrangido tive
} 
Guarnieri ganhou visibilidade com Black Tie e saiu do Arena para realizar Gimba, peça de sua autoria, com a companhia de Maria Della Costa. Algum tempo depois teve a peça $A$ Semente, que desenvolve alguns temas de Black Tie, montada no TBC. Já José Renato, à essa época, realizava trabalhos na televisão e recebeu convite do Teatro Nacional Popular (TNP), de Jean Villar, na França, onde ficou até o final de 1959. Mesmo com toda essa movimentação gerada pela repercussão de seu trabalho, no ano de 1958, o grupo decide manter alguns caminhos de trabalho comum de modo a não ceder à pressão externa que poderia transformá-los em mão de obra qualificada para o "mercado" teatral, como lembra Guarnieri:

"Em termos de Arena, (Black Tie) teve também um resultado de grande importância: trouxe o pessoal de volta. Deu segurança ao grupo, deu para reorganizar. O sucesso despertou entusiasmo, animou outros a escreverem.". ${ }^{93}$

O trabalho coletivo de escrita será o principal meio de agregação do projeto, agora assumidamente nacional-popular do Teatro de Arena. Black Tie, tratado a partir de então como um símbolo ${ }^{94}$, confirma que a busca pelo texto nacional politizado,

que abandonar o Black Tie depois de já ter participado da escolha do elenco... Não desejo essa angústia a nenhum diretor: dirigir peça em um teatro, pensamento e afeto em outro." Boal, Augusto. Hamlet e o Filho do Padeiro. Rio de Janeiro: Editora Record, 2000, p. 158

93 Peixoto, Fernando. Entrevista com Gianfrancesco Guarnieri.In Encontros com a Civilização Brasileira. Rio de Janeiro: Editora Civilização Brasileira, 1978, p. 103

${ }_{94}$ "A aura que envolve o sucesso de Black Tie deixa a impressão de que o autor nacional teria surgido, em 1958, do limbo da absoluta inexistência. No entanto, apenas para nos atermos à fase de maior organicidade do movimento teatral, que se inicia em 1948 com a criação do TBC e da Escola de Arte Dramática, veremos que o autor nacional aparecia com relativa freqüência em nossos palcos. Entre os nomes mais relevantes, podemos citar Nelson Rodrigues como o principal autor do período; Abílio Pereira de Almeida tem diversas peças montadas, principalmente pelo TBC, desde 1948. Entre Rio e São Paulo, destacam-se ainda Pedro Bloch, Silveira Sampaio, 
voltada para uma interpretação brasileira, precisava de um laboratório próprio, menos técnico e mais criativo do que um simples curso. São essas as coordenadas fundamentais que o Seminário de Dramaturgia extrai da experiência de uma peça que confirma a aposta da linha mais combativa da pesquisa do grupo.

\section{Temática nacional-popular}

Com todas as contradições ideológicas que o conceito envolve, o pensamento nacional-popular significava no Arena daquele momento um impulso para uma prática conectada com as forças mais progressistas da época, nos termos da pesquisadora Maria Silvia Betti:

"Nesse período, a indústria de bens culturais de massa era incipiente, $e$ a idéia de um projeto de cultura nacional-popular não havia, ainda, sido cooptada pelos meios de comunicação, constituindo-se, portanto, em perspectiva de abertura para uma nova forma de atuação no campo cultural. Diante desse contexto, povo e nação, entendidos como elementos conceituais positivos e inovadores, trazem em si a perspectiva da renovação da práxis teatral e da integridade entre pensamento e atuação. Fortalece-se, assim, a referida visão crítica da história do teatro no Brasil, enquanto se desenvolve uma enriquecedora forma de atuação política e cultural ${ }^{95 ”}$.

Henrique Pongetti, Guilherme de Figueiredo, Millôr Fernandes". Campos, Cláudia de Arruda. Zumbi, Tiradentes. São Paulo: Editora Perspectiva, 1988, p. 41

${ }^{95}$ Betti, Maria Silvia. Oduvaldo Vianna Filho. São Paulo: Edusp, 1997, p. 16. 
Será essa a direção que o Arena toma a partir da encenação de Black Tie: a pesquisa laboratorial não pode mais ser dissociada das peças em cartaz. Assumem, pela primeira vez, um projeto estético totalizante, que une todas as áreas das realizações do grupo. Com esse direcionamento, a dramaturgia surge como o lugar de organização mais geral dos trabalhos. E, para isso decidem estudar a história da dramaturgia brasileira que os precedeu, o que não ocorrera até então, como comenta Guarnieri em uma entrevista dada anos depois:

"Está escrito nos estatutos (do TPE): valorização da dramaturgia nacional. Mas e daí? Ela estava onde? Era uma coisa muito vaga. Ao mesmo tempo tínhamos posições ideológicas e políticas, mas não aceitando o que se escrevia na época, não havia peças. Abílio no TBC, por exemplo, não era a nossa. Ligávamos o Abílio à burguesia. A gente achava que precisava do texto nacional, mas não sabia onde achar... Nem o Vianinha conhecia as peças do pai dele... Foi depois, que a gente começou a ler, a examinar.. ${ }^{96 \prime}$

Torna-se ainda mais forte a busca da "linguagem teatral genuinamente brasileira", tanto na fala quanto na atuação, como a realizada por algumas companhias de teatro popular ${ }^{97}$. Torna-se imprescindível o engajamento.

\footnotetext{
${ }^{96}$ Peixoto, Fernando Guarnieri. Entrevista com Gianfrancesco Guarnieri.In Encontros com a Civilização Brasileira. Rio de Janeiro: Civilização Brasileira, 1978, p. 102

${ }^{97}$ Boal comenta seu fascínio ao dirigir Dercy Gonçalves, atriz ícone do teatro popular da época: "No caso de Dercy... eu quis mesmo trabalhar com ela, expressa vontade. Como teria gostado de trabalhar com o palhaço Piolim que conheci na juventude, ou qualquer daqueles atores de circo e revistas musicais, que tinham estilo próprio e grande domínio do público. Queria conhecê-los. Vê-los no ato da criação. Bem diferente dos ensaios no Arena em que debatíamos o significado profundo de cada gesto, a importância metafísica de cada olhar, fazíamos a exegese filosófica de cada pausa! Com Dercy o riso era linguagem... convidei atores do Arena para observarem os ensaios, mergulhados no escuro do fundo da sala. Eles se maravilharam". Boal. Augusto. Hamlet e o Filho do Padeiro. Rio de Janeiro: Editora Record, 2000, pp. 161, 162.
} 
A fundação do Seminário de Dramaturgia, que ocorre no mesmo ano de estréia de Black Tie, 1958, corresponde a essa necessidade de formação que não é apenas do grupo, mas de um teatro que se pensa dentro do conjunto do teatro da cidade e do país. O dramaturgo precisa ser um pesquisador, estudioso de uma arte engajada social e politicamente, e para isso faz-se necessário repensar o conjunto de sua história. 


\section{Capítulo 3}

\section{Dialética do Seminário de Dramaturgia}

O Seminário de Dramaturgia do Teatro de Arena foi organizado como um laboratório de escrita, capaz de aprofundar a politização crescente do grupo e a necessidade de interação dialética entre a dramaturgia e a interpretação. Destinava-se apenas aos integrantes do Arena e escritores convidados.

O Seminário não seguia o programa das aulas que Boal havia trazido da Universidade de Columbia, utilizado nos cursos anteriores. No que se refere a seu formato, era constituído por encontros semanais de debates sobre escrita dramatúrgica com vistas a estimular a produção, como descreve Boal em suas memórias:

"Em 1958, depois da estréia de Eles não usam Black Tie, resolvemos fundar o Seminário de Dramaturgia para aprofundar nosso estudo, agora em pequeno grupo. O Seminário seria para convidados e o Curso para todos. Reunimos doze futuros autores profissionais, alguns já tendo escrito, outros nem uma linha. Reuniões aos sábados de manhã para analisarmos peças com, no mínimo dois relatores - um dos quais sempre eu, já que me supunham conhecedor de carpintaria teatral: para isso tinha estudado na Columbia University. ${ }^{98}$

\footnotetext{
${ }^{98}$ Boal, Augusto. Hamlet e o Filho do Padeiro. Rio de Janeiro: Editora Record, 2000, p. 149. Boal pensava em continuar o curso aberto ao público no Arena, mas acabou mudando de idéia, como relata a seguir: "Na verdade, em 57, o Seminário organizava cursos e reuniões informais, mas só adquiriu a forma... depois de Black Tie, em 58. Em 1959, Alfredo Mesquita me convidou para inaugurar dramaturgia na Escola de Arte Dramática, o que tornou desnecessário os cursos do Arena: quem quisesse que fosse para a EAD". Boal, Augusto. Hamlet e o Filho do Padeiro. Rio de Janeiro: Editora Record, 2000, p. 150.
} 
A rigor, o modelo metodológico do Seminário não vinha de Columbia, mas do grupo livre extra-acadêmico que Boal conheceu nos Estados Unidos, em 1954: o Writer-s group. Essa experiência anterior é descrita pelo próprio Boal em termos semelhantes ao comentário sobre o Seminário: "Nos reuníamos e líamos nossas peças. Um relator tinha a obrigação de ler e fazer relatório escrito, antes dos debates. Continuávamos juntos, duas, três horas, conversando". 99

Será esse modelo de uma produção livre que Boal adaptará ao Arena, duplicando a função da relatoria. $O$ aumento do número de relatores estimulava o debate e a polêmica sobre uma produção dramatúrgica em que o sentido formal e o ideológico não podiam ser mais dissociados. Assim, a estrutura de cada encontro do Seminário, tal como idealizada por Boal, obedecia à seguinte ordem programática:

\section{"I Prática:}

a- técnicas de dramaturgia;

b- análise e debates de peças.

II Teoria:

a- problemas estéticos de teatro;

b- características e tendências do moderno teatro brasileiro;

c- estudo da realidade artística e social brasileira;

$d$ - entrevistas, debates e conferências com personalidades do teatro brasileiro.

III Burocrática:

a- seleção e encaminhamento de peças escritas no Seminário;

b- divulgação de teses e resumo dos debates" ${ }^{\prime 100}$.

\footnotetext{
99 Boal, Augusto. Hamlet e o Filho do Padeiro. Rio de Janeiro: Editora Record, 2000, p. 127

100 Guimarães, Carmelinda. Seminário de Dramaturgia: Uma Avaliação 17 anos Depois. In Revista Dionysos, número 24. Rio de Janeiro: Ministério da Educação e Cultura- Funarte, 1978 p. 67
} 
Em torno dos integrantes do Seminário parecia haver um consenso de que para se discutir teatro era agora necessário se discutir também a realidade nacional. Essa tomada de posição vai além dos temas. Influencia diretamente a feitura das peças que serão discutidas. Radicaliza-se o projeto de um teatro engajado socialmente, de sentido nacional-popular, que traz para dentro da sala de ensaio a discussão política e a reflexão sobre o momento social.

Em paralelo ao Seminário de Dramaturgia, os artistas do Arena fazem viagens para conhecer de perto a realidade nacional, escrevem textos teóricos sobre essas experiências, e reposicionam o espectro de atuação possível de um grupo teatral. Essa nova forma de organização artística e política acabará ensejando a criação do CPC em 1960 e deixará um legado muito além dos palcos.

Fundado para ser um espaço de discussão dramatúrgica, a ênfase dos debates, desde o início, estava no conteúdo das peças analisadas e na visão de mundo que elas encerravam. Essa necessidade de problematizar assuntos amplos, que envolviam conjuntura, acabará por aumentar a contradição entre o projeto ideológico e os modelos formais, ainda predominantemente de ordem dramática.

Quando percebem que seus interesses críticos encaminhavam o projeto para uma reflexão sobre uma teatralidade que transborda os limites do drama, os integrantes do Seminário se vêem obrigados a refletir sobre seus caminhos formais num sentido novo. Enquanto essa contradição não estava clara, a equipe constatava que a novidade principal do trabalho do grupo era da ordem do conteúdo, como bem aponta Vianinha numa reflexão sobre o período: 
"Enquanto as outras companhias, sem muito para dizer de autêntico, comercializavam a sua forma, o Arena comercializava seus conteúdos, usando no público sua área mais urgente de indagações pelo mundo. Os problemas que menos distância possuíam da realidade social formam abordados. As mediações longínquas foram abolidas." 101

\title{
Os modelos teóricos dramáticos
}

\begin{abstract}
Desde os primeiros anos de estabelecimento da pesquisa de interpretação e dramaturgia no Arena, seus integrantes procuravam estudar o desenvolvimento histórico da dramaturgia ocidental. Nessa perspectiva leram e discutiram a Poética de Aristóteles, a Estética de Hegel, além de vários outros teóricos selecionados por Boal, como Ferdinand Brunetiere, Henri Bergson e primordialmente John Howard Lawson. Um dos alunos de Boal na Escola de Arte Dramática, Lauro César Muniz, comentaria anos depois:
\end{abstract}

"Conheci o sistema colocado pelo Boal, apoiado na dialética hegeliana, que ele aperfeiçoou, a partir de John Howard Lawson um teórico americano, de forte presença das décadas de 1930 e 1940. Tempos depois acabei por ler o livro básico do Lawson e entendi que o Boal havia dado um passo à frente, aperfeiçoando a teoria do roteirista americano. Ao contrário de outros métodos, que propõem fórmulas rígidas, fechadas, como um receituário, a visão de Boal cria todo um universo, uma forma rica para encarar a

\footnotetext{
101 Vianinha. Do Arena ao CPC. In Peixoto, Fernando (Org). Vianinha. Teatro, Televisão, Política. São Paulo:
} Brasiliense. 1983, p. 91 
dramaturgia, com apoio da dialética hegeliana: um processo de análise da natureza, riquíssimo, forte, abrangente, adaptado para a dramaturgia" ${ }^{102}$.

Como fica claro na citação, a estruturação do programa de estudos veio em sintonia com a prática, atendendo às possibilidades de autores "jovens de pouca idade sem experiência de vida", como os definiu Boal. O mais importante era que todos de fato "estudaram, discutiram, escreveram ${ }^{103 " . ~ E ~ s u a ~ b a s e, ~ d e s d e ~ o ~ m o m e n t o ~ e m ~ q u e ~ o ~}$ Laboratório de Atuação começou a pautar a mudança metodológica do grupo, foi formada a partir de uma leitura livre da dialética hegeliana.

A Dialética, esse método das contradições, tornava-se a grande ferramenta de trabalho dos jovens integrantes, tanto para a escrita como para a atuação:

"... e aplicou-se as leis da dialética: o conflito de vontades opostas desenvolve-se quantitativa e qualitativamente, dentro de uma estrutura conflitual interdependente. Assim, Stanislavski foi posto dentro de um sistema ${ }^{104 . "}$

Para que Stanislavski pudesse ser assim hegelianizado, era também preciso pensar o drama do ponto de vista da relação com os atores. O Arena não estudava os

\footnotetext{
${ }^{102}$ Muniz, Lauro César. O Ouro Verdadeiro. In. http://www.ar.art.br. Apesar de Boal não ter deixado escritos que sistematizassem essas influências, alunos seus, como Renata Pallotinni e o citado Lauro César Muniz o fizeram, além de depoimentos como o de Nelson Xavier, que em entrevista à presente aurora garantiu que Boal exigia a leitura desses três teóricos. Sobre o assunto ver: Pallottini, Renata. O que é Dramaturgia. São Paulo: Editora Brasiliense, pp 42 a 85.

${ }^{103}$ Boal, Augusto. Teatro do Oprimido e Outras Poéticas Políticas. Rio de Janeiro: Civilização Brasileira, 1980, pp.149, 150.

${ }_{104}$ Boal, Augusto. Teatro do Oprimido e Outras Poéticas Políticas. Rio de Janeiro: Civilização Brasileira, 1980, pp.149, 150.
} 
dois teóricos de maneira estanque, mas fazia um uso livre das teorias, através de um fluxo constante entre elas. Algo dessa síntese pode ser encontrada no livro 200 Exercícios e jogos para o ator e o não-ator com vontade de dizer algo através do teatro de Boal, sobretudo no estudo sobre a Estrutura Dialética da Interpretação ${ }^{105}$, que entrecruza as perspectivas de Hegel e Stanislavksi na busca de parâmetros amplos para o trabalho do ator.

O que estava realmente em curso no Seminário de Dramaturgia, de um ponto de vista crítico, é difícil saber ao certo. Parte dessa perspectiva pode hoje ser reconstituída com base nas escassas entrevistas e escritos posteriores. Mesmo coordenando o estudo e tendo escrito mais de vinte livros, Boal não realizou na época uma sistematização teórica de sua inovadora pedagogia de dramaturgia, e muito menos das mudanças de rumo de seu aprendizado pessoal no exterior a partir da interação com o trabalho do Arena. Estudar o trabalho do Seminário será sempre um esforço sobre hipóteses.

Por outro lado, existem em muitos dos textos de Boal, ainda que de modo esparso, comentários diretos sobre sua visão de dramaturgia. Encontráveis, sobretudo, nos escritos sobre atuação. Se comparados aos escritos de seus alunos que desenvolveram reflexões a partir do aprendizado com Boal, como os dramaturgos Renata Palottini e Lauro César Muniz, pode-se constituir uma possível imagem do que estava em jogo no aprendizado dialético do Seminário de Dramaturgia.

\footnotetext{
${ }^{105}$ Boal, Augusto. 200 Exercícios e Jogos para o Ator e o Não-Ator com Vontade de Dizer Algo Através do Teatro. Rio de Janeiro: Civilização Brasileira, 1982. pp. 48 a 57.
} 
Num depoimento sobre seu pensamento sobre dramaturgia, Boal apresenta uma síntese da teoria dramática hegeliana:

"... na poesia dramática coexistem a objetividade e a subjetividade, mas é importante notar que, para Hegel, esta precede aquela: a alma é o sujeito que determina toda ação exterior e interior. Como em Aristóteles, eram igualmente as paixões convertidas em atos as que moviam a ação. Nestes dois filósofos, o drama mostra a colisão exterior de forças originadas no interior, isto é, o conflito objetivo de forças subjetivas. ${ }^{1106}$

Boal tem clareza sobre a ênfase subjetiva da obra hegeliana. Sua análise destaca a estrutura montada pelo filósofo alemão para atingir o fulcro da criação dramática. Hegel sustenta o drama em dois aspectos fundamentais: a liberdade do sujeito que age e a maneira como esse sujeito expressa no mundo sua vontade livre. Ao manifestar-se como sujeito, ele entra em choque com a vontade livre do outro, e daí nasce o conflito, o cerne da ação, geradora do movimento que dá vida à obra dramática. Essa clássica dialética das vontades será um dos alicerces sobre o qual Boal construirá seu debate próprio sobre teoria do drama.

Anos depois, no seu livro mais conhecido, que sintetiza reflexões ligadas à fase do Arena, Boal compara os sistemas dramáticos de Aristóteles e Hegel. Em O Teatro do Oprimido ele mostra como, para Aristóteles, imitar quer dizer "recriar o movimento interno das coisas que se dirigem à perfeição. E a natureza é esse movimento ${ }^{107 " . ~}$

\footnotetext{
${ }^{106}$ Boal, Augusto. Teatro do Oprimido e Outras Poéticas Políticas. Rio de Janeiro: Civilização Brasileira, 1980, p. 97

${ }^{107}$ Boal, Augusto. Teatro do Oprimido e Outras Poéticas Políticas. Rio de Janeiro: Civilização Brasileira, 1980, p. 15
} 
Nessa leitura interessada no movimento, a arte e a ciência servem para recriar " 0 princípio criador das coisas criadas, corrigir a natureza naquilo que ela haja fracassado ${ }^{108 "}$. Segundo Boal, a visão de Aristóteles se encaminha, assim, para uma perspectiva controladora, na medida em que busca uma ordem maior do que a própria natureza. O aspecto fundamental do sistema trágico aristotélico estaria, portanto, em sua função repressiva:

"Este Sistema funciona para diminuir, aplacar, satisfazer e eliminar tudo que possa romper o equilibrio social; tudo, inclusive os impulsos revolucionários, transformadores ${ }^{109 "}$.

No nascimento do seu projeto do Teatro do Oprimido, Boal critica a "coercitiva" concepção de Aristóteles porque diz que "teatro é transformação, movimento e não simples apresentação do que existe. É tornar-se, e não, ser ${ }^{110}$."

Amparado em Hegel, ele sugere que uma representação da vida atenta a uma visão dinâmica do real não pode abrir mão do conceito de ação livre e responsável (praticamente inexistente no mundo grego). Confirma, de modo indireto, seu interesse por uma dramática da liberdade, sem deixar de estar atento ao fato de que a dialética do drama depende antes das contradições internas das personagens do que das externas.

\footnotetext{
${ }^{108}$ Boal, Augusto. Teatro do Oprimido e Outras Poéticas Políticas. Rio de Janeiro: Civilização Brasileira, 1980, p. 16

${ }^{109}$ Boal, Augusto. Teatro do Oprimido e Outras Poéticas Políticas. Rio de Janeiro: Civilização Brasileira, 1980, pp. $62,63$.

${ }^{110}$ Boal, Augusto. Teatro do Oprimido e Outras Poéticas Políticas. Rio de Janeiro: Civilização Brasileira, 1980, p. 31.
} 
Para se contrapor ao que ele considera uma idéia estática e imutável de tragédia, proposta por Aristóteles, destaca o vir a ser, o devir, de tanta importância para toda dialética de base idealista, em sua conexão com a subjetividade. Reitera, assim, a ênfase que Hegel dava à questão da liberdade:

"Hegel dizia que o personagem é livre, ou seja, os movimentos internos de sua alma devem sempre poder ser exteriorizados, sem freios. Porém liberdade não é qualquer coisa, mas consciência da necessidade ética. Assim, ele não deve exercer sua liberdade sobre qualquer coisa, mas sobre os valores e as situações comuns a toda humanidade, como o amor, o patriotismo, etc. ${ }^{111 "}$

Desse modo, Boal extrai de Hegel o interesse por personagens capazes de uma luta consciente com um princípio ético, estando sua liberdade possível na complexa concretização de sua existência no mundo. Os valores abstratos, morais, surgem no Drama através de porta-vozes de carne e osso. Diferentemente do que ocorria nas alegorias do teatro medieval, as personagens modernas criam relativa independência em relação aos valores que encarnam. A bondade e a personagem que a representa serão uma só e mesma coisa, embora diferentes: uma é o valor abstrato e a outra a sua concreção humana, sempre diversa. O mesmo é o outro: entretanto, para que haja drama, esse processo deve ser contemplado em suas diversas fases de desenvolvimento de um conflito que é, a um tempo, interno e externo.

\section{Subjetivação e objetivação}

\footnotetext{
${ }^{111}$ Boal, Augusto. Teatro do Oprimido e Outras Poéticas Políticas. Rio de Janeiro: Civilização Brasileira, 1980, pp. 82,83
} 
É importante ressaltar que as teorizações dialéticas de Boal, presentes em seus livros O Teatro do Oprimido e 200 Exercícios e jogos para o ator e o não-ator com vontade de dizer algo através do teatro, vieram a público na década de 70 , dez anos após o final do Seminário de Dramaturgia.

Se por um lado sabemos que seu estudo de Hegel, Aristóteles e Stanislavski corresponde ao período de pesquisas do Teatro de Arena, como escreve o próprio autor nos prefácios dos livros ${ }^{112}$, por outro, há uma síntese desse pensamento feita posteriormente, e portanto, inspirada em questões da época seguinte. É difícil, portanto, precisar o momento em que Boal começa a criticar os limites idealistas da visão dialética de Hegel sobre o drama que tanto inspiram sua fase inicial. Tudo indica, entretanto, que a desconfiança sobre as personagens dramáticas - essas criaturas plenamente conscientes e responsáveis em relação a seus conflitos morais - tenha se iniciado já no Seminário de Dramaturgia, como decorrência dos debates temáticos politizados que conduziam a uma reflexão sobre a medida de realismo imposta pela atualidade.

Em O Teatro do Oprimido, Boal já estava interessado em personagens sujeitas a condicionamentos e mecanizações, o que se faz claro pela citação abaixo:

\footnotetext{
${ }^{112}$ Diz Boal no prefácio de 200 Exercícios e Jogos para o Ator e o Não-Ator com Vontade de Dizer Algo Através do Teatro: "O propósito desse livro é sistematizar todos os exercícios utilizados pelo Teatro de Arena de São Paulo (Brasil) entre 1956 e 1971, período durante o qual fui seu diretor artístico". Boal, Augusto. Rio de Janeiro: Civilização Brasileira, 1982, p. 10. E Boal escreve na Explicação do livro Teatro do Oprimido: "Esse livro reúne ensaios escritos com diferentes propósitos, desde 1962 em São Paulo, até fins de 1973, em Buenos Aires". O ensaio que utilizamos no presente capítulo é: O Sistema Trágico Coercitivo de Aristóteles, de 1973. Boal, Augusto. Teatro do Oprimido e Outras Poéticas Políticas. Rio de Janeiro: Civilização Brasileira, 1980, p. 1.
} 
"O realismo (louvado por Marx) representou a segunda redução. $O$ homem passou a ser o produto direto de seu meio ambiente. $O$ realismo e $o$ naturalismo visavam apenas levar ao palco uma fatia de vida, ou uma realidade fotográfica, sem que o dramaturgo tomasse partido sobre ela. Depois disso vieram os movimentos subjetivistas como o impressionismo $e \quad o$ expressionismo e o surrealismo, que mostravam as emoções abstratas como medo, terror, angústia, etc. na cabeça do personagem que projetava exteriormente o seu mundo fantasmagórico. A variação do realismo se deu para dentro do personagem, em sua psicologia. Outra fuga do moderno teatro foi a busca de Deus como escape aos problemas materiais. (...) Assim, o teatro burguês ao invés de mostrar o homem em sua mecanização, o reduziu a novas abstrações, a saber: psicológicas, morais ou metafísicas ${ }^{113 "}$.

Embora aqui ele critique as peças do realismo e do naturalismo como igualmente "fotográficas" (posição de certo modo equivocada que demonstra em outras ocasiões), suas observações parecem dar prosseguimento a uma discussão que certamente rondou o Seminário, a da necessidade de uma "correção materialista" do estudo das estruturas fundamentais da técnica dramática. Para ele, o "teatro materialista-dialético" seria aquele em que:

“... Os personagens ainda têm função de objetos, mas objetos de funções sociais determinadas que, entrando em contradições desenvolvem um sistema de forças que determina o movimento da ação dramática"114.

\footnotetext{
${ }^{113}$ Boal, Augusto. Teatro do Oprimido e Outras Poéticas Políticas. Rio de Janeiro: Civilização Brasileira, 1980, pp. 85 a 88.

${ }^{114}$ Boal, Augusto. Teatro do Oprimido e Outras Poéticas Políticas. Rio de Janeiro: Civilização Brasileira, 1980,p. 89.
} 
Mesmo quando pende para a epicização da forma, porém, ele não se afasta completamente de Hegel, para quem um ponto importante do drama é que a ação não nasce de circunstâncias exteriores, mas sim da vontade e dos caracteres dos personagens. Por maior que seja a pressão social, a medida da ação livre deve estar representada, o que não é uma questão simples de realizar: "Para que se mostre esse sujeito livre no teatro, é necessário que este assim o seja. Portanto, ele não pode estar preso a dogmas, necessidades físicas, etc ${ }^{115 "}$.

Apesar dessa relativa oscilação, Boal diferencia com clareza conflitos de natureza moral dos conflitos interpessoais ligados à ordem social, ao mesmo tempo que reconhece, em meados dos anos 1970, que essa reflexão, central para o debate sobre teatro épico, pede uma análise mais aprofundada, pois se refere a um "teatro nascente, carece ainda de teorização."116

Nos tempos do Seminário, a possível crítica ao limite idealista do modelo hegeliano surgia antes por pressão dos temas nacionais, populares e politizados desejados pelo grupo do que por uma rigorosa teorização anti-dramática. A rigor, ainda predominava a dialética da vontade e contra-vontade nos termos subjetivos do drama, utilizada como ferramenta de organização da ação. No mencionado artigo Estrutura da Interpretação Dialética, Boal conceitua esses e vários outros termos:

"Vontade- O conceito fundamental para o ator não é o "ser" do personagem, mas o "querer". Não se deve perguntar quem é, mas o que quer. Mas a vontade escolhida pelo ator não pode ser arbitrária, antes será

\footnotetext{
${ }^{115}$ Boal, Augusto. Teatro do Oprimido e Outras Poéticas Políticas. Rio de Janeiro: Civilização Brasileira, 1980, p. 98 ${ }^{116}$ Boal, Augusto. Teatro do Oprimido e Outras Poéticas Políticas. Rio de Janeiro: Civilização Brasileira, 1980, p. 89
} 
necessariamente a concretização de uma idéia, a tradução em termos volitivos dessa idéia ou tese. A vontade não é a idéia... Exercer uma vontade significa desejar alguma coisa, a qual deverá necessariamente ser concreta... E da idéia central da peça deduzem-se as idéias centrais de cada personagem.... A idéia central da personagem deve corresponder ao "objetivo principal" stanislavskiano: idéia e vontade são uma e a mesma coisa, a primeira sob a forma abstrata e a segunda sob uma aparência concreta ${ }^{117 "}$.

Entretanto, segundo ele, a vontade da personagem só poderá movimentar a peça a partir do momento em que o ator desmontá-la e a enxergar como idéia. Para isso, a atuação terá de ser, em algum nível, capaz de conectar o particular ao geral. 0 que pressupõe uma atitude narrativa. É só partir da elaboração da idéia central da peça como um todo que cada ator poderá encontrar as idéias centrais de cada personagem. É necessário, segundo Boal, que o ator tenha em mente algo muito concreto, palpável, para que possa criar objetivamente seu personagem:

"Uma vez escolhida a idéia central da obra, deve a mesma ser absolutamente respeitada, para que todas as vontades cresçam dentro de uma estrutura rígida de idéias. Esta estrutura de idéias é o esqueleto. Por isso há que se estabelecer qual é a idéia central da peça (ou do espetáculo) e a partir daí deduzir as idéias centrais de cada personagem, de modo que essas idéias centrais se confrontem num todo harmônico e conflitual. (Idéia central= tese $x$

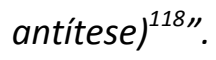

\footnotetext{
117 Boal, Augusto. 200 Exercícios e Jogos para o Ator e o Não-Ator com Vontade de Dizer Algo Através do Teatro. Rio de Janeiro: Civilização Brasileira, 1982, pp. 49, 50.

${ }^{118}$ Boal, Augusto. 200 Exercícios e Jogos para o Ator e o Não-Ator com Vontade de Dizer Algo Através do Teatro. Rio de Janeiro: Civilização Brasileira, 1982, pp. 50, 51.
} 
Através desse mecanismo, em que uma peça é vista como uma "estrutura de idéias", Boal parece acreditar ser possível produzir um olhar dinamizador sobre os materiais da peça, sejam eles mais tendencialmente épicos ou dramáticos.

O grau de abstração de seu modelo, porém, não esconde uma das principais contradições de seu projeto dramatúrgico: uma dialética geral do drama (baseada na ação livre e consciente) terá dificuldade de incorporar conteúdos que se referem a processos coletivos.

\section{A personagem sujeito e a personagem objeto}

Naquele momento histórico de fins dos anos 1950 e início dos anos 1960, em que a luta de classes acirrava-se no Brasil, era certo que a politização do Teatro de Arena levou seus integrantes a debater as dificuldades de um modelo dramático em que os indivíduos são capazes de seu destino tendo a história apenas como pano de fundo. Por outro lado, é possível imaginar que eles rejeitavam uma negação completa das possibilidades de ação livre, o que dentro daquela lógica representacional poderia ser paralisante.

Sendo assim, é evidente que o modelo do teatro épico de Piscator e dialético de Brecht se pôs como questão mais ou menos consciente para o Seminário de Dramaturgia, ainda que tenha havido ali uma dificuldade de incorporar padrões antiidealistas, frontalmente negativos em relação à tradição dramática. Essa questão, que 
pediria um estudo à parte, pois se desdobra na polêmica posterior de Boal com Anatol Rosenfeld em torno de Arena conta Tiradentes ${ }^{119}$, sugere que o Seminário foi um lugar de luta entre visões de teatro que se tornaram cada vez mais contraditórias (como se vê na cisão que gerou o CPC), mas que tinham como denominador comum o interesse pela dialética.

Pouco a pouco, ao que parece, os integrantes do Seminário passaram a se interessar também pelas personagens objetualizadas, figuras incapazes de autodeterminação moral, personagens que o autor francês Jean-Pierre Sarrazac definiu como os "Zé Ninguém ${ }^{120 " . ~ A o ~ a n a l i s a r ~ a ~ p e c ̧ a ~ W o y z e c k, ~ d o ~ a l e m a ̃ o ~ G e o r g ~ B u c h n e r, ~ e l e ~}$ descreve esse auto-consumo de um sujeito que não é mais sujeito:

"O sentimento trágico moderno nasce de uma dupla constatação: da forma mesquinha como o homem habita o mundo; do fato de que esse homem é, ele próprio, habitado por um poder estranho - a ideologia como forma de apropriação dos corpos.... Woyzeck tornou-se exemplo-tipo desta meditação sobre os dois aspectos de uma mesma alienação. A peça de Büchner faz a constatação de que o indivíduo, ao viver uma situação econômica e existencial que o faz descer a categoria do sub-humano, a um estatuto de dependência total, nem por isso encontra incentivo para uma revolta: anestesiado ou vítima de convulsões, contribui para a sua própria destruição ${ }^{121, \prime \prime}$.

\footnotetext{
${ }^{119}$ Essa polêmica está presente no livro de Anatol Rosenfeld, O Mito e o Herói no Moderno Teatro Brasileiro. São Paulo: Editora Perspectiva, 1996

${ }^{120}$ SARRAZAC, Jean-Pierre. O Futuro do drama. Porto: Ed. Campo das Letras, 2002, p. 121

${ }^{121}$ SARRAZAC, Jean-Pierre. O Futuro do drama. Porto: Ed. Campo das Letras, 2002, p. 121
} 
No momento em que a personagem chega a um "estatuto de dependência total" ela não tem mais condição nem sequer de revoltar-se, contribuindo para "a sua própria destruição". Mas, para que essa personagem possa existir na sua categoria de fantasmagoria, é necessário que se estabeleça uma nova forma, e que à sua volta o mundo também esteja nesse movimento de desagregação. O teatro épico constitui esse campo de pesquisa formal.

Em O Teatro do Oprimido, quando compara Brecht com Hegel na questão da personagem, Boal avança no problema, mostrando que as duas teorias batem de frente quanto à questão da liberdade do sujeito. Para a poética idealista, este nasce com configurações que são imanentes a uma certa "natureza humana". Já para Brecht, e para a tradição marxista de pensamento, o personagem, assim como o ser humano, não é nada a priori, pois serão as condições sociais que o moldarão, como comenta Boal:

" ...para todas as poéticas idealistas (Hegel, Aristóteles e outros) o personagem já "nasce" com todas as suas faculdades e propenso a certas paixões. Suas características fundamentais são imanentes. Para Brecht, ao contrário, não existe "natureza humana" e, portanto, ninguém é o que é porque sim! É necessário buscar as causas que fazem com que cada um seja o que $e^{122 \prime \prime}$

122 Boal, Augusto. Teatro do Oprimido e Outras Poéticas Políticas. Rio de Janeiro: Civilização Brasileira, 1980, p. 104 
Assim, nessa época, Boal já percebia a dificuldade de unir as duas teorias, pois o grau de contradição entre elas não era de ordem circunstancial, mas estrutural, o que impedia uma maior aproximação coerente entre elas, como constata:

"A poética marxista de Brecht não se contrapõe a uma ou outra questão formal, mas sim à verdadeira essência da poética idealista hegeliana, ao afirmar que o personagem não é sujeito absoluto e sim objeto de forças econômicas, ou sociais, às quais responde e em virtude das quais atua ${ }^{123 \prime \prime}$.

No momento do Seminário, porém, a percepção teórica sobre as imposições da forma dramática ainda não era percebida com toda a sua força, parecendo ser possível conciliar teatro épico e dramático numa dialética superior. De um ponto de vista prático, porém, as peças produzidas no período indicam o desejo de conteúdos novos, expondo sua necessidade de uma dialética mais materialista, de choque com formas pré-estabelecidas que remontavam a esquemas prontos da tradição burguesa.

\section{A difícil passagem do idealismo para o materialismo}

Dentre os integrante do Seminário, talvez tenha sido Oduvaldo Vianna Filho quem mais teve consciência crítica sobre as contradições do aprendizado do período:

\footnotetext{
${ }^{123}$ Boal, Augusto. Teatro do Oprimido e Outras Poéticas Políticas. Rio de Janeiro: Civilização Brasileira, 1980, pp. 99, 100
} 
"O Teatro de Arena continua a manter o homem como ele é, sem procurar discutir como ele não é. A perplexidade do homem diante da sociedade é espantosa. Ele pensa, age, sente em termos de indivíduo. O Teatro de Arena não procurou golpear e demolir o indivíduo, e jogá-lo dentro da massa e dos seus problemas e sentimentos como massa. A idéia de que o indivíduo desaparece pode assustar a pequena burguesia. Não assustará o proletariadoé a sua libertação e livrar do pesado fardo de indivíduo que carrega, retido mesmo no seio do problema do homem social. Chapetuba Futebol Clube tem o mesmo problema de Eles Não Usam Black Tie. O homem que pensa, que procura racionalizar, trai. Há um susto de teoria no Teatro de Arena, ele que põe uma teoria, ainda que simplista, do teatro brasileiro. A objetividade, o real, é confundido com sua descrição, não com sua síntese. As peças são sobre o homem consumido. Black Tie - uma greve- tudo se passa numa favela. Nunca se colocam os sentimentos e os critérios de valores para o homem dirigir a sociedade. Mostram-no sempre enquanto vítima- nunca enquanto agente de sua própria condição ${ }^{124 ” .}$

Nesta aguda reflexão, Vianinha sinaliza a real dificuldade da passagem do idealismo para o materialismo, das formalizações individualizantes para a representação dos coletivos, afirmando que o homem retratado nas peças do Seminário ainda era desenhado como indivíduo deslocado do papel social que o conforma e o molda. Ao mesmo tempo, a Vianinha não interessa a representação da pura vítima, do não-participante dessa dinâmica social.

A percepção posterior das limitações do drama para o Seminário não dá conta de explicar as muitas causas que dificultaram a produção de formas mais radicais de

\footnotetext{
${ }^{124}$ Vianinha, Quatro Instantes de Teatro no Brasil. in Peixoto, Fernando (Org). Vianinha. Teatro, Televisão, Política. São Paulo: Brasiliense. 1983, p. 51
} 
teatro dialético. As hesitações, compreensíveis, correspondiam a uma conjuntura histórica maior. Entretanto, mesmo em sua versão idealista, o estudo de dialética empreendido no Seminário de Dramaturgia foi mobilizador para uma geração, trazendo enormes avanços práticos que, inclusive, permitiram a avaliação crítica posterior.

Tal como formulada nos debates da época, a dialética era uma ferramenta muito geral, um conjunto de categorias que parecem estar mais próximas dos manuais de materialismo histórico. De qualquer modo, no pensamento dos artistas do Teatro de Arena, ajudava a desenvolver um olhar concretizador e o gosto pelas contradições e descrições baseadas na negação da negação, tal como nos princípios formulados por Engels:

"Quando se diz que todos os processos têm de comum a negação da negação, o que se pretende é englobar a todos, sob esta lei dinâmica, sem se prejulgar, no entanto, de modo algum, o conteúdo concreto de cada um deles. Esta não é a missão da dialética, que tem apenas por incumbência estudar as leis gerais que presidem à dinâmica e ao desenvolvimento da natureza e do pensamento... Negar, em dialética, não consiste pura e simplesmente em dizer não, em declarar que uma coisa não existe, ou em destruí-la por capricho. Já dizia Spinoza: Omnis determinatio est negatio, toda determinação, toda demarcação é, ao mesmo tempo, uma negação. ${ }^{125 "}$

Boal se inspira em passagens como essa, em seu estudo das leis dinâmicas da representação. A atitude científica avançada, contudo, às vezes esbarrava no

${ }^{125}$ Engels, Friedrich. Anti- Duhring. São Paulo: Paz e Terra, 1990, pp. 120, 121. 
cientificismo simplificador. Mais tarde o próprio Boal comenta o risco das generalizações, pensando nos padrões de estrutura dramática que utilizava:

"Queríamos refletir sobre uma realidade em modificação e tínhamos ao nosso dispor apenas estilos imodificáveis ${ }^{126}$."

Renata Pallottini em seu livro $O$ Que é Dramaturgia realiza uma das mais importantes sistematizações que permitem ver a técnica dialética praticada no Seminário. Seu contato com Boal foi na Escola de Arte Dramática. Ela ressalta que, daquele curso, contemporâneo do Seminário, "emergiu, então, para nós alunos e professor, um conjunto de Leis do Drama, extraídas de Hegel e de sua Lógica Dialética por Augusto Boal e aplicáveis ao drama aristotélico ${ }^{127 " . ~ B o a l ~ e s c r e v e ~ e m ~ c a r t a ~ p a r a ~}$ Pallottini, vinte anos depois:

"Pelo que eu me lembro, tentei adaptar, ou sistematizar, os conceitos hegelianos dentro das 4 leis da dialética e deu nisso:

1- Lei do Conflito;

2- Da variação quantitativa (ação dramática);

3- Variação qualitativa e

4- Interdependência ${ }^{128 "}$

${ }_{126}$ Boal, Augusto. Teatro do Oprimido e Outras Poéticas Políticas. São Paulo: Civilização Brasileira, 1980, p. 187.

${ }^{127}$ Pallottini, Renata. O Que é Dramaturgia. São Paulo: Brasiliense, 2006, p.70

${ }^{128}$ Pallottini, Renata. O Que é Dramaturgia. São Paulo: Brasiliense, 2006, p.70 
O mesmo parâmetro analítico animava os debates do Arena. As leis citadas por Boal faziam uso também da teoria de Lefévre, Stálin, entre outros autores materialistas. Engels aparece como uma das importantes influências não declaradas dessa teoria, segundo o dramaturgo Sérgio de Carvalho, em comentário sobre palestra de Lauro César Muniz (outro dos alunos de Boal que difunde suas reflexões pedagógicas):

"O método de Boal-Muniz é uma síntese que se assemelha à explicação que Engels dá sobre a ciência da mobilidade de Hegel. Num primeiro nível, as contradições gerais entre $A$ e $B$, duas personagens, ou dois grupos de personagens se dão como unidade em torno de um campo ou problema comum. Não se trata só do conflito de vontades opostas. A e B estão numa unidade contraditória em torno de uma questão comum, em interação problemática, na medida em que existem também contradições internas de lado a lado: " $A$ " não é uma identidade fechada, trava uma luta interna que dificulta sua ação com B, e vice-versa. Nos termos do mundo do Drama pré e pós burguês, isso pode ser lido como hesitação, contra-vontade ou contradever, até a conquista da decisão. O processo se dá em etapas. Segundo a terminologia clássica da dialética, ocorrem as variações quantitativas da interação. Em um determinado momento em que quantidade se faz qualidade, o salto transformador: a variação qualitativa. O pressuposto desse esquema de compreensão dinâmica das interações entre as personagens provém de Hegel: a "árvore que está aí e cresce" também realiza, em suas determinações, sua morte. "Toda determinação é uma negação" registra Engels no Anti-Duhring, repetindo Spinoza ${ }^{129 \prime \prime}$.

O relevante desse processo hoje é algo um tanto quanto impalpável. entusiasmo com o princípio dialético, foi, entretanto, liberador. A simples consciência

${ }^{129}$ Carvalho, Sérgio de. Encontro com Lauro César Muniz. In http://www.sergiodecarvalho.com.br 
do movimento gerado pelas contradições e negações inspirou o trabalho de escrita de uma geração, o que aparece na fala do dramaturgo Lauro César Muniz:

"O genial é que este sistema permite um desdobramento rico em possibilidades. Independente do que assimilei do Boal/Lawson, via Hegel, eu consegui descobrir muitos caminhos a partir do meu dia-a-dia de intenso trabalho na dramaturgia (novelas). Essa base é que norteou toda a nossa geração. Curiosamente, o próprio Boal não sistematizou, não escreveu a respeito, ficando tudo como um poderoso chip dentro de nós, onipresente, onisciente. É claro que tudo isso - é importante dizer - é um processo de trabalho que leva à comunicação. Colabora para gerar o fenômeno de comunicação dramática, mas, obviamente, não leva um autor a escrever melhor. Nenhum sistema gera qualidade artística. É, isso sim, uma ferramenta poderosa que favorece a comunicação ${ }^{130 "}$.

Com todo seu aparente esquematismo, surgia ali uma ferramenta de trabalho que motivou uma época a práticas avançadas de teatro, aliada à idéia de uma formação contínua, como afirma Sérgio de Carvalho: "São princípios aparentemente simples, mas vê-los expostos como se fossem ferramentas de um artesão, ajuda a compreender o trabalho teatral de uma época ${ }^{131}$.

E o processo reverberou por muito tempo não só no teatro, mas também no cinema e marcadamente na televisão, enquanto não se diluiu de vez o projeto temático nacional-popular.

\footnotetext{
${ }^{130}$ Muniz, Lauro César. O Ouro Verdadeiro. In. http://www.ar.art.br/

${ }^{131}$ Carvalho, Sérgio de. Encontro com Lauro César Muniz. In http://www.sergiodecarvalho.com.br
} 
Se a teoria tinha algo de fórmula, por outro lado, expandia-se ao se deixar modificar por um prática coletivizada e criativa, tornando-se principalmente um instrumento de trabalho, como avalia novamente Sérgio de Carvalho:

"Essa dialética do drama, como nos mostra Lauro César, não tem alcance universal, mas ajuda a compreender muita coisa boa e ruim na tradição hegemônica do drama ocidental. Descrita assim, apartada de conteúdos críticos, de temas históricos, pode se converter numa fórmula que no máximo serve de antídoto dinamizador à visão estática de certa cena lírica pós-dramática. Mas a geração de Lauro César estava interessada num Brasil popular, em ritmos anticapitalistas, o que impedia qualquer afastamento formalista das vibrações do mundo ${ }^{132 \prime \prime}$.

Por não incorrer no "afastamento formalista das vibrações do mundo", aquela geração de artistas da época do Arena abriu novos caminhos no que se refere à relação entre teatro e sociedade no país. E isso só foi possível como efeito de uma atitude experimental coletiva que sintetizava teoria e prática.

\section{A prática coletivista do Seminário}

$\mathrm{Na}$ prática dos encontros do Seminário, a dramaturgia era entendida como concreção de valores políticos e teorizantes. Cada texto era analisado como um

${ }^{132}$ Carvalho, Sérgio de. Encontro com Lauro César Muniz. In http://www.sergiodecarvalho.com.br 
trabalho dialético, o que pedia, no mínimo, uma união à interpretação. A prática do Seminário ia assim, muito além da mera aquisição de técnica literária. O texto era um meio de estudos para o grupo. Os integrantes permitiam-se levar ao palco peças que não tinham uma estrutura de obra acabada, mas cujo tema ou personagem central interessava do ponto de vista político. Não havia, nesse sentido, uma fórmula de resultados pré-estabelecida. A pesquisa se dava por tentativa e erro, como salienta Boal em uma entrevista da época:

"Não existe o que vulgarmente se chamou de playwriting americano aqui, né? Nós não tentamos fazer peça bem-feita, não tentamos descobrir uma maneira, um formulário de como escrever uma peça, uma receita, não tem nada disso. Quer dizer, nós procuramos justamente uma pesquisa." ${ }^{133}$

O Seminário superava, assim, a mera aplicação das estudadas leis do drama, em favor de uma perspectiva laboratorial. Mesmo aqueles que não tinham o intuito de seguir carreira como dramaturgo deveriam participar do processo, como mostra Guarnieri: "Houve muitas pessoas dando contribuições de extrema importância, mas sem escrever. Através de outras formas de trabalho. Foi um resultado indireto do Seminário ${ }^{134 ”}$.

Os sete textos produzidos a partir do Seminário aproximam-se muito do universo de atuação, pois ou foram escritas para os atores ou por eles. Flávio Migliaccio até

\footnotetext{
133 Boal, Augusto. Limites de Chapetuba. Atividades do Arena (Uma Entrevista). In Peixoto, Fernando (Org). Vianinha. Teatro, Televisão, Política. São Paulo: Editora Brasiliense. 1983, p. 41

${ }^{134}$ Peixoto, Fernando. Entrevista com Gianfrancesco Guarnieri. In Encontros com a Civilização Brasileira. Rio de Janeiro: Civilização Brasileira, 1978, p. 107
} 
então nunca havia escrito. Nelson Xavier e Milton Gonçalves tiveram seus estudos ali analisados, ainda que não encenados. Buscava-se uma atitude autoral do conjunto da equipe. Milton Gonçalves comenta numa entrevista:

"Se queríamos descobrir a verdade de uma personagem brasileira, suas possibilidades de realidade, era preciso que os textos fossem paralelos nessa procura. Eu mesmo cheguei a escrever duas peças que foram discutidas no Seminário. Nunca havia pensado em escrever antes disso" ${ }^{135}$.

A grande descoberta do Seminário era simples e rara: o trabalho do dramaturgo é sempre coletivo, mesmo que escreva em casa. Vianinha exemplifica a dinâmica dessa escrita processual e coletivizada que viria a formar sua visão de arte:

“... Eu consegui através do processo, de ver o Boal dirigindo uma peça minha, sentir muito de perto os defeitos dela, suas qualidades. Onde ela funcionava, onde ela se desenvolvia, onde ela brecava. E, ao mesmo tempo, o trabalho em equipe do Teatro de Arena (porque essa peça no Seminário de Dramaturgia passou por quase sete versões), isso tudo através da equipe discutindo permanentemente cena por cena, idéia por idéia, problema, por problema... "136

\footnotetext{
${ }^{135}$ Gonçalves, Milton. Um Depoimento. in Dionysos, número 24, Rio de Janeiro: Ministério da Educação e CulturaFunarte, 1978, p. 93

${ }^{136}$ Vianinha. Limites de Chapetuba. Atividades do Arena. (Uma Entrevista). In Peixoto, Fernando (org.) Vianinha. Teatro, Televisão, Política. São Paulo: Brasiliense, 1983, p. 39.
} 
Interessava então não exatamente a qualidade estética, mas um valor extraestético capaz de expressar a necessidade de produzir a peça. Com o passar do tempo, o grupo decidiu radicalizar a proposta de dar lugar a autores nacionais inéditos, só encenando as primeiras peças destes. ${ }^{137}$ Ao mesmo tempo em que se agudizavam as contradições do sentido político e social do projeto, parte do grupo descobria-se ali como um "autor profissional", o que reaviva a velha contradição de uma companhia experimental existir dentro do sistema comercial das artes, questão que se aponta na fala de Guarnieri, anos depois:

"A grande vantagem era que o Seminário pertencia a uma empresa. Ou seja, discutia-se textos para montar textos. A gente queria material para produzir. O sujeito não estava lá apenas para discutir por discutir. Não era uma especulação meramente cultural. O sujeito acabava sendo montado. Às vezes até contra posições, a gente acabou encenando coisas de que não gostava muito, mas achava que tinha que dar um significado prático e concreto ao Seminário. Deu muito banzé lá dentro por causa dessa posição. Mas havia a necessidade desse tipo de disciplina e de opção. Lançamos muita gente. E isso passou a influenciar a vida do teatro brasileiro, o processo teatral paulista mais diretamente. O autor nacional ganhou o palco. ${ }^{138 "}$

Enquanto existiu, o Seminário só fez aumentar as contradições, inquietações e descobertas criativas do Arena. Tudo era exaustivamente debatido, a ponto de causar

\footnotetext{
${ }^{137}$ Em entrevista à presente autora feita no Rio de Janeiro, em 10/2011, o ator Nelson Xavier afirmou que o projeto radicalizou-se e chegaram ao consenso de só montar por meio do Seminário primeiras peças de autores, nem a segunda valia. O projeto parece que vingou, pois as sete peças do Seminário seguem esse padrão.

138 Peixoto, Fernando. Entrevista com Gianfrancesco Guarnieri.In Encontros com a Civilização Brasileira. Rio de Janeiro: Civilização Brasileira, 1978, p. 104
} 
melindres em muita gente. Por outro lado, como lembra o ator Nelson Xavier, esta postura sempre contraditória permitiu que os participantes "abrissem a cabeça" para as especificidades da dramaturgia em particular e para o mundo em geral: "A gente passou a olhar tudo de uma maneira crítica, pensávamos em teatro 24 horas por dia, víamos estrutura dramática em qualquer conversa de bar."139 Guarnieri também descreve a mesma questão:

"As mais diferentes tendências se dispunham ao debate... Às vezes as discussões eram mais sobre posições político-ideológicas do que sobre as obras apresentadas. Outras vezes, uma peça era analisada de tal forma, quer dizer, inteiramente de um ponto de vista político-ideológico, a ponto da obra ficar deixada de lado... E se partia para uma discussão de posicionamento. Isso fez com que surgisse um racha no Seminário. A ponto dele ficar restrito aos elementos do próprio Arena. Foi um movimento necessário, a gente tinha que dar esse estímulo, essa incrementação. Deu resultados. ${ }^{140 "}$.

Os debates do Seminário pertencem a uma época do Arena de extrema inventividade no que se refere à interação entre arte e política. Para os convidados de fora, era difícil compreender a radicalidade das questões levantadas pelo grupo. A lenda de um déficit estético nos debate é, contudo, posterior. E foi fortalecida pelo depoimento daqueles que se sentiram rejeitados pela dinâmica do grupo, como o jornalista Álvaro de Moya, que assim descreve sua participação no Seminário:

\footnotetext{
${ }^{139}$ Entrevista concedida pelo ator Nelson Xavier à presente autora. Rio de Janeiro, 25/10/2011.

${ }^{140}$ Peixoto, Fernando. Entrevista com Gianfrancesco Guarnieri.In Encontros com a Civilização Brasileira. Rio de Janeiro: Civilização Brasileira, 1978, p. 104
} 
"O Seminário teve uma importância muito grande, isso não se discute. Mas os debates não levaram a nenhum ponto positivo para os autores. 0 Goleiro, um script meu, foi apresentado ao Seminário recebendo muitas críticas. Em seguida, apresentei-o a um concurso e ganhei... Basicamente, as críticas não serviram para mudar nada no texto nem na minha maneira de pensar $^{141 "}$

Jorge Andrade foi outro autor que, segundo a memória oral de muita gente, teria ficado decepcionado com as críticas que recebeu ali ${ }^{142}$. Já Roberto Freire destaca a função pedagógica daquelas acaloradas discussões em sua formação de escritor:

"Minha peça tinha um personagem que era um revolucionário cristão. E o pessoal não gostou nada disso, pois os revolucionários só podiam ser marxistas. As críticas foram tão violentas... que eu acabei por entender o porque do teatro que eles queriam fazer... Mais tarde aproveitando muito do que foi dito, fiz uma nova versão da peça. Eles estavam precisando de textos ...que mantivessem o conteúdo ideológico e revolucionário proposto pelo grupo, com personagens saídos do povo. E a minha peça se passava entre ferroviários e pizzaiolos...Quando fui ver os ensaios descobri que poderia ser um autor de teatro... E fiquei eternamente grato, mesmo depois de ter levado tanta porrada na primeira versão... mandei uma carta ao José Renato, dizendo

\footnotetext{
${ }^{141}$ Moya, Álvaro de. In Dionysos, número 24. Rio de Janeiro: Ministério da Educação e Cultura- Funarte, 1978, p. 72.

${ }^{142}$ Há informações sobre a presença de Jorge Andrade em diferentes relatos dos integrantes do Arena: de José Renato Pécora. In Ciclo de Palestras Sobre o Teatro Brasileiro. Rio de Janeiro: MINC-INACEN, 1984, pp. 26, 27. Outra de Guarnieri em Peixoto, Fernando. Entrevista com Gianfrancesco Guarnieri.In Encontros com a Civilização Brasileira. Rio de Janeiro: Civilização Brasileira, 1978, p. 103, entre outros.
} 
que eles não tinham idéia do bem que faziam ao possibilitar o surgimento de um novo autor. ${ }^{143}$

\section{Um caminho aberto}

Mais do que o estudo da dialética aplicada ao teatro, a contribuição modelar do Seminário se forma a partir de sua mobilidade constante entre aprendizagem e produção, entre teoria e prática, entre arte e história.

Sua substância ideológica provinha do ideário nacional-popular, mas sempre na perspectiva livre em que o pensamento não pode ser apartado de uma prática que 0 redimensiona, nos moldes da definição da filósofa Marilena Chauí:

"À primeira vista parece que o nacional-popular é algo evanescente, como se cada maneira de defini-lo o arrastasse na direção de outras maneiras de concebê-lo, como se não pudéssemos agarrá-lo de uma vez por todas. Na verdade, as oscilações de sentido indicam o óbvio, isto é, que não estamos diante de uma substância material ou espiritual, e sim perante práticas historicamente determinadas; ou seja, o nacional e o popular não são coisas dadas nem idéias, mas práticas sociais e políticas. ${ }^{144 "}$

\footnotetext{
${ }^{143}$ Freire, Roberto. Entrevista com Roberto Freire. In Almada, Izaías. Teatro de Arena. Uma Estética de Resistência. São Paulo: Boitempo Editorial, 2004, pp. 90, 91. Freire teve duas peças montadas pelo Arena, Quarto de Empregada, encenada no Teatro de Segunda-Feira e Gente como a Gente. No Teatro de Segunda-Feira o Arena apresentava peças que não dava conta de pôr em sua programação normal, foi nesse programa que Vianinha teve seu texto Bilbao, Via Copacabana, encenado em 1959, mesmo ano de estréia de Chapetuba Futebol Clube, também de sua autoria.

${ }^{144}$ Chauí, Marilena. Sobre o Nacional e o Popular na Cultura. In Cidadania Cultural. O Direito à Cultura. São Paulo: Fundação Perseu Abramo, 2010, p. 27
} 
Por conta dessa autocrítica constante é que não se pode isolar uma parte do projeto do grupo sob o signo do dogmatismo. Os integrantes do Arena tentavam com sua prática teatral desnudar as diferenças de classe e as fissuras sociais do país ${ }^{145}$ também presentes no mundo da cultura, o que levaria o próprio grupo a rachar diante de um aprendizado que impunha a todos uma reflexão sobre a função social do teatro. A radicalização da postura de Vianinha e de Chico de Assis que os conduz ao CPC é, entretanto, uma conseqüência de um trabalho anterior. Tanto das excursões com as peças nacionais que encenam por meio do Seminário ${ }^{146}$, quanto do efeito modelar de uma peça radicalmente épica como Revolução na América do Sul, de Boal, que teve sua estréia no Rio de Janeiro ${ }^{147}$.

É importante ressaltar que essa ruptura de certo modo construída pelo Seminário não se deu apenas por conta das divergências sobre o público a alcançar, questão que tantas vezes aparece nas avaliações sobre a época. Apesar de ser uma

\footnotetext{
${ }^{145}$ Esse viés será apontado pela filósofa Marilena Chauí, em seu estudo sobre o nacional-popular na cultura: “... a imagem da unidade social trazida pelo Estado também pode ser negada pelo nacional-popular e não apenas afirmada por ele. Essa negação ocorre quando o nacional reenvia à nação como unidade, mas o popular reenvia à sociedade, e portanto, à divisão social das classes e não mais ao povo como unidade jurídica e política. Enquanto, no caso anterior, a unidade do nacional absorvia a divisão entre popular e não-popular na identidade nacional e no Estado nacional, agora a divisão das classes impede essa absorção. É esse o sentido que Gramsci atribuía ao nacional-popular como contra-hegemonia". Sobre o Nacional e o Popular na Cultura. In Cidadania Cultural. $O$ Direito à Cultura. São Paulo:Fundação Perseu Abramo, 2010, p. 26

${ }^{146}$ É a atriz Lélia Abramo quem descreve a extensa viagem: "Após meses de sucesso absoluto no Teatro de Arena, iniciamos nossa aventurosa e quase rocambolesca temporada pelo interior e litoral do estado de São Paulo, onde nos apresentamos em cerca de 20 cidades, como Araçatuba, Araras, Bauru, Campinas, Graça, Lins, Marília, Mineiros do Tietê, Ourinhos, Penápolis, Presidente Prudente, São José do Rio Preto, Santos, Taubaté. Fizemos ainda espetáculos em algumas cidades de outros estados, como Poços de Caldas e Araxá, em Minas Gerais; Porto Alegre, no Rio Grande do Sul, e em muitas outras. Em algumas tivemos de encenar mais de uma vez o espetáculo devido às filas enormes, com o público à espera do lado de fora do teatro". Abramo, Lélia. Vida e Arte. Memórias de Lélia Abramo. São Paulo: Fundação Perseu Abramo, 1997, pp. 151, 152.

${ }^{147}$ Boal comentará a viagem ao Rio de Janeiro em suas memórias. Boal, Augusto. Hamlet e o Filho do Padeiro. Rio de Janeiro: Editora Record, 2000, pp. 173, 174.
} 
crítica constante de Vianinha, o Arena já vinha conquistando uma diversificação do público com quem dialogava. ${ }^{148}$ Talvez a maior divergência surgisse no ponto em que o debate sobre função da arte conduz ao debate sobre o modelo formal, como comenta Guarnieri, anos depois:

\begin{abstract}
“... no Arena em relação ao CPC, o que discutíamos muito era o seguinte: éramos contra um tipo de dramaturgia panfletária, que era chamada de popular, mas para nós não era popular, era só panfleto mesmo, despido de qualquer atrativo, de qualquer conseqüencia efetiva em termos de teatro. $O$ que se deveria procurar não era a dramaturgia imposta de cima para baixo, como eles faziam, paternalista. E anti-democrática mesmo, achávamos também. No Rio eles pensavam o contrário. Isso gerou uma série de polêmicas interessantes, mas de nível... No geral você não pode jamais esquecer que, fundamentalmente, qualquer forma de expressão artística exige uma dedicação a ela, um cuidado com ela. Com a própria forma de expressão, sim, porque é aí que ela adquire força para atingir ${ }^{149 "}$.
\end{abstract}

Enquanto Guarnieri se valia de um argumento dualista para rejeitar como "panfletárias" as novas experiências formais épicas ensejadas pelo Seminário, Vianinha enxergava ali um novo caminho de unidade dialética entre arte e política, que tantos frutos deu no CPC. Não só Revolução na América do Sul, mas também O Testamento

\footnotetext{
${ }^{148}$ A pesquisadora Leslie Damasceno comenta a questão: "Criam diferentes subgrupos dentro do teatro e passam a encenar panfletos e peças em subúrbios, auditórios e sindicatos". Damasceno, Leslie Hawkins. Espaço Cultural e Convenções Teatrais na Obra de Oduvaldo Vianna Filho. Campinas: Editora da Unicamp, 1994, p. 84.

${ }^{149}$ Peixoto, Fernando. Entrevista com Gianfrancesco Guarnieri. In Encontros com a Civilização Brasileira. Rio de Janeiro: Civilização Brasileira, 1978, p. 107
} 
do Cangaceiro, de Chico de Assis, abandonavam o mundo do drama em favor de uma linguagem marcadamente épica e popular.

Guarnieri é quem aponta o vinculo indissolúvel entre as pesquisas do Seminário e do CPC:

"O Seminário pode ter sido, por exemplo, o primeiro espectro desta mistura de tendências que vai aflorar no CPC. Muitas das posições discutidas no Seminário passam a ser o centro de debates internos do CPC e muitas passam a ser a linha de ação do movimento ${ }^{150 "}$.

A verdadeira dialética do Seminário haveria de se realizar fora dele, num lugar em que o conteúdo e a forma teatral uniam-se dialeticamente, em que a história deveria ser produzida de modo livre. O drama era, para isso, uma técnica insuficiente. Abria-se de vez a necessidade de uma encenação épico-dialética conectada ao momento brasileiro. Se é verdade que Brecht, com sua negatividade radical, não era um modelo fácil a ser adotado num país que há pouco realizava seus primeiros dramas, eram também verdade que uma teatralidade dialética e popular deveria ser inventada. Foram essas as coordenadas que o Seminário forneceu ao CPC, gerando uma nova pesquisa laboratorial nas ruas que seria interrompida com o golpe de 1964 .

\footnotetext{
${ }^{150}$ Peixoto, Fernando. Entrevista com Gianfrancesco Guarnieri.In Encontros com a Civilização Brasileira. Rio de Janeiro: Civilização Brasileira, 1978, pp. 106, 107
} 


\section{Capítulo 4}

\section{Apontamentos para uma nova dramaturgia}

A produção do Seminário de Dramaturgia do Teatro de Arena efetivamente encenada consiste em um conjunto de sete peças, montadas entre os anos de $1959 \mathrm{e}$ 1961. São elas:

1- Chapetuba Futebol Clube, de Vianinha (estréia em março de 1959),

2- Gente Como a Gente, de Roberto Freire (estréia em julho de 1959), 3- A Farsa da Esposa Perfeita, de Edy Lima (estréia em outubro de 1959),

4- Fogo Frio, de Benedito Ruy Barbosa (estréia em abril de 1960),

5- Revolução na América do Sul, de Boal (estréia em São Paulo em setembro de 1960),

6- Pintado de Alegre, de Flavio Miggliaccio (estréia em janeiro de 1961),

7- O Testamento do Cangaceiro, de Chico de Assis (estréia em julho de 1961).

Para se entender essa produção é preciso considerar seu contexto experimental, pedagógico e produtivo. São antes de tudo tentativas, apontamentos para uma nova teatralidade que estava em debate no grupo naquele momento. Se lidos como textos prontos sobressaem apenas suas insuficiências, e se perde de vista seu caráter de material para uma modalidade de encenação laboratorial que justificava, então, sua utilidade como motor para um trabalho futuro.

Do ponto de vista de gêneros, pode-se dividir o conjunto entre três tendências, que em alguns casos se confundem: o drama social, a farsa popular e o teatro épico. É 
significativo que tenha sido Augusto Boal quem realize a maior recusa ao modelo dramático, questão critica de fundo do Seminário. Revolução na América do Sul é talvez a peça mais narrativamente experimental do período e pode ser considerada um símbolo de salto qualitativo que mantém relações com a cisão que gerou o CPC.

O que se pretende aqui não é a análise detalhada dessas peças, mas a formulação de apontamentos sobre sua interação dialética com uma pesquisa cênica que alimentou a imaginação de uma época.

\section{Chapetuba e a crise do drama social}

$\mathrm{Na}$ medida em que o Seminário decorre do sucesso de Black Tie, é compreensível que vários de seus integrantes tenham almejado escrever um drama social brasileiro. Tinham à mão os instrumentos técnicos do curso de dramaturgia e parecia então ser suficiente aplicá-los a uma temática mais popular. Foi essa a principal tendência formal das peças do Seminário, com maior presença no início dos debates. Quatro das peças encenadas ali pertencem a esse gênero: Gente como a Gente, Fogo Frio, Pintado de Alegre e aquela que é a melhor realização no padrão, Chapetuba Futebol Clube. 
O processo de elaboração de Chapetuba se deu por meio das discussões que ocorreram no Seminário, a partir das quais a peça foi reescrita diversas vezes. Mesmo antes disso, em 1958, Chapetuba já havia sido lida na $\mathrm{EAD}^{151}$.

Por ser a peça imediatamente posterior a Black Tie, Chapetuba tinha uma grande responsabilidade: não só dar prosseguimento ao projeto dialético do Arena, como aprimorá-lo e dar senso de unidade a este. Havia essa expectativa em relação à peça, ao mesmo tempo em que ela confirmava a politização dos temas do grupo, como aponta Maria Silvia Betti:

"Se, por um lado, o texto de Vianinha é fruto de um trabalho mais seletivo de elaboração (em relação a Eles não Usam Black Tie), é a prática que irá, por outro lado, conferir-Ihe sua feição final- entenda-se por prática tanto o sistema de crítica colegiada que Boal adota para discussão dos textos, quanto o próprio treinamento dos atores e autores, levando-os à observação ativa de comportamentos e características psicológicas e sociais, nas ruas dos subúrbios, nas saídas das fábricas e de estádios de futebol ${ }^{152 "}$.

Chapetuba nasce assim, como um trabalho já modelar para o encaminhamento do próprio Seminário de Dramaturgia. Para que se entenda a força do seu conteúdo é

\footnotetext{
${ }^{151} \mathrm{~A}$ leitura da peça deu-se em uma atividade extra-curricular, segundo a lista destas atividades presente no livro de Armando Sérgio da Silva: "A simples enumeração de algumas destas atividades extra-curriculares servirá para aquilatar seu nível e importância: 1958: ... leitura da peça Chapetuba Futebol Clube, pelo autor Oduvaldo Vianna Filho". Silva, Armando Sérgio da. Uma Oficina de Atores. A Escola De Arte Dramática de Alfredo Mesquita. São Paulo: EDUSP, 1989, p. 68.

${ }^{152}$ Betti, Maria Silvia. Oduvaldo Vianna Filho. São Paulo: EDUSP, 1997, pp. 49, 50
} 
necessário atentar para o momento histórico no qual foi encenada, após a euforia com a vitória na Copa do Mundo de futebol. ${ }^{153}$

Vianinha aproveita-se desse "momento propício" para colocar em cena o avesso da "paixão nacional", a partir das tramas políticas e de interesses econômicos escondidos entre os contratos de jogadores, de federações, de patrocinadores, das concessões para a televisão e rádio e da cobertura da mídia.

$\mathrm{Na}$ peça vemos o time Chapetuba, de uma pequena cidade homônima, envolvido com a final de um campeonato que pode levá-lo à primeira divisão. Entre os jogadores destaca-se Maranhão, que está em final de carreira, e recebe uma proposta de suborno para dar a vitória ao time rival, Saboeiro.

A ação observa o processo de boa e má consciência de Maranhão, que a todo momento é tentado por Benigno, enviado do time rival, representante de uma cidade mais desenvolvida e rica. O dilema de Maranhão se dramatiza à medida que ficamos sabendo que ele está endividado e já aceitou propina em outra ocasião. Em paralelo a essa trama central, desenvolvem-se diversas sub-tramas, vividas pelos demais personagens: os jogadores Zito, Bila, Cafuné e Paulinho; a funcionária da pensão em que o time se hospeda, Fina; o dirigente Pascoal, o dono da rádio local, Eunápio, e Durval, técnico e jogador do time, que também passa por um teste de consciência, pois foi chamado pelo Flamengo para voltar a jogar.

153 "O momento era propício, pois um ano antes a seleção vencera na Suécia, o campeonato mundial, o que sem dúvida, só fizera alentar as expectativas nacionalistas. A nação, que se propusera avançar cinqüenta anos em cinco com os planos de metas do governo JK, possuía em seu bojo, o termo comum e democratizador de um esporte das massas. O país vibrava junto aos rádios, em casas e bares, diante da superioridade estratégica de seus jogadores, meninos provindos das várzeas, dos subúrbios, das favelas, para envergar, de forma tão bem sucedida, as cores nacionais. A escolha de Vianinha não poderia ser mais oportuna." Betti, Maria Silvia. Oduvaldo Vianna Filho. São Paulo: EDUSP, 1997, p. 50. 
O interesse de Vianinha em Chapetuba não estava só no retrato psicológico, mas na exposição do mecanismo econômico da compra e venda. Seu modelo dramático, entretanto, Ihe oferecia uma dialética intersubjetiva, em que as figuras estão em meio a conflitos internos e externos, figurando posições morais.

Vianinha interessava-se pelos mecanismos do futebol e se viu obrigado a sobrecarregar a estrutura dramática da peça com diversas sub-tramas de modo a abrir o campo do assunto. Para que não fossem apenas episódios arbitrários, fez com que fossem "amarradas" por meio da oposição que cada personagem faz a outro personagem, tentando promover as interações dialéticas, como sugere no texto do programa:

"Chapetuba F.C. encara o futebol ligado a todo processo humano e social de hoje. É a história do futebol- suas crônicas, sua dança, os gritos, a ciranda enorme ao lado do comércio puro e simples, da barganha, do interesse pequeno, do suborno negado e difuso. Esta coexistência dramática que mente a pureza do futebol explode na vida de um punhado de homens. Onze. De um lado- Durval, Maranhão, Pascoal, Benigno, céticos, deturpados, comidos por suas próprias vidas. Gente que aceita o estabelecido, que admite o antecipado. Luta, se revolta, mas partiu aceitando. Deste outro lado- Cafuné, Zito, Bila, Fina, pesados de sonhos, começando hoje, que puros, simples, não sabem ver. Desesperam, procuram e choram ${ }^{154 "}$.

\footnotetext{
${ }^{154}$ Vianna Filho, Oduvaldo. Programa da peça Chapetuba Futebol Clube, 1959, p. 8 O curioso é que neste texto do programa da peça, o autor fala em onze personagens, a peça tem dez, e cita apenas oito, deixando de fora Paulinho e Eunápio, o primeiro é um dos mais ingênuos da trama, e o segundo detém a rádio local e parece não ter grandes pruridos éticos com os desvios que comete em pról de sua rádio.
} 
Apesar do esforço de fazer crescerem as contradições internas das personagens numa paisagem popular, predomina no texto o embate externo, o conflito mais dualista, tornado mais vivo por sua capacidade de escritor de observar detalhes e matizar comportamentos, como se nota no seguinte trecho:

"Maranhão- Olha aí... (Tira o cheque do bolso). Olha aí... Maranhão se vendeu, sim. Maranhão se vendeu!

Cafuné- Por que, Maranha? Por que?

Maranhão- Pensá nos outro? Quem pensa nos outro? Na hora de comê junto? Na hora de dá bom-dia.

Cafuné- Eu penso nocê, Maranha. Cê sabe disso...

Maranhão- Ninguém se diz... Nunca ninguém se fala aí... Agora? Agora é? Agora é que tem de pensá nos outros? ${ }^{155}$ ”

Esta é uma das cenas decisivas da peça, em que Maranhão assume que "se vendeu". Cafuné é ingênuo, tem princípios e crê na bondade alheia. Já Maranhão é desiludido, sem esperanças. Destrói não só as ilusões do outro jogador, como a sua própria imagem. Num jogo de espelhos, por meio da contenda verbal, as falas se tornam reflexivas, relativizando o maniqueísmo moral da imagem.

Para ampliar o modelo dramático, Vianinha teve que compor detalhes nos atos e falas das personagens. Criou assim uma espécie de movimento pendular entre o negativo e o positivo, de modo a reduzir a condenação da vilania ou a expectativa de heroísmo. A base estrutural, entretanto, é dualista, sendo organizada pelo drama de 
Maranhão. Diante dessa expectativa criada pela forma da intriga, entende-se a crítica feita por Sábato Magaldi, que considera as subtramas excessivas:

"O pecado de Chapetuba é de excesso... Nota-se que o autor se escravizou à noção de conflito, segundo a qual devem sempre estar contracenando opositores permanentes ou ocasionais ${ }^{156 \prime}$.

Por outro lado, a multiplicação dos conflitos revela outro esforço, o da representação da mola econômica diante do mundo dramático. Trazer os diferentes pontos de vista de um processo econômico e político maior era um dos objetivos centrais do autor, como comenta a pesquisadora Leslie $\mathrm{H}$. Damasceno:

"Essa crítica (de Sábato Magaldi, supra citada) sem dúvida é verdadeira. Por outro lado, por mais desajeitada que seja aqui a inclusão e a resolução de vários conflitos, a intenção por trás dessa inclusão é importante para se compreender a trajetória da obra de Vianinha. Em toda a sua carreira, no trabalho de caracterização, Vianinha se empenha em um esforço para incluir o maior número possível de pontos de vista. É uma questão de tentar incorporar diferentes atitudes culturais na tentativa de dar amplitude ao tratamento dos sistemas de valores de uma maneira em que o contraste entre os aspectos positivos e negativos de um sistema de valor implique as condições sociais e econômicas que forma aquele sistema ${ }^{157 "}$.

\footnotetext{
${ }^{156}$ Magaldi, Sábato. In Damasceno, Leslie Hawkins. Espaço Cultural e Convenções Teatrais na Obra de Oduvaldo Vianna Filho. Campinas: Editora da UNICAMP, 1994, p. 107.

${ }^{157}$ Damasceno, Leslie Hawkins. Espaço Cultural e Convenções Teatrais na Obra de Oduvaldo Vianna Filho. Campinas: Editora da UNICAMP, 1994, p. 107.
} 
A pesquisadora enfatiza a tentativa recorrente do dramaturgo em dialetizar os conflitos e pontos de vistas, ainda que em Chapetuba as dualidades predominem sobre a dialética.

A aparência de excesso surge como imperativo do drama, forma que só permite que a história seja contada linearmente, impedindo saltos temporais, ou cenas do passado. É nessa peça inaugural que o Seminário verifica a crise constitutiva do drama intersubjetivo sempre que ele almeja a representação de processos amplos do ponto de vista social ou psíquico.

Os problemas de desenvolvimento de Chapetuba, que têm sua origem na dicotomia entre forma e conteúdo, trouxeram a seu autor e ao grupo um consciência da questão que modificaria os rumos da pesquisa do Arena. Era uma passo, o que podia ser dado, dentro do projeto de pesquisa do Arena ${ }^{158}$. E seu autor tem clareza sobre as motivações do trabalho:

"Chapetuba F. C. tem defeitos graves de ordem essencial, causados pela ingênua satisfação de muitas vezes permanecer no pitoresco, no detalhe digestivo. Mas Chapetuba F.C. tem enorme importância atualmente porque, além de nacional, foi escrita numa tentativa de superar o melodrama jornalístico, a denúncia de efetito, a fala vaiza. É cedo para um resultado

\footnotetext{
158 "O Seminário de Dramaturgia de São Paulo, gestado no Teatro de Arena, mesmo incipinete, de calças curtas, é aquele tímido início que pode resultar na deflagração do salto qualitativo... A certeza do caminho escolhido dá fôlego vivo ao espinhoso auto-didatismo, desenvolve a capacidade auto-crítica. É aí que se situa Chapetuba F. C. nesta pesquisa, nesta vontade. Somente com realizações artíticas apoiadas na prática, é que poderemos chegar a formulações teóricas mais definitivas que permitam orientar e apressar o desenvolvimento do nosso teatro." Vianinha. programa da peça Chapetuba Futebol Clube, 1959, p. 8
} 
satisfatório total, mas fica a proposta. Tudo que na peça procura a reação fácil, o que fica superficialmente exposto, não é característico, é defeito ${ }^{159 "}$.

Em uma entrevista dada à época da estréia de Chapetuba no Rio de Janeiro, em $1960^{160}$, Augusto Boal defende a peça contra as críticas do próprio autor. O diretor concorda que há problemas, mas ressalta que eles se devem não aos excessos cronísticos, mas à relação entre forma e assunto, "que não permitiria uma análise mais profunda do desenvolvimento de um processo que o Vianna quis fazer na sua peça ${ }^{161 "}$.

Mesmo com os desvios épicos da estrutura do drama (as cenas do rádio de pilha, que faz as vezes de narrador), é uma peça em que o mundo coletivo e exterior depende do dialogo intersubjetivo para entrar em cena. As personagens têm que dar conta de uma crise que as ultrapassa por meio de suas falas. Vianinha não seria o mesmo depois da experiência e o próprio Seminário teria que aprender a representar no teatro os processos históricos e sociais. Maria Silvia Betti assim comenta a questão:

"Seria impossível abordar o futebol sem dispor de elementos para aprofundar o exame das questões que o condicionavam; essas condições, porém, pertenciam ao domínio das relações de produção, e por isso mesmo encontravam-se fora e além do escopo do que era trabalhável dentro do modelo dramático praticado. Dar-se conta disso representou, para Vianinha, a sua iniciação como dramaturgo e como pensador das questões sociais $e$ políticas do país sob o prisma do teatro; procurar ir além do impasse resultante

\footnotetext{
${ }^{159}$ Vianinha. programa da peça Chapetuba Futebol Clube, 1959, p. 8

160 Boal, Augusto. Limites de Chapetuba. Atividades do Arena (Uma Entrevista). In Peixoto, Fernando (org.) Vianinha. Teatro. Televisão. Política. São Paulo: Brasiliense, 1983, p. 89.

${ }^{161}$ Boal, Augusto. Limites de Chapetuba. Atividades do Arena (Uma Entrevista). in Peixoto, Fernando (Org). Vianinha. Teatro, Televisão, Política. São Paulo: Brasiliense. 1983, p. 42
} 
constituiu-se no caminho que ele viria a trilhar, desse momento em diante. Sob esse ponto de vista, "Chapetuba Futebol Clube" contém um elemento chave para a discussão do teatro de Vianinha, pois permite entender-se o processo de reflexões acerca da relação entre forma e matéria representada ${ }^{162 "}$.

A questão de estudar o teatro além do drama torna-se central para o autor a partir de então. E a discussão estético-política ganha cada vez mais espaço dentro do Seminário de Dramaturgia. E em vista da dificuldade de resolução imediata para o problema, era possível pelo menos valorizar as descobertas temáticas. E caberia à encenação resolver impasses e insuficiências ainda maiores de tentativas menos complexas do que a de Vianinha.

\section{Gente como a Gente}

Gente como a Gente, de Roberto Freire, teve sua estréia em julho de 1959, quatro meses depois da peça de Vianinha. Sua ação se passa no bairro do Brás, em São Paulo. As personagens são trabalhadores e vivem às voltas com questões sociais: falta de perspectivas de emprego e de ascensão social, sonhos de melhoria de trabalho, dificuldade de estabilidade financeira em meio a reviravoltas sentimentais. A estrutura da peça é dramática com algumas pequenas tentativas de desvios narrativos. Entre elas, aquilo que o autor chama de "microcenas", que deveriam ocorrer

\footnotetext{
${ }^{162}$ Betti, Maria Silvia. Revisitando Chapetuba: uma análise de Chapetuba Futebol Clube. In Por uma militância teatral: estudos de dramaturgia brasileira do século XX. Campina Grande: Bagagem / João Pessoa: Idéia, 2005. p. 16
} 
simultaneamente no palco. No entanto, mesmo tentando quebrar a estrutura dramática, a peça é basicamente formada por cenas entre quatro paredes: telefônica, casa de João, casa de Gina, um galpão abandonado e o entorno de um sinaleiro de uma ferrovia, único local "aberto", mas que acaba por ser utilizado como qualquer outro local fechado.

A trama entrecruza a vida das personagens de maneira bem melodramática, por meio de intrigas de cunho emocional, interpessoal. Há como pano de fundo potenciais conflitos sociais que são apenas insinuados: um acidente de trem que matou trabalhadores; a exploração dos trabalhadores dessa ferrovia, a falta de condições de saúde. Os conflitos são enunciados por meio da figura de Ditão, ex-trabalhador da ferrovia que perdeu a mulher e o "gosto pela vida" por conta de um acidente. Mas não existe nada além de sutis insinuações desses conflitos públicos pois a menção é logo encoberta pelas várias sub-tramas melodramáticas: as mocinhas que morrem de amor ou os pais extremosos que impedem que a filha namore um rapaz que "não presta".

Não é portanto, na estrutura conservadora da peça, que o Arena conseguiu vislumbrar um meio de pesquisa dialética. Havia, sim, alguma novidade temática nos tipos populares brasileiros às voltas com questões pertinentes à classe trabalhadora do mundo das ferrovias. Havia o desejo de estimular um jovem autor. Mas a peça, ao que parece, servia sobretudo como material de trabalho para uma nova experimentação cenográfica, essa sim de ordem dialética. 
Em seu texto publicado no programa do espetáculo, Boal indica que era preciso evidenciar os limites ideológicos e contradições do texto através de um embate com a cena:

"Gente como a Gente apresenta uma visão católica de um problema social. Freire julga a verdade católica a única capaz de conduzir o homem à plenitude espiritual. Mas condena a condição atual de sua igreja, ora apática, ora reacionariamente dedicada à não participação social... Em torno dessa idéia central construímos o espetáculo. Antônio incorpora a tese. Os demais personagens, em especial João, as várias antíteses... Na interpretação procuramos fazer com que cada motivação de personagem (isto é-sua vontade exteriormente exercida) não resumisse todo o conteúdo psicológico desse personagem, mas fosse apenas a resultante exterior de um sistema de vontade opostas e interdependentes ${ }^{163 \prime \prime}$.

O comentário de Boal explicita sua leitura. Nas personagens dramáticas, deveriam ser destacados aspectos quase alegóricos, de modo a que o debate subjacente aflorasse. Numa leitura ligeira, a "visão católica de um problema social..." não está evidente ao público. O aumento da contraposição dialética entre as personagens - "Antônio incorpora a tese. Os demais personagens, em especial João, as várias antíteses." -deixa claro que a montagem deverá comentar o que no texto apenas se esboça, seu ponto de vista crítico.

A encenação de Gente como a Gente foi a primeira em que o Arena buscou a ajuda de profissionais especializados em cenário e iluminação com o intuito de uma

\footnotetext{
${ }^{163}$ Boal, Augusto. Programa da peça Gente como a Gente, 1959, p. 7
} 
parceria criativa mais experimental. E isso se deu por conta da necessidade prática demandada pela montagem:

“... A peça pedia cinco cenários. Como resolver cenografia exuberante em espaço de 25 metros?... No Arena cada diretor resolvia cenário e figurinos em feira-livre e ferro velho. Iluminava seus espetáculos na medida da sua intuição e dos watts disponíveis. Confessei incapacidade... Maria Teresa Vargas, nossa amiga, conhecia um jovem arquiteto, Flávio Império, que nunca tinha feito cenário, mas tinha vasto talento para pintar e construir com as mãos. Ao contrário de se espantar com a exigüidade, achou desafio. Foi me fazendo perguntas e quando me dei conta, eu estava falando e ele desenhando ${ }^{164}$. "

Boal começa ali uma notável parceria com Flávio Império que se estenderá por anos e auxiliará o grupo em seu projeto estético de uma teatralidade brasileira. A montagem dava ênfase à dialética entre os elementos da encenação. Flávio Império, ao invés de reafirmar os traços melodramáticos dos diálogos, trouxe para a cena um elemento que dava relevo à aridez da ferrovia:

"Flávio partiu de um módulo que esbatia o melodrama: o paralelepípedo. Tudo era paralelepípedo na cenografia: de todos os tamanhos, desde a mobília até os lados de cada prego da estrada de ferro. Diálogo doce, a cena se mostrava austera e rude ${ }^{165}$."

\footnotetext{
${ }^{164}$ Boal, Augusto. Hamlet e o Filho do Padeiro. Rio de Janeiro: Editora Record, 2000, p.171

${ }^{165}$ Boal, Augusto. Hamlet e o Filho do Padeiro. Rio de Janeiro: Editora Record, 2000, p. 171
} 
A cenografia elaborava, assim, um comentário contraditório sobre o drama encenado. A pesquisadora Iná Camargo Costa ressalta como o cenógrafo reverteu em seu favor o problema da exigüidade do palco: "No estudo daquele espaço, a grande percepção de arquiteto: o chão é a única referência a partir da qual se podem estabelecer as demais ${ }^{166 ” . ~ P a r a ~ q u e ~ a ~ e n c e n a c ̧ a ̃ o ~ d e i x a s s e ~ a i n d a ~ m a i s ~ c l a r o ~ s e u s ~}$ pontos de vista, faltava desenvolver a iluminação. Chamam Ziembinsky, que era segundo Boal, "doutor em iluminação", mesmo sem ter verba para pagá-lo ${ }^{167}$. E seu trabalho amplia o sentido de comentário cênico sobre o texto, reposicionando o melodrama como parte de um projeto crítico que extrapola as palavras do texto. $\mathrm{Na}$ lógica do Seminário, o processo era exposto junto com o resultado.

\section{A Farsa da Esposa Perfeita}

Em outubro de 1959, o trabalho do Seminário de Dramaturgia experimenta uma primeira mudança mais radical de gênero com a encenação de A Farsa da Esposa Perfeita, de Edy Lima.

\footnotetext{
${ }^{166}$ Costa, Iná Camargo. Um Enredo para Flávio Império. In Sinta o Drama. São Paulo: Editora Vozes, 1998, pp. 198, 199.

${ }^{167}$ Boal comenta a parceria: “No papel, eu fazia as marcações não invadirem áreas contíguas. Mas... na realidade, que fazer para que a luz não iluminasse espaços indevidos? Pedi socorro: Ziembinsky tinha vindo com uma companhia polonesa como iluminador, aqui se iniciou diretor... Não tínhamos verba para semelhante lumiar da iluminação. Envergonhados, mesmo assim, convidamos Zimba. Fascinou-se com o desafio... e começou a mexer nos refletores, fez buraco na platéia para meter refletor... e nós sem coragem de perguntar o valor do cachê. Zimba furou, pregou pregos, pediu que subíssemos na escada, abaixássemos a lâmpada, trocássemos o celofane azul, que o amarrotássemos para dar luz mais quente- não tínhamos gelatina, éramos assim de pobres! Zimba fez o ensaio de luz e mostrou a proposta para cada cena. Ficamos deslumbrados com seus efeitos simples e ricos. Perguntamos angustiados o preço: "Foi um prazer...". Muitas vezes- nem sempre- senti enorme solidariedade na classe teatral brasileira, que sabia ser unida e forte". Boal, Augusto. Hamlet e o Filho do Padeiro. Rio de Janeiro: Editora Record, 2000, pp. 171, 172
} 
$\mathrm{Na}$ retomada desse gênero clássico de comédia grossa, o grupo talvez enxergasse a possibilidade de um diálogo com formalizações populares. A peça de Edy Lima parte de um tema convencional, o adultério, de modo a explorar a paisagem local de uma ação situada na cidade de Bagé, na fronteira do Brasil com o Uruguai.

A peça gira em torno do casal Olália e Sirvano e das peripécias com os galos de briga mantidos pelo marido. Quando o galo adoece, uma semana antes da briga marcada, Sirvano pede ajuda à benzedeira da comunidade, Sia Noca, o que dá início a uma série de confusões, falcatruas e reviravoltas.

A trama farsesca é baseada em quiprocós e mal entendidos, estando grande parte do interesse na caracterização verbal, uma mescla de expressões gaúchas com a fala rebaixada e grossa dos tipos tradicionais populares, como se vê no trecho abaixo:

"Sirvano- Será crível, Olalia, nóis que nunca briguemo e agora tu faiz finca pé num assunto desses...

Olalia- E tamém essa socedade do rinhadeiro que tu feiz com o Zeca...

Sirvano- (Rindo). Sabe o que mais? Tu j'ouviu falar de muié que tem ciúme dos amigo do marido? É o teu causo, tu tem ciúme deles. (No fundo do pátio aparece Sia Noca).

Olalia- (Prepara o chimarrão, usando água na garrafa térmica e oferece a Sia Noca). É servida?

Sia Noca- (Aceitando o chimarrão). Gracias." ${ }^{168}$

${ }^{168}$ Lima, Edy. A Farsa da Esposa Perfeita. Porto Alegre: Editora Garatuja, 1959, pp. 34,35 
A tentativa de imprimir cor local feita pela autora parece ter sido o principal ponto de interesse do Seminário. Para Boal ela expandiu o horizonte do grupo no que se refere ao uso de sotaques e costumes brasileiros, como afirma em suas memórias:

"A peça... revelava realidade brasileira desconhecida- a fronteira. Não podíamos falar de São Paulo a vida inteira: Bagé era Brasil! Espanholado, entonces, e Che no diálogo, chimarrão na cuia, porém nosso Brasil, Che! Fui conhecer Bagé, gente que falava agalegado, bebendo chimarrão, calças largas parecendo saias baianas. Para mim realismo era o linguajar paulista- percebi a existência de outros Brasis." ${ }^{169}$

O Seminário adota, então, um projeto de ampliar seu conceito de representação brasileira. No texto do programa, Boal se vê obrigado a justificar a aparente fraqueza do texto. Estava em jogo, e era preciso deixar isso claro, um processo de aprendizado que mantinha relações com uma dinâmica histórica da dramaturgia mundial. Tinha, portanto, mais valor uma tentativa aparentemente arcaizante de um jovem autor nacional do que uma peça consagrada de uma tradição teatral estrangeira:

\footnotetext{
169 Boal, Augusto. Hamlet e o Filho do Padeiro. Rio de Janeiro: Editora Record, 2000, p. 172. Esse mesmo desconhecimento dos sotaques dos outros locais do Brasil gerou, uma década antes, uma grande polêmica quando do surgimento do TBC, pois até então a tradição teatral mantinha seu centro no Rio de Janeiro. Lá começou a criticar-se o sotaque dos atores paulistas como sendo influência dos diretores italianos, como Celi e Bollini, entre outros, como comenta o ator Paulo Autran: "Essa coisa de italianismo surgiu com os críticos cariocas. Quando eles ouviram os paulistas falarem em teatro pela primeira vez, acharam que o sotaque levemente italianado que uma grande parte dos paulistas têm, era influência dos diretores... E, então, erradamente atribuíram aos diretores italianos o sotaque italiano dos paulistas.... em São Paulo, uma grande parte da população tem sotaque italianado. Então, isso foi atribuído aos diretores, quando era dos atores mesmo...". Autran, Paulo. In Depoimento IV. Rio de Janeiro: SNT, 1978, p. 30.
} 
"Podíamos ter como diretriz montar o "bom teatro" ou o "teatro ótimo", estamos sobretudo preocupados com o significado do nosso trabalho. Significa muito montar um grande autor, mas significa mais iniciar a carreira de quem ainda não disse o que pensa, de quem ainda não se sabe até onde vai. Um espetáculo vale pelo que é, e vale pelo que significa... Significa mais explorar o futuro do que revelar o passado. Significa mais um talento jovem do que um gênio antigo. Significa que estamos indo para a frente e, por enquanto, não importa para onde. Por todos os caminhos: pelo morro carioca, por Chapetuba, pelo Brás ou por Bagé. Pelo naturalismo, pelo realismo teatral e poético, ou pela farsa. ${ }^{170 "}$.

O que não estava plenamente anunciado aqui era o mérito da peça em liberar o grupo do padrão psicológico do drama. Com toda idealização nacional-popular que pudesse ter sido invocada na época para fazer sobressaírem valores do texto, ganhava espaço uma procura de diálogo com formalizações populares, com base em temática brasileira. A forma popular seria um passo de afastamento da dialética do drama, rumo a outras possibilidade de interação históricas. Boal ressalta a ênfase na perspectiva didática que a encenação deveria ter, o que era outra forma de expor o processo crítico-pedagógico em curso no Seminário de Dramaturgia:

"Por que motivo havíamos de informar a nossa platéia da ira de Osborne contra a sociedade inglesa e não informá-la do carinho e da ironia com que Edy Lima encara a gente da sua terra? Para que fazer constar a decadência de New Orleans williamsiana, ignorando o otimismo farsesco

${ }^{170}$ Boal, Augusto. Programa da peça A Farsa da Esposa Perfeita, 1959, p.8 
bagéense? Pensando assim aqui apresentamos A Farsa da Esposa Perfeita, apresentamos Edy Lima ${ }^{171 " \text {. }}$

\section{Fogo Frio}

Ainda na linha dos dramas sociais inaugurada por Chapetuba, o Seminário produziu em abril de 1960 a peça Fogo Frio, de Benedito Ruy Barbosa. Assim como Roberto Freire, Barbosa não era um autor interno ao grupo, mas um jovem promissor que deveria ser estimulado a refletir politicamente sobre seus materiais. Sua peça retrata também personagens da classe trabalhadora. São colonos plantadores de café do Norte do Paraná, às voltas com as intempéries da natureza, como a geada à qual o título faz menção. Fogo Frio mostra as terríveis condições sociais impostas pelos donos da terra a esses trabalhadores.

O estilo da peça é realista e ela centra esforços na caracterização psicológica e no diálogo intersubjetivo de figuras pressionadas pelo contexto social. Há na peça tentativas de desvio do drama estrito: uma dos personagens foge da coerência psicológica, parecendo antes um tipo simbólico: é simplesmente chamado de colono, pois definido por sua função social. No programa da peça é descrito pelo autor como "um dos milhares de párias que labutam de sol a sol, plantando e colhendo em troca de nada ${ }^{172, .}$ Mesmo com esse esforço de representação das funções, a vida individual subjetiva gera sub-tramas que acabam por dominar a cena, lançando a temática social

\footnotetext{
${ }^{171}$ Boal, Augusto. Programa da peça A Farsa da Esposa Perfeita, 1959, p.8

172 Barbosa, Benedito Ruy. Programa da peça Fogo Frio, 1960, p. 4
} 
à condição de pano de fundo da ação. Essa adequação da peça aos preceitos dramáticos não era mera coincidência. Barbosa afirma no programa da peça que:

"Depois de ver Eles não Usam Black Tie, de Gianfrancesco Guarnieri, depois de ver Chapetuba Futebol Clube, de Oduvaldo Vianna Filho, compreendi que era real e palpável a tentativa do Arena, de fazer um teatro nosso, abordando nossos problemas, identificando-se com nosso povo. Daí à minha tentativa de participar dessa luta em prol de uma dramaturgia nacional, foi um pulo". ${ }^{173}$

Barbosa partiu de um modelo já estabelecido - o drama - que, no entanto, vivia uma crise gerada pelo próprio avanço da pesquisa laboratorial do grupo. Para enfrentar as limitações impostas pela forma, de novo será preciso recorrer a uma relativa epicização dos elementos cênicos.

No programa do espetáculo, Boal explicita as qualidades e defeitos do texto de Barbosa. Mostra que os integrantes do Arena tinham consciência dos problemas formais e que seu intuito ia além do palco:

\footnotetext{
"Benedito Ruy Barbosa é o quinto estreante a ser lançado consecutivamente pelo Arena. Nunca teve uma peça montada e essa é a primeira que escreveu. Tem, pois, as qualidades e os defeitos que se esperavam; muita sinceridade e muita coisa para dizer embora careça de maior permanência no teatro, maior conhecimento de seus problemas ${ }^{174 ”}$.
}

\footnotetext{
173 Barbosa, Benedito Ruy. Programa da peça Fogo Frio, 1960, p.4

${ }^{174}$ Boal, Augusto. Programa da peça Fogo Frio, 1960, p. 7
} 
Boal ressalta ainda três características da peça que justificam seu interesse: "1análise de um problema social, 2- reprodução de um ambiente rural e 3- estudo psicológico de alguns personagens típicos ${ }^{175, "}$.

A necessidade de superar os enunciados psicologizantes através de tipos sociais ou de outros recursos narrativos estava, ao certo, em pauta nas discussões do Seminário naquele momento. Por outro lado, o autor defendia sua construção ressaltando seu compromisso realista:

"Se denúncias existem em meu trabalho, não foram forjadas por mim. São frutos, simplesmente, da autenticidade que procurei dar à narrativa. Tudo o que se passa em "Fogo Frio" aconteceu e continua acontecendo neste Brasil. Famílias como a de Zeca existem muitas; famílias como a do Colono também ${ }^{176 \prime \prime}$.

A montagem de Fogo Frio foi realizada numa parceria do Arena com um grupo que estava no início de suas atividades, o Oficina ${ }^{177}$. Na ocasião, o Teatro de Arena estava em cartaz no Rio de Janeiro e não contava com atores em São Paulo para a

\footnotetext{
${ }^{175}$ Boal, Augusto. Programa da peça Fogo Frio, 1960, p. 7

${ }^{176}$ Barbosa, Benedito Ruy. Programa da peça Fogo Frio, 1960, p. 4

${ }^{177}$ Boal, Augusto. Hamlet e o Filho do Padeiro. Rio de Janeiro: Editora Record, 2000, p. 174. A parceria com o Oficina gerou outros trabalhos, como comenta o crítico Sábato Magaldi: "Augusto Boal orientou curso de interpretação do elenco do Oficina e dirigiu A Engrenagem, adaptada por ele e por José Celso da obra de Sartre, além de Um Bonde Chamado Desejo, de Tenesse Willians. E o Oficina montou de Boal, sob a direção de Antônio Abujamra, a peça José do Parto à Sepultura". Magaldi, Sábato. Um Palco Brasileiro. O Arena de São Paulo. São Paulo: Brasiliense, 1984, p.38.
} 
montagem. Ao mesmo tempo, àquela altura da crise do Seminário, Boal já não era um grande entusiasta do material. Seu esforço era o de manter vivo o trabalho teatral:

"Benedito Ruy Barbosa tinha escrito sobre geadas no Paraná, Fogo Frio. Alguns não gostavam e eu, se não morria de amores, levava em conta que o autor prometia. Era nossa missão ajudar dramaturgos a dar primeiros passos. Em São Paulo não me sobrara ator. José Celso Martinez Correa e Hamir Haddad dirigiam um grupo amador, Oficina... propus que se profissionalizassem no Arena. Aceitaram ${ }^{178}$

\section{Revolução na América do Sul}

A primeira peça que marca ruptura formal, indo diretamente para uma forma épica e assumindo a mistura de diferentes formatos foi Revolução na América do Sul, de Augusto Boal, que estreou em setembro de 1960. Quebrando a barreira da forma dramática houve nela uma inédita explicitação dos assuntos, principalmente em seu conteúdo político, agora enunciados claramente e não sendo "escamoteados" pelas histórias subjetivas dos personagens.

José Renato, diretor da montagem, comenta o quanto essa mudança formal foi discutida pelo grupo, que percebeu sua importância para a pesquisa dramatúrgica do Seminário:

\footnotetext{
${ }^{178}$ Boal, Augusto. Hamlet e o Filho do Padeiro. Rio de Janeiro: Editora Record, 2000, p. 174
} 
"Então, quase todos os nossos trabalhos eram, quase sempre, baseados na psicologia da personagem. Mesmo a pesquisa do gestual brasileiro e da linguagem brasileira assentava numa base psicológica. A partir da Revolução na América do Sul, resolvemos transpor essa barreira. Conscientemente. Eu tinha visto alguns espetáculos do Brecht na Europa, e nós discutimos a possibilidade de transpor a barreira psicológica, que, aliás, a gente já havia transposto em alguns espetáculos nossos, embora inconscientemente". ${ }^{179}$

Essa mudança de modelo rumo ao teatro épico se dá em um momento em que o Arena passava por outra grave crise financeira. Por conta disso, em 1960, Boal decide levar o grupo para o Rio de Janeiro, para arrecadar fundos ${ }^{180}$. Assim, uma parte da equipe fica em São Paulo, levando à frente a montagem das peças do Seminário, e outra parte viaja para o Rio, onde estréiam Revolução na América do Sul.

Revolução na América do Sul conta a trajetória de José da Silva, desde o dia em que sua mulher o obriga a pedir aumento até a sua morte. No estilo de uma peça brechtiana como Um homem é um homem, ela mostra uma jornada de desmontagem: a personagem vai se desfazendo ao longo da peça. Não há aqui psicologia, consciência moral, positividade. A medida negativa é utilizada pelo autor em todos os âmbitos da peça, a começar pelo título, que é uma espécie de "pista falsa", na medida em que a revolução está ausente da cena e os tais "revolucionários" não podem comparecer pois têm compromissos pessoais "mais importantes" como sair com a namorada:

\footnotetext{
${ }^{179}$ Pécora, José Renato. Ciclo de Palestras Sobre o Teatro Brasileiro. Rio de Janeiro: INACEN, 1984, p. 24

${ }^{180}$ Boal comenta a nova crise: "Na crise de 58 o Arena se salvou da falência com Black Tie. Agora- fins de 60- era necessário passo mais arriscado. Dividir o elenco, metade n'A Farsa (A Esposa Perfeita), de Edy Lima, metade, na aventura do Rio". Boal, Augusto. Hamlet e o Filho do Padeiro. Rio de Janeiro: Editora Record, 2000, p. 172
} 
"Revolucionário- Agora só falta marcar a data histórica para a nossa revolução.

Zequinha- Até a data já está marcada. Amanhã ao meio dia.

Revolucionário- Amanhã?

Zequinha- Ao meio dia em ponto. Vamos atacar o palácio do governo. Matar os vendilhões da pátria. Vamos fuzilar, enforcar.

Revolucionário- Amanhã eu não posso.

Zequinha- (Quebra o tom). Não pode? estação. ${ }^{181 "}$

Revolucionário- Meu pai embarca para Paris, tenho que levar ele na

Tendo como contraponto essa luta social não organizada, a jornada do trabalhador José da Silva é narrada do ponto de vista de sua completa dependência da função social. E quanto mais despossuído se torna, a ponto de perder a própria força de trabalho, mais José da Silva torna-se por excelência, uma alegoria do povo.

A crescente desintegração de José da Silva revela um processo de desumanização. Ele não é, entretanto, um tipo de farsa, ainda que tenha algo disso. É antes um herói negativo, em que todas as ausências como que se anunciam: de subjetividade, de consciência política e moral, de vontade livre. Boal parece ter pegado o modelo hegeliano de personagem-sujeito e tê-lo usado do avesso. Essa visão está sugerida por seu texto no programa da peça:

${ }^{181}$ Boal, Augusto. Revolução na América do Sul. São Paulo: Massao Ohno Editora, 1960, p. 43 
"Rejeitei a idéia de fazer dele ( José da Silva) o operário politizado, cônscio dos seus verdadeiros problemas e soluções. José apresenta apenas aspectos negativos do operário: todo o seu esforço converge para um almoço melhor e isso lhe basta ${ }^{182}$."

Mas para que uma personagem-objeto desse tipo possa existir, é necessário que outras personagens que constituem o universo da peça também funcionem na mesma chave:

"O mesmo ocorre com os demais personagens: o Líder é o político sempre desonesto, Zequinha ambicioso, o anjo sempre cobrador da Light. Sei que existem políticos honestos, como não ignoro alguns pontos necessários na introdução do capital estrangeiro. Mas não foi sobre isso que me dispus a falar $^{183 \prime \prime}$.

Não é mais o protagonista que organiza o mundo da cena, mas o conjunto das personagens e ações, sendo a própria negatividade a carecterística fundamental da relação entre palco e platéia: "Pelo visto a peça não contém nenhum personagem positivo, mas será necessário? O negativo já não contém em si o seu oposto ${ }^{184 "}$

Mesmo as personagens que encarnam a imprensa, o imperialismo e o capital, não surgem em cena como alegorias simples. Sua configuração é contraditória na medida em que seu gesto é sempre ambíguo. José da Silva aparece assim como o

\footnotetext{
182 Boal, Augusto. Texto do programa da peça Revolução na América do Sul, 1960, p. 4

183 Boal, Augusto. Texto do Programa da peça Revolução na América do Sul, 1959, p. 4

${ }^{184}$ Boal, Augusto. Programa da peça Revolução na América do Sul, 1959, p. 4
} 
operário aquém da luta de classes, a abstração necessária para a geração da riqueza capitalista, símbolo que se presentifica na cena de sua morte:

"Zequinha-... Mas se é verdade que tudo depende do operário, o que é que vamos fazer, já que esse morreu?

Líder-Parece que entramos bem.

Zequinha- Precisamos descobrir outro operário que é prá gente continuar roubando.

Líder-Claro que precisamos. operário?

Zequinha- (Observando o coveiro que cuida de José). Coveiro é

Líder-É. Coveiro é operário.

Zequinha- Então achamos. (Precipitam-se todos atrás do coveiro, que foge assutado $\left.{ }^{185}\right)^{\prime \prime}$.

Até em sua morte, ele não abandona seu papel social. Morto José da Silva, o povo seguirá como força de trabalho que sustenta o sistema.

Em sua circularidade, a peça é dividida em quadros, de ordem relativamente independente, destacáveis. Sua narratividade depende de uma cena musical, como comenta a pesquisadora Claudia de Arruda Campos: "Revolução é um musical de comicidade contagiante, mas anárquico e demolidor, violenta sátira da democracia populista, estruturada numa sequência de episódios que podem ser encenados separadamente ${ }^{186}$."

\footnotetext{
${ }^{185}$ Boal, Augusto. Revolução na América do Sul. São Paulo: Massao Ohno Editora, 1960, p. 102

${ }^{186}$ Campos, Cláudia de Arruda. Zumbi, Tiradentes. São Paulo: Perspectiva, 1988, p. 46.
} 
Boal constrói aquele que é o mais épico de seus textos numa dinâmica de absurdos. Em nenhuma outra ocasião o Arena produziu uma teatralidade tão livre das coordenadas dramáticas, como ele mesmo percebe no programa da peça:

"Quis escrever uma peça que não procurasse a análise de um personagem defrontado com um problema e essa tarefa teria que se socorrer de elementos técnicos trazidos pelo cinema, pelas formas épicas e pelo circo $^{187} . "$

Revolução na America do Sul, em sua negatividade radical, é a mais materialista das peças do grupo, fazendo do anti-idealismo um projeto estético, no que segue a tradição brechtiana. Foi um marco histórico para o Arena e para o teatro nacional como um todo. Apesar disso, em pouco tempo Boal não dá mais muita importância para os avanços conquistados com a peça, como comenta a pesquisadora Iná Camargo Costa:

“... Alguns anos depois, Augusto Boal não dava maior importância à sua peça, a ponto de não apontar nela qualquer atributo que a distinguisse do repertório da chamada "fase nacionalista" do Teatro de Arena. Sobre aquelas peças saídas do Seminário de Dramaturgia, Boal escrevia que seu estilo "pouco variava e pouco fugia do fotográfico" consistindo a sua desvantagem principal em "reiterar o óbvio". Mesmo indicando Sartre e Brecht como elaboradores de um caminho que se dispôs a seguir, no prefácio da peça, o autor não demonstra acreditar que fez alguma coisa propriamente nova na dramaturgia brasileira. Antes incorporando as críticas que há de ter recebido quando da

\footnotetext{
${ }^{187}$ Boal, Augusto. Programa da peça Revolução na América do Sul, 1959, p. 5
} 
encenação, Boal acaba enumerando como defeitos, entre outros reais, justamente os aspectos formais que concorrem para caracterizar a novidade $e$ as qualidades de sua peça ${ }^{188 \prime \prime}$.

Essa recusa do próprio autor a valorizar a peça tem inúmeras razões. Foi após sua estréia no Rio que, diante do panorama efervescente do pré-1964, Vianinha e Chico de Assis deixam o grupo para fundar o CPC, em diálogo com diferentes entidades culturais, como o Instituto Superior de Estudos Brasileiros (ISEB) e depois com a União Nacional dos Estudantes. Ao mesmo tempo, a montagem do texto $A$ Mais Valia vai Acabar, seu Edgar, aprofundava a linha materialista anunciada pela Revolução.

Em outro aspecto, a estrutura negativa da peça contradizia o modelo do herói moral que tanto interessava a Boal, sobretudo diante do propósito de deixar evidente a intenção política da cena, por meio da empatia, como nota a pesquisadora Nicole Oliveira:

"A idéia de criar uma personagem central negativa, como acontece na Revolução na América do Sul, partindo do pressuposto que "o negativo já contem em si o seu oposto", em pouco tempo deixa de ser o objetivo da dramaturgia de Boal. Pelo contrário, o autor passa a buscar uma personagem central positiva, que seja passível de identificação para o público, e que mostre

${ }^{188}$ Costa, Iná Camargo. A Hora do Teatro Épico no Brasil. São Paulo: Graal, 1996, p. 58 
de fato (e não leve a essa conclusão pelo distanciamento), que o mundo pode $e$ deve ser transformado ${ }^{189 \prime \prime}$.

Essa persistência do drama será o tema de um debate posterior, que mostra o quanto o modelo épico-dialético depende de uma crítica radical ao idealismo, coisa difícil para muitos artistas daquela década, em particular para Boal, que depois do golpe, no prefácio da peça Arena Conta Tiradentes, escreveu:

\begin{abstract}
"Brecht cantou: "feliz o povo que não tem heróis". Concordo. Porém nós não somos um povo feliz. Por isso precisamos de heróis. Precisamos de Tiradentes ${ }^{190 "}$.
\end{abstract}

De qualquer modo, Revolução na América do Sul é a primeira peça do Seminário em que o teatro épico se realiza no texto, numa combinação livre e inventiva de elementos capazes de concretizar uma história política.

\title{
Pintado de Alegre
}

Pintado de Alegre, de janeiro de 1961, tem o mérito de mostrar o quanto o trabalho de um ator paradigmático na história do Arena, Flávio Migliaccio, era de fato

\footnotetext{
${ }^{189}$ Oliveira, Nicole Alcebíades de. Estudo das técnicas do Seminário de Dramaturgia do Teatro de Arena: as tensões entre forma dramática e forma épica em Revolução na América do Sul. 2008. Iniciação Científica. (Graduando em Artes Cênicas) - Universidade de São Paulo. Orientador: Sérgio Ricardo de Carvalho Santos.

${ }^{190}$ Boal, Augusto. Quixotes e Heróis In Prefácio da peça Arena Conta tiradentes. São Paulo: Editora Sagarana, 1967, p. 56
} 
autoral. Sua peça, uma relativa e compreensível regressão dramática nos caminhos do Seminário, conta a história de uma família de classe baixa às voltas com seu dia-a-dia de dificuldades financeiras e sociais. A mãe, Amélia e seus três filhos tentam sobreviver na Vila Mazzei, bairro pobre da Zona Norte de São Paulo (apesar do autor não nomear a cidade). Além da família há outras personagens que passam pela casa apertada em que se concentra a peça. O mundo de fora é trazido para dentro da ação através de uma janela, por onde as personagens vêem o que acontece na vizinhança.

Hesitando entre a caracterização psicológica e a constituição de tipos sociais, a peça esbarra em estereótipos: a mãe zelosa, o filho mau caráter e vagabundo, a filha alienada, o filho trabalhador e sonhador. Uma relativização do padrão surge nos dois palhaços de um circo que vão se apresentar no bairro na mesma noite em que haverá o comício de um vereador.

$\mathrm{Na}$ medida em que foi escrita por um ator do grupo que na montagem dirigida por Boal também fez parte do elenco, tudo indica que os limites dramáticos foram expandidos por recursos de atuação, em diálogo com a cenografia de Flávio Império. É o que sugere o texto de Boal no programa, que considera a peça de um "realismo impressionista": o autor expõe os caracteres "por pinceladas" e não por inteiro. Boal compara-os ao tipo de Tchekcov no tocante a sua letargia. Rssalta que quando conseguem sair desse estado, as ações que efetuam são tão frágeis que a qualquer momento podem ser desfeitas:

"Seus personagens são... anárquicos, pouco capazes de afirmações. Suas débeis vontades desfalecem a cada momento, jamais desenvolvendo o mesmo tema ou idéia durante longo tempo. Abandonam problemas 
fundamentais por motivos fúteis, passando da intensa alegria ao total abandono, da seriedade a brincadeira. O estilo é atmosférico, o diálogo fragmentado e circular ${ }^{191 "}$

A precariedade dramática da peça, que de um certo ponto de vista pode ser considerada fraqueza de desenvolvimento, é virada pelo avesso por Boal, que parece ter vislumbrado aí um campo de interferência de uma concepção cênica capaz de dialetizar o material:

"Tendemos a recusar ou temer personagens fragmentados ou incoerentes. A técnica da pincelada desorienta. $O$ ator sente a descontinuidade da emoção, os saltos bruscos, a ausência de lentas transições. Seus apoios são poucos e breves. O próprio processo dialético de interpretação, muitas vezes foi substituído pela pura intuição. O estilo impressionista exige do ator a permanente vivência da personagem, pois só ela é capaz de criar a atmosfera da qual as várias cenas se sucedem sem muita sequência lógica, na qual cada cena deve valer por si mesma, independentemente da sua colocação no ato e na peça ${ }^{192 \prime \prime}$

Essa descrição reforça a idéia de que naquele momento, 1961, posterior à crise que gerou o CPC, Boal já estava interessado em modelos teatrais abertos, de ruptura até mesmo em relação às leis da dialética dramática.

\footnotetext{
${ }^{191}$ Boal, Augusto. Programa da peça Pintado de Alegre, 1961 p. 3

192 Boal, Augusto. Programa da peça Pintado de Alegre, 1961, pp. 3 e 4
} 
A forma da peça de Migliaccio, entretanto, era conservadora. Poderia ter havido uma divisão em quadros independentes que deixasse ostensiva a descontinuidade, técnica usual nos textos de Brecht, por exemplo. Cabia ao encenador, assim, interferir na estrutura:

\begin{abstract}
"A idéia central de Pintado de Alegre deriva não de uma discussão de idéias, mas da impressão global que o texto deve causar. Flávio Migliaccio, apresenta condições sociais das quais vários personagens tentam escapar. Cada um escolhe seu caminho diferente, e todos os caminhos são falsos... A peça narra essas tentativas de fugas todas fracassadas, todas negativas. Só as acusações são positivas nesta peça ${ }^{193}$."
\end{abstract}

Nos últimos momentos do Seminário, a negatividade dialética revelava-se uma força produtiva, capaz de desestabilizar as convicções dramáticas mais sólidas. Mais dos que nos textos, é na cena que ela será desenvolvida, deixando mais contraditória as relação entre palco e platéia. Flávio Império passou a trabalhar de modo cada vez mais experimental, como sugere no programa da peça:

"Meu trabalho passou por um processo de criação empírico. Surgido das idéias do texto, da visão humanística do autor: cada elemento toma do meio ao acaso, segundo as necessidades interiores dos personagens; uma muleta adaptada à cama sem pé, a flor que cobre o remendo; aliado ao sabor da coisa usada e gasta, longe da limpeza da coisa nova ou super racionalizada. Procurou o componente visual da realidade impressionista proposta pela

${ }^{193}$ Boal, Augusto. Programa da peça Pintado de Alegre, 1961, p. 4 
direção no que isto tem de fragmentação da cor, valorização dos detalhes em primeiro plano, pretendendo mais a atmosfera do que o real ${ }^{194 \prime \prime}$.

Entre a mobilidade e a imobilidade, entre o conserto e o remendo, o conceito de dramaturgia no Arena incluía o trabalho prático do palco.

\section{O Testamento do Cangaceiro}

O Testamento do Cangaceiro de Chico de Assis é a última peça encenada por meio do Seminário de Dramaturgia. Com ela fecha-se o ciclo de trabalho dramatúrgico mais experimental e coletivizado do Arena. $O$ texto teve suas primeiras versões efetuadas pelo autor antes da fundação do Seminário. ${ }^{195}$ No entanto, pode ser considerado uma produção do Seminário por ter sido discutido nas reuniões.

É significativo que essa peça herdeira da tradição da farsa popular e do teatro épico seja a última de um processo de reflexão critica sobre o modelo do drama.

\footnotetext{
${ }^{194}$ Império, Flavio. Programa da peça Pintado de Alegre, 1961, p. 6

195 É o próprio autor que comenta a data da escrita e das primeiras montagens de sua peça: "A primeira montagem foi na televisão, só a primeira parte do Cangaceiro, com a nossa Cleide Yaconis e o nosso incrível Leo Vilar, na televisão, dirigidos por Ademar Guerra... na Excelsior... Eu escrevi a primeira parte em 54. Aí teve uma montagem lá no rio Grande do Sul, com nossa querida Lilian Lemmertz" Assis, Chico. Entrevista In Capuani. Maria Lucida Damato. A Trilogia de Folheto de Cordel de Chico de Assis. Dissertação de Mestrado. Texto datilografado. ECA/USP, 2010. A peça também teve uma montagem amadora na EAD, dirigida por Silney Siqueira, quando este ainda era aluno, em 1959. Silva, Armando Sérgio da. Uma Oficina de Atores. A Escola De Arte Dramática de Alfredo Mesquita. São Paulo: EDUSP, 1989, p. 142
} 
A peça de Chico de Assis conta a história do sertanejo Cearim, que em uma caminhada pelo sertão nordestino enfrenta tentações do bem e do mal, como num auto religioso. Quem Ihe indica os caminhos é sua madrinha, que aparece a ele como visão divina. Ele passa por muitas provações numa região comandada pelo mandonismo, em que as terras são todas controladas pela igreja ou pelos coronéis.

Cearim em suas andanças irá encontrar personagens típicas da tradição popular, como o cangaceiro, o vigário, o sacristão, o delegado, a prostituta.

A peça se divide em quadros com títulos que descrevem as ações. A antecipação do tema auxilia a criar o clima farsesco e esfriar a surpresa sobre os acontecimentos. O que importa, assim, é o exame das peripécias da personagem. Tais recursos cênicos que remetem à tradição do teatro épico, foram utilizados a partir de um modelo brechtiano, como afirma o autor em uma entrevista recente: "Então veja você que no texto do Cangaceiro a peça que me serviu de inspiração foi A Alma Boa de Setsuan ${ }^{196 ",}$

Em outra frente, Chico de Assis se serviu de modelos da tradição popular brasileira, sobretudo o das narrativas de cordel. Em seu texto no programa do espetáculo, é essa a principal fonte formal mencionada:

"O que se procura é uma forma popular de espetáculo. Fomos buscar nossas bases na literatura popular e, principalmente, no "beletrismo" nortista. Não retiramos das obras consultadas as coisas de sabor típico. Tiramos a estrutura; uma estrutura já provada na prática. Investigamos o "contador de histórias", observamos seu comportamento estrutural e tentamos colocar tudo

\footnotetext{
${ }^{196}$ Assis, Chico. Entrevista In Capuani. Maria Lucida Damato. A Trilogia de Folheto de Cordel de Chico de Assis. Dissertação de Mestrado. ECA/USP, 2010, p. 67
} 
o que aprendemos e manipulamos em um espetáculo de teatro. Certas coisas são visíveis: o contador é axiomático, ninguém pode duvidar. Ele traz à vida personagens fantásticos, mas fala deles com naturalidade: "é assim e assim fica". A narração é episódica. De "causo"em "causo" se faz estória. A ação central está sempre se verificando na sua forma mais pura, se mostra em movimentos sempre diante dos olhos do espectador. $O$ personagem central incorpora esta ação. Todo o texto está sempre ligado diretamente à ação central ${ }^{197 \prime \prime}$.

Ao escrever $O$ Testamento do Cangaceiro, o autor quis acompanhar uma personagem popular que inverte as noções convencionais de heroísmo, na tradição da literatura picaresca ou da malandragem nacional. Sua ambígua trajetória é, entretanto, menos negativa do que a de José da Silva, na medida em que sua objetualização é de outro tipo. Boal, que dirigiu a encenação, em seu texto no programa da peça resume a trajetória de Cearim em três fases distintas e ascendentes no que se refere à aquisição de uma consciência social:

"Cearim atravessa três fases distintas. Na primeira confia a solução dos seus problemas terrenos aos poderes sobrenaturais. "Entra bem". Na segunda resolve se libertar; embora continue confiando no Céu, leva de quebra a espingarda na mão. Passa ele próprio a resolver os seus problemas. É a fase da liberdade anárquica, em que Cearim livremente toma a iniciativa de ganhar dinheiro as custas dos outros. A terceira, é a fase do compromisso. Cearim percebe que todo seu esforço deve ser canalizado para a luta coletiva, em defesa da causa comum ${ }^{198 \prime \prime}$

\footnotetext{
${ }^{197}$ Assis, Chico de. Programa da peça O Testamento do Cangaceiro, 1961, p. 6

198 Boal, Augusto. Programa da peça O Testamento do Cangaceiro, 1961, p. 1
} 
Assim, Cearim tem relativa consciência de sua condição, não sendo uma função do capital, o que resguarda uma medida de liberdade do ato individual. Chega a ter nítida consciência de seu papel social a ponto de conclamar seus iguais para organizarem uma revolta contra seus opressores. No entanto a convocação vem na chave da farsa, é inoperante e predomina o ridículo de alguém que não sabe nem conseguir comida.

Assim, seu maior heroísmo está mesmo na capacidade de sobreviver a todas as intempéries pelas quais passa na peça. De expediente em expediente, Cearim consegue se manter vivo e não morrer de fome, nem de bala. Seu salto qualitativo vem da consciência de que sozinho não terá forças para ir além da sobrevivência precária. É importante ressaltar que ele já se sabia explorado na primeira página da peça, quando em frente ao túmulo de seus pais, faz o seguinte pedido à sua madrinha:

\begin{abstract}
"Pelo menos queria que a madrinha mandasse um castigo para o Coronel dono dessas terras, que o danado tão logo parou de chover se escapou para a cidade deixando a gente meio com fome, meio com sede, meio morrendo. Bem que a madrinha podia mandar uma praga bem forte naquele filho de uma égua, que desse nele um quebrante desses de cair braço e perna ${ }^{199 "}$
\end{abstract}

E mesmo depois desse pedido tão enfático contra o coronel, ele ainda reitera que sua mão morreu de "eito" e que o coronel, "gordo que nem um capão na vida regalada, nem por isso deixa de ir à missa pensando na salvação."

Sua trajetória vai de uma revolta solitária à consciência da necessidade de união de seus iguais na luta por justiça social, mas o tom da farsa ameniza o sentido

${ }^{199}$ Assis, Chico de. O Testamento do Cangaceiro. Texto datilografado. 
revolucionário, criando um conforto formal, como parece notar Boal em seu texto no programa da peça:

"Fábula não se pode negar, tem suas vantagens. É coisa colocada no passado, em tom de conto de fada, história em quadrinhos, desenho animado. Em forma tão suave e brincalhona, é a melhor maneira de se permitir que Cearim diga o seu pensamento do mundo e da sua terra"

Pagando um certo preço da forma farsesca, o do uso de imagens de ações violentas que não produzem o efeito cabível, a peça estabelece uma cumplicidade com o público que em parte contradiz seu projeto crítico. Nas palavras de Eric Bentley, em seu estudo sobre a farsa:

"A pura agressão é apenas opressiva, como muitos desenhos animados cinematográficos ilustram. A pura frivolidade é maçante, como tantas comédias "ligeiras" ilustram. A relação dialética é de conflito e desenvolvimento ativos. Um diálogo tem de ser estabelecido entre a agresssão e a frivolidade, entre a hostilidade e a volubilidade ${ }^{201 " .}$

Mesmo oscilando entre posições que poderiam ser mais dialéticas, o Testamento do Cangaceiro demonstra a procura de personagens no limite da autoconsciência dramática. Sua fragmentação de caráter, que não permite ao herói se constituir completamente como sujeito, mas não o torna, por outro lado, completamente despossuído dela, como um "Zé Ninguém", é um caminho possível rumo a uma teatralidade épica. Cearim vive nesse fio tênue entre ser um sujeito plenamente

\footnotetext{
200 Boal, Augusto. Programa da peça O Testamento do Cangaceiro, 1961, p. 1

${ }^{201}$ Bentley, Eric. A Experiência Viva do Teatro. Rio de Janeiro: Zahar Editores, 1967, p. 221
} 
constituído e não ser ninguém. A dificuldade da peça é ter lidado com o novo, tema novo e forma nova. O desafio de seu caminho, complexo sobretudo quando se abandona o conforto do gênero, é superar o dualismo rumo à dialética. E foi essa, em cada momento, a grande luta de aprendizagem do Arena nos tempos do Seminário, a dialética. 


\section{Nota final}

Por conta de seu caráter exemplar, o Seminário de Dramaturgia acabou sendo replicado em diferentes cidades do país, como Rio de Janeiro, Porto Alegre, entre outras, tornando-se uma referência para todo escritor de teatro da década de 60 . A novidade de unir o estudo e a prática política e cênica é ainda hoje uma exigência complexa para grande parte dos artistas de teatro.

Há muito ainda a pesquisar sobre o assunto. Muitos documentos a descobrir e muitas entrelinhas a vasculhar. Esse trabalho pretende repor o assunto na discussão contemporânea sobre dramaturgia e teatro brasileiro, através de um caso em que o trabalho artístico só fazia sentido por almejar um diálogo complexo e autocrítico com um momento histórico, para além de qualquer formalismo. 


\section{Bibliografia:}

Abramo, Lélia. Vida e Arte. Memórias de Lélia Abramo. São Paulo: Editora Fundação Perseu Abramo, 1997

Adorno e Horkheimer. Dialética do Esclarecimento. Rio de Janeiro: Jorge Zahar Editor, 1997

Almada, Izaías. Teatro de Arena. Uma Estética de Resistência. São Paulo: Boitempo Editorial, 2004

Almeida, Inez Barros de. Panorama Visto do Rio. Teatro Cacilda Becker. Rio de Janeiro: INACEN, 1986

Bader, Wolfgang (Org.). Brecht no Brasil, São Paulo: Editora Paz e Terra, 1987

Bentley, Eric. A Experiência Viva do Teatro. Rio de Janeiro: Zahar Editores, 1967 O Teatro Engajado. Rio de Janeiro: Zahar Editores, 1969

Berlinck, Manoel T. O Centro Popular de Cultura da UNE. Campinas: Editora Papirus, 1984

Betti, Maria Silvia. Oduvaldo Vianna Filho. São Paulo: EDUSP, 1997

Boal, Augusto. 200 exercícios e jogos para o ator e não ator com vontade de dizer algo através do teatro. Rio de Janeiro: Editora Civilização Brasileira, 1982

Hamlet e o Filho do Padeiro. Rio de Janeiro: Editora Record, 2000

Teatro do Oprimido e Outras Poéticas Políticas. Rio de Janeiro: Editora Civilização Brasileira, 1980 Técnicas Latino-Americanas de Teatro Popular, São Paulo: Editora Hucitec, 1979

Boleslavski, Richard. A Arte do Ator. São Paulo: Editora Perspectiva, 1992 
Brecht, Bertolt. Estudos sobre Teatro. Rio de Janeiro: Editora Nova Fronteira, 2005

Campos, Cláudia de Arruda. Zumbi, Tiradentes. São Paulo: Editora Perspectiva, 1988

Carlson, Marvin. Teorias do Teatro, São Paulo: Editora da UNESP, 1997

Carvalho, Sérgio de. Introdução ao Teatro Dialético. Experimentos da Companhia do Latão. São Paulo: Expressão Popular, 2009

Carvalho, Tania. Paulo José. Memórias Substantivas. São Paulo: Imprensa Oficial, 2004

Chauí, Marilena. Cidadania Cultural. O Direito à Cultura. São Paulo: Editora Fundação Perseu Abramo, 2010

Clark, Barret H. European Theories of The Drama. New York: Crown Publishers, 1961 Costa, Iná Camargo. Sinta o Drama. Petrópolis: Editora Vozes, 1998 A Hora do Teatro Épico no Brasil. São Paulo:Editora Graal, 1996

Damasceno, Leslie Hawkins. Espaço Cultural e Convenções Teatrais na Obra de Oduvaldo Vianna Filho. Campinas: Editora da Unicamp, 1994

Engels, Friedrich. Anti- Duhring. São Paulo: Editora Paz e Terra, 1990

Escobar, Ruth. Maria Ruth. Rio de Janeiro: Editora Guanabara, 1987

Fernandes, Rofran. Ruth Escobar. 20 anos de Resistência. São Paulo: Editora Global, 1985

Garcia, Silvana. Teatro da Militância. São Paulo: Editora Perspectiva, 2004

Gassner, John. Rumos do Teatro Moderno. Rio de Janeiro: Editora Lidador , 1966

Góes, Marta. Alfredo Mesquita. Um Grã Fino na Contramão. São Paulo: Albatroz, Loqui e Terceiro Nome, 2007 
Hegel, Georg W. A Razão na História. Introdução à Filosofia da História Universal. Lisboa: Edições 70, 1995

Cursos de Estética. São Paulo: EDUSP, 2004

Jones, Margo. Theatre in The Round. New York: McGraw-Hill Book Company, 1965

Ledesma, Vilmar, Miriam Mehler. Sensibilidade e Paixão. São Paulo: Imprensa Oficial, 2005

Magaldi, Sábato Um Palco Brasileiro. O Arena de São Paulo. São Paulo: Editora Brasiliense, 1984

Moderna Dramaturgia Brasileira. São Paulo: Editora Perspectiva, 2008 , Vargas, Maria Thereza (Org). Cem Anos de Teatro em São Paulo. São Paulo: Editora SENAC, 2000 Teatro em Foco. São Paulo: Editora Perspectiva, 2008 Panorama do Teatro Brasileiro. Rio de Janeiro: Funarte, DAC/MEC, 1977

Marx e Engels. A Ideologia Alemã- I Feuerbach. São Paulo: Editora Hucitec, 1996 Moraes, Dênis de. Vianinha, Cúmplice da Paixão. Rio de Janeiro: Editora Record, 2000 Mostaço, Edélcio. Teatro e Política: Arena, Oficina e Opinião. São Paulo: Proposta Editorial, 1982

Nicoll, Allardice. The Theatre and Dramatic Theory, Connecticut: Greenwood Press, Publishers

Pace, Eliana. Renato Consorte. Contestador por Índole. São Paulo: Imprensa Oficial, 2005

Pallottini, Renata. O que é Dramaturgia. São Paulo: Editora Brasiliense, 2006 
Dramaturgia. Construção de Personagem, São Paulo: Editora Ática, 1989

Patriota, Rosangela. A Crítica de um Teatro Crítico. São Paulo: Editora Perspectiva, 2007

Vianinha. Um Dramaturgo no Coração de Seu tempo. São Paulo:

Editora Hucitec, 1999

Pavis, Patrice. Dicionário de Teatro. São Paulo: Editora Perspectiva, 2001

Peixoto, Fernando. Teatro em Movimento. São Paulo: Editora Hucitec, 1989

Entrevista com Gianfrancesco Guarnieri. In Encontros com a

Civilização Brasileira. Rio de Janeiro: Editora Civilização Brasileira, 1978

(Org). Vianinha. Teatro, Televisão, Política. São Paulo: Editora

Brasiliense. 1983

Piscator, Erwin. Teatro Político. Rio de Janeiro: Civilização Brasileira, 1968

Prado, Décio de Almeida. O Teatro Brasileiro Moderno. São Paulo: Editora Perspectiva, 2008

Prado, Luíz André do. Cacilda Becker, Fúria Santa. São Paulo: Geração Editorial, 2002

Raulino, Berenice. Ruggero Jacobbi. Presença Italiana no Teatro Brasileiro. São Paulo:

Perspectiva, 2002

Rosenfeld, Anatol. O Teatro Épico, São Paulo: Editora Perspectiva, 2006

O Mito e o Herói no Moderno Teatro Brasileiro. São Paulo: Editora

Perspectiva, 1996

Roubine, Joean-Jacques. A Linguagem da Encenação Teatral. Rio de Janeiro: Zahar Editor, 1998 
Roveri, Sérgio. Gianfrancesco Guarnieri. Um Grito Solto no Ar. São Paulo: Imprensa Oficial, 2004

Sarrazac, Jean-Pierre. O Futuro do Drama. Porto: Editora Campo das Letras, 2002

Schwarz, Roberto. O Pai de Família e Outros Estudos, São Paulo: Editora Paz e Terra, 1992

Silva, Armando Sérgio da. Uma Oficina de Atores. A Escola de Arte Dramática de Alfredo Mesquita. São Paulo: EDUSP, 1989

Siqueira, José Rubens. Viver de Teatro- Uma Biografia de Flávio Rangel. São Paulo: Nova Alexandria, 1995

Stal, Ana Helena Camargo de. Zé Celso Martinez Correa. Primeiro Ato. Cadernos, Depoimentos, Entrevistas. (1958-1974). São Paulo: Editora 34, 1998

Stanislavski, Constantin. Mi Vida em El Arte, Buenos Aires: Ediciones Diaspora, 1954

Szondi, Peter. Teoria do Drama Moderno (1880-1950). São Paulo: Cosac \& Naify, 2003 Teoria do Drama Burguês. São Paulo: Cosac \& Naify, 2004

Vanucci, Alesandra ( org.). Crítica da Razão Teatral. O Teatro no Brasil Visto por

Ruggero Jacobbi. São Paulo: Editora Perspectiva, 2005

Wilett, John. O Teatro de Brecht. Rio de Janeiro: Zahar Editores, 1967

\section{Depoimentos e entrevistas:}

Depoimentos I, II, III, IV, V e VI. Rio de Janeiro: SNT, 1978

Ferreira, Procópio. Revista Teatro Brasileiro. São Paulo: Editora Livraria Jaraguá LTDA, 1956

Almada, Izaías. Entrevista com Roberto Freire. In. Teatro de Arena. Uma Estética de Resistência. São Paulo: Boitempo Editorial, 2004 
Guarnieri, Gianfrancesco In Depoimentos V. Rio de Janeiro: MEC. SNT, 1981

Moya, Álvaro de. In Dionysos, número 24 São Paulo: Ministério da Educação e Cultura- Funarte, 1978

Muniz, Lauro César (Prefácio). Arena, Oficina e Outros Palcos. São Paulo: Editora Lazuli, SESC, 2005.

Ribeiro, Paula Chagas Autran. Entrevista com Nelson Xavier. Rio de Janeiro, novembro de 2011. Anexo.

\section{Peças Teatrais:}

Assis, Chico de. O Testamento do Cangaceiro. Texto datilografado, 1961

Barbosa, Benedito Ruy. Fogo Frio. Texto datilografado, 1959.

Boal, Augusto. Revolução na América do Sul. São Paulo: Massao Ohno Editora, 1960 -Arena Conta tiradentes. São Paulo: Editora Sagarana, 1967

Freire, Roberto. Gente como Gente, 1959, Texto datilografado.

Lima, Edy. A Farsa da Esposa Perfeita. Porto Alegre: Editora Garatuja, 1959

Migliaccio, Flavio. Pintado de Alegre, texto datilografado, 1961

Vianna Filho, Oduvaldo. Chapetuba Futebol Clube. In Oduvaldo Vianna Filho. Teatro 1. Rio de Janeiro: Edições Muro, 1981

\section{Artigos}

Betti, Maria Silvia Revisitando Chapetuba: uma análise de Chapetuba Futebol Clube. In Por uma militância teatral: estudos de dramaturgia brasileira do século XX. Campina Grande: Bagagem / João Pessoa: Idéia, 2005,

Giovannini, Luiz. Só o Faraó tem Alma in ://www2.uol.com.br/teatroarena/arena.html 
Gonçalves, Milton. Um Depoimento. in Dionysos, número 24 São Paulo: Ministério da Educação e Cultura- Funarte, 1978

Guimarães, Carmelinda. Seminário de Dramaturgia: Uma Avaliação 17 anos Depois. In Revista Dionysos, número 24. Rio de Janeiro: Ministério da Educação e Cultura-

Funarte, 1978

Guzik, Alberto e Pereira, Maria Lúcia (org.) Dionysos. Especial TBC. São Paulo:

Ministério da Educação e Cultura- Funarte. 1980

Lima, Mariângela Alves de. História das Idéias. In Dionysos, número 24. São Paulo:

Ministério da Educação e Cultura- DAC. Funarte, 1978

Mendonça, Luiz. Teatro é Festa Para o Povo. In Revista Civilização Brasileira. Caderno Especial Teatro e Realidade Brasileira. Rio de Janeiro: Editora Civilização Brasileira, 1968

Miranda, Nicanor. In http://www2.uol.com.br/teatroarena/arena.html

Pécora, José Renato. Ciclo de Palestras sobre o Teatro Brasileiro. Rio de Janeiro:

MINC INACEN, 1984

Soares, Lúcia Maria Mac Dowell. O Teatro Político do Arena e de Guarnieri. In Monografias, 1980. Rio de Janeiro: INACEN, 1983

\section{Textos Acadêmicos}

Capuani. Maria Lucida Damato. A Trilogia de Folheto de Cordel de Chico de Assis.

Dissertação de Mestrado. Texto datilografado. ECA/USP, 2010

Oliveira, Nicole Alcebíades de Estudo das técnicas do Seminário de Dramaturgia do Teatro de Arena: as tensões entre forma dramática e forma épica em Revolução na América do Sul. 2008. Iniciação Científica. (Graduando em Artes Cênicas) Universidade de São Paulo. Orientador: Sérgio Ricardo de Carvalho Santos. 
Scandolara, Camilo. Os Estúdios de Teatro de Arte de Moscou e a Formação da Pedagogia Teatral no Século XX. Dissertação apresentada ao Curso de Mestrado em Artes do Instituto de Artes, da Universidade Estadual de Campinas, para a obtenção do título de Mestre em Artes. 2006

\section{Sites Consultados}

Site do Actor's Studio: www.theactorsstudio.org

Site de Memória da Rede Globo de Televisão: www.memoriaglobo.com.br

Site do projeto Arena 50 Anos, da Cia Livre de teatro:

http:www.2.uol.com.br/teatroarena/arena.html.

Site da Associação dos Roteiristas do Brasil: http://www.ar.art.br

Site do professor Dr. Sérgio de Carvalho: http://www.sergiodecarvalho.com.br

Site sobre leis: www.jurisway.org.br.

\section{Programas de peças:}

Programa da peça A Farsa da Esposa Perfeita, de Edy Lima, 1959

Programa da peça Chapetuba Futebol Clube, de Vianinha, 1959

Programa da peça Eles não Usam Black Tie, de Gianfrencesco Guarnieri, 1958

Programa da peça Fogo Frio, de Benedito Ruy Barbosa, de 1960

Programa da peça Gente como a Gente, de Roberto Freire, 1959

Programa da peça Marido Magro Mulher Chata, de Augusto Boal, 1957

Programa da peça O Testamento do Cangaceiro, de Chico de Assis, 1961

Programa da peça Pintado de Alegre, de Flavio Migliaccio, 1961

Programa da peça Revolução na América do Sul, de Augusto Boal , 1960 
anexo 


\section{Entrevista com Nelson Xavier- 25/10/2011- Rio de Janeiro}

Paula-Vamos começar com o Seminário...

Nelson Xavier- Acho que a dificuldade que você está encontrando é por causa da memória, da gente ter que lembrar... Estamos mais ou menos em 57. Ano da estréia do Black Tie. Eu me formei na EAD e foi um desses anos que acontece tudo, eu acho, né? Às vezes acumula num ano só, tudo. O que eu não sei precisamente é como eu encontrei o Seminário. A verdade é que na minha memória me revela que eu já estava lá... é que a EAD tinha servido para mim, eu a procurei para estudar drama. Eu queria fazer cinema, mas não tinha onde estudar cinema, então, eu fui para a EAD. E lá é uma escola de atores, tanto é que fui reprovado na minha primeira tentativa de entrar lá. Não sei se no mesmo ano ou algum tempo depois eu voltei e entrei lá. Então, ao terminar a escola, eu já conhecia o Arena, eu já tinha uma peça escrita que foi absolutamente espinafrada porque eu não tinha noção, quer dizer e eu acho que eu tenho ele guardado, tenho até os escritos da EAD. O que me dá data é que logo depois que eu me formei como ator, Zé Renato me procurou em casa (eu morava na rua Guaianazes, no Centro de São Paulo, que já tinha o perfil de hoje, só não era a cracolândia.) para eu entrar no elenco do Arena para fazer... ele queria montar o Hamlet, e queria que eu fizesse o Claudius. Isso só serviu para que eu ... porque na verdade eu fiz Chapetuba, quer dizer, substitui o Henrique César no Black Tie, porque a temporada se estendeu. Isso que dá para mim, na minha memória a idéia que foi em 
57. Nessa altura eu já tinha contato com o pessoal do Arena, que era o elenco, menos o Milton, o Flavio já escrevia também, o Chico, uma moça do Sul...

Paula- Edy Fraga (SIC).

Nelson Xavier- Isso. Edy Fraga. Mais tarde apareceu o Jorge Andrade. É que foi freqüentando o Seminário que eu não sei como... eu estou fazendo um esforço para saber como eu entrei nessa... Bem, eu trabalhava em uma revista chamada Visão, é um tipo de jornalismo que nem tem mais, era uma versão de uma revista latinoamericana que chama Vision, mas que era quase tudo matéria traduzida e fazia alguma coisa para situar. O diretor da revista era o Naum Siroitzk. E eu fui trabalhar lá por causa do Eduardo Coutinho, que a gente era amigo de adolescência, eu o conheci no Museu de Arte, vendo filme mudo. Nessa revista eu escrevi uma coisa que até hoje eu me lembro como era... o impacto que aquilo me causou, o título que eu dei foi " $U m$ Italiano leva morro ao teatro", que me pereceu surpreendente que ele tendo nascido na Itália fosse o primeiro a trazer a favela. Então, eu já tinha escrito isso, deslumbrado evidentemente.

Paula- Quando você viu o Black Tie você ficou deslumbrado?

Nelson Xavier- É. Fantástico, uma coisa completamente revolucionária. Eu lembro da Lélia inesquecível e do Flávio Migliaccio. Era um tipo de interpretação deslumbrante. O Flávio cuspia as palavras, foi a primeira vez que eu vi isso, o texto não tinha importância. Era um ator moderníssimo. E a Lélia... Mas a favela no teatro é que me impressionou e eu comentei isso... Tudo isso para juntar datas. Eu não sei se eu fui procurando: ah! Deixa eu ler a minha peça, ou se eu já conhecia... Porque o Zé Renato 
eu conheci antes... Eu vi a primeira apresentação do Teatro de Arena que ele fez no primeiro andar do TBC, que funcionava na Major Diogo e o elenco permanente do Franco Zampari e tal, a Cacilda Becker estava na banca para me reprovar. Eu já conhecia o Ruggero Jacobi lá do Museu. A gente ficava impressionado com a erudição dele. Houve uma apresentação de Uma Mulher e Três Palhaços. Eu sei que a Eva Wilma e o John Herbert faziam um casal, ela dançava assim, fazia parte desse pequeno elenco, que foi uma demonstração do que era o teatro de Arena, teatro em círculo, eu vi isso, eu fui ver. Eu devo ter conhecido o Zé Renato desde então. Ali também funcionava a EAD, no mesmo edifício, a escola começou ali, depois mudou para a Rua Maranhão. Mas ali foi a primeira apresentação, acho que conheci o Zé Renato ali. Em seguida ele fez o Teatro de Arena, construiu. Eu não lembro o ano da chegada de Boal no Brasil.

\section{Paula- 56.}

Nelson Xavier- Então, quando o Zé Renato fez essa apresentação o Boal já estava no Brasil.

Paula- O Zé Renato convidou as pessoas para ir para o Arena, não?

Nelson Xavier- Não, não. Não era assim. Você conhece o Arena, tem o andar de cima com aquela mesa, a gente se reunia ao redor da mesa, aliás aquilo não era aberto, acho que tinha umas divisões e a gente ficava mais próximo. Eu acho que eu tive que... eu acho que eu me candidatei, eu não sei quem eu conheci primeiro. Era outro Brasil, eu acho que quando eu fiz exame de... mais de uma vez.. Havia um teatro na Vila Buarque, o Leopoldo Fróes, perto da Rua Veridiana... Eu sei que eu tirei boa 
nota, era CDF para caralho, apaixonado e tal e eu tirei uma nota surpreendente para como eu havia começado. Eu não era ator, nunca pensei em ser ator, coisa que aprendi para poder sobreviver. Era como se a gente... não era a mesma turma... a escola e o TBC, o Alberta D'aversa também foi meu professor, como é que eu vou dizer... a gente se freqüentava, não éramos amigos, mas era uma coisa próxima, acho que tinha isso que me fez descobrir que tinha um lugar que se pudesse... lembrar que eu procurei a EAD para estudar drama, portanto, o Seminário de Dramaturgia eu devo ter ficado...ih! É isso! Só isso que eu sei te dizer.

\section{Paula- Você queria escrever?}

Nelson Xavier- Não, eu já escrevia.

Paula- Então, mas a sua vontade quando você foi era...

Nelson Xavier- Era escrever para cinema, para teatro, entender a linguagem do drama e a partir do momento que... bom,como funcionava você sabe: a gente lia, Boal esculhambava porque ele citava muito Brunetiere, Henry Bergson, e depois que você lê uma peça do jeito que a crítica era feita, a abertura com que se falava do trabalho do outro, a liberdade que a gente naturalmente desfrutava para falar do trabalho do outro, era uma coisa inédita para mim e depois eu nunca mais vi no Brasil, porque não só o Brasil mudou todo, ficou uma sociedade muito mais conformista e paralisada, as pessoas principalmente paralisadas. Para você ter uma idéia havia o costume de na véspera da estréia ou quase por aí havia um espetáculo para a classe, era uma tradição, ou depois de estrear e falava-se tudo, todo mundo, mesmo desconhecido: não, isso tá ruim... havia uma liberdade que depois eu nunca mais vi. 
Imagina no Seminário, e o Boal vindo com toda a ciência dele, do Actor's Studio e dos americanos, mas ele descia uma lenha. Mas era de uma saúde poder falar abertamente assim. Eu me lembro que as pessoas ficavam um pouco... o Jorge Andrade que era posudo, ele chiou bastante, as pessoas chiavam bastante, porque pô... mas ao mesmo tempo abria a cabeça da gente. Tanto que quando o MCP, que era a instituição mais avançada do Brasil culturalmente falando, e foi o modelo que o Vianna pegou para fazer o CPC, eles me pediram e eu quis fazer lá e fiz. Eles me contrataram para fazer teatro lá e montei o Mutirão que virou Julgamento de Novo Sol e eu não me lembro... Ah! Peças do Luis Marinho e gente debateu lá no Seminário com Luis Mendonça, que era o chefe de Departamento de Teatro. Já eles lá na verdade já tinham a mesma mentalidade do Seminário, porque era o Paulo Freire junto com o Germano Coelho que dirigiam o MCP então essa liberdade lá era até mais natural do que aqui era menos buscada, era natural. Em Pernambuco a gente enxergava o futuro achava que ia mudar o país mesmo, o governo de Arraes era uma efervescência extraordinária. Me lembrei de um detalhe que era importante também... então houve um início de Seminário também no Recife, mas é que Pintado de Alegre do Flavio Migliaccio foi debatido, Gente como a Gente foi debatido, foi espinafradíssimo, o Roberto nunca mais falou comigo.

Paula- Mas ele diz que foi importante para ele as discussões.

Nelson Xavier- Foi, mas ele rompeu comigo. Rompeu um pouco porque eu tinha passado... Ele tinha uma casa bonita em Campos do Jordão, passamos uns dias lá, ele me convidou e discutimos e conversamos sobre a peça Gente como a Gente e eu estava aprendendo e achando maravilhoso e a peça foi lida e o Boal acabou com 
ela e eu entendi o Boal, eu compreendi que ele estava certo e foi como se eu mudasse de lado. Ele se sentiu traído e nunca mais falou comigo, mas é... (risos). Genial o Roberto. Então, tinha esse grau de liberdade de crítica.

Paula- De que modo essas discussões se refletiam na escrita e na interpretação?

Nelson Xavier- Isso aconteceu com o Gente Como a Gente, que a gente acabou montando. Eu não reescrevi a minha. Eu escrevi uma outra que acabou não sendo lida. Uma história de um mendigo que foi incendiado por uns playboys. Mas acho que não foi lida. Eu dei para o Paulo Francis ler. Eu me lembro da Edy Lima, do Pintado de Alegre, do Gente como a Gente, que depois eu fui assistente do Boal, aí eu pensei que ah! Bom, agora eu estou retomando meu projeto primeiro que era direção, fui assistente do Boal, para dirigir Gente como a Gente. Mas é isso, a gente refazia, a Edy Lima voltou mais de uma vez, o Jorge Andrade também. Pintado, então, foi feito ali mesmo, em cima do joelho. O Flavio praticamente vivia ali, eu tinha um apartamentozinho, o Flavio acho que dormia ali.

Paula- Diz-se que sim.

Nelson Xavier- Sim, né? Então, era a vida cotidiana. O Seminário, teatro, peça. Tudo era uma coisa só.

Paula- Não tinha uma "compartimentação"? De que modo isso influenciava na interpretação? 
Nelson Xavier- A gente fazia... Começou-se a falar em laboratório, então, né? Laboratório a gente fazia para a peça. O texto podia mudar durante o ensaio e mudava, mas... a busca de uma maneira... não é que a gente dava um ítulo: vamos buscar uma interpretação brasileira, mas a gente tendia como modelo o homem da rua, o operário, representante do sindicato. E a gente queria fazer o homem comum, o homem do povo e o Laboratório era feito em busca de uma interpretação que levasse a isso. Ainda que quando eu vi o Black Tie o Flávio me encantou porque para mim... eu vinha da EAD... quando eu entrei... teve até um crítico que destacou isso, eu era meio teatrão ainda, eu tinha aprendido, eu não era espontâneo que nem eles, eu tirei boa nota, mas longe de fazer aquela coisa cuspida que o Flávio fez. Que a gente chamou de estilo passarinho, realmente não era importante o texto. Para mim... eu ainda era muito educado, muito formal para fazer teatro, mas eu via isso, tinha a capacidade de ver o Flávio... buscava aquilo. Mas essa coisa que você falou de não ser compartimentada... não era, porque era no mesmo edifício, a gente morava, comia junto... dormia junto, enfim.. Ensaio era também tudo misturado...

Paula- Então, a dramaturgia e a interpretação tinham essa ligação umbilical?

Nelson Xavier- É porque era full time, a gente pensava, discutia, comia junto, dormia junto...

Paula- Nesse sentido... por essa interpretação brasileira.. o que se fala é que não tinha texto e que a interpretação brasileira precisava desse texto brasileiro ...

Nelson Xavier- Exatamente.

Paula- Então, uma coisa acabou sendo completamente ligada a outra, né? 
Nelson Xavier- Uma coisa que outro dia eu vi que... o Boal, outro dia eu fui ver o documentário sobre ele e ele dizia que a gente não montava só teatro nacional, que tinha que ser brasileiro, como só a primeira peça, a segunda peça a gente não montava. Peça de estreante mesmo, exatamente para estimular novos autores, então, era uma coisa que era elaborada mesmo no final era no ensaio que acabava.

Paula- A última versão?

Nelson Xavier- Não, ele que me lembrou que era só autor estreante. Então, isso aconteceu muito com Gente como a Gente e Pintado de Alegre. A Edy Lima também foi montada, mas eu não estava mais no Arena, Gente como a Gente, sim, que eu fui assistente e Pintado de Alegre que eu não fui assistente eu acho, mas eu acompanhei, não lembro no Pintado de Alegre de eu ter sido assistente, mas mexia porque o ator fazia parte do elenco.

Paula- E como era essa dinâmica? Tudo bem, era tudo conjugado e interpretação e tal, mas como era a dinâmica? O autor assistia e ali mesmo ele dizia, olha, isso aqui acho que não tá bom, era o diretor, tinha uma dinâmica que vocês seguiam?

Nelson Xavier- (Ri). Dinâmica? Não sei. Não sei. Não, era tudo junto. (Ri). Eu me lembro de botar o Vianna ajoelhado contra a parede lá no sótão, ele se concentrando, isso no Gente como a Gente, mas não me lembro se... não, era isso mesmo, essa dinâmica, na hora do ensaio, ensaiava... Havia uma coisa de "reuniãonismo", tudo era coletivo, todo mundo era comunista, me tornei comunista lá. 
(ri). Então... Para comprar um fósforo fazia uma reunião. (Ri). Ai que horror... Maravilha.

Paula- Não era o diretor que determinava se era assim ou não?

Nelson Xavier- Não, a autoridade do Boal, o Boal era inteligente para caramba, uma das pessoas mais inteligentes que encontrei. E ele fazia assim... (Ri). Aquele narigão dele... ele, na verdade, dominava porque era o mais preparado, e o que tinha as coisas mais claras na cabeça, então, ele acabava convencendo todo mundo das idéias dele, mas havia muito pau também. Muita discussão.

Paula- Então, não tinha a palavra final de um diretor?

Nelson Xavier- Tinha.

Paula- Não, a palavra final era dele, lógico. Mas durante esse processo?

Nelson Xavier- Não, discutia-se muito. Argumentava-se muito. Eu quando a minha peça foi discutida eu não estava bem à vontade para poder... nem sabia...mas com o tempo a gente discutia muito, todos. Era totalmente democrático, no sentido real da expressão. A direção acabava sendo dele porque ele convencia a gente, né? Ele era muito esperto, muito sabido, muito genial, né?

Paula- No Seminário, então, ele não teria a apalavra final?

Nelson Xavier- No Seminário, sim. Eu estou falando das peças. Da encenação.

Paula- Cada um falava o que achava do seu personagem? 
Nelson Xavier- Tudo, todo mundo falava tudo... Eu não me lembro, pode ter havido, mas eu não me lembro, da presença do autor nos ensaios. Quando o autor não fazia parte do elenco. Teve uma peça do Chico, não teve? Que eles chamaram o Lima para fazer... Não me lembro o nome...

Paula- Testamento do Cangaceiro.

Nelson Xavier- Essa então ele mudava bastante. Isso. Tudo isso são memórias esparsas.

Paula- Não teve outro momento como esse mesmo, como você afirmou...

Nelson Xavier- Não teve, mesmo a minha reprodução lá em Pernambuco, eu falava e quase não tinha contestação. Não havia essa...

Paula- Para você ir para lá eles te convidaram...

Nelson Xavier- Nós fomos para o Sul, depois para lá em excursão com as peças e a gente ficou chocado, chocado... já tínhamos lido... A expressão "realidade brasileira" estava sendo cunhada naquela época, o ISEB estava sendo fundado. Depois o CEBRAP mais tarde, quando chegamos lá e vimos aquele nível de miséria... e a gente vinha de São Paulo. Eu fiquei maravilhado com o MCP. Também não me lembro se eu ofereci o texto, ou se eu ofereci trabalho, eu sei que falei na... Outro dia o MST esteve aqui para pegar o texto para eles fazerem aí pelo rádio. O Julgamento não foi feito para o Seminário, acho que nem passou por lá, mas te contaram como ele foi feito?

Paula- Não. 
Nelson Xavier- É o seguinte: me impressionou muito o levante, um movimento de resistência camponesa no Noroeste de São Paulo, em Jales. Eu acho que eu me liguei, não sei quem me chamou para isso e eu me lembro da gente trazer o cara que foi libertado da prisão em 1 de janeiro, relaxaram a prisão dele, nós trouxemos ele para o Arena e eu botei um gravador e fiquei fazendo perguntas para ele e foi desse material que a gente escreveu, eu acho que o Boal escreveu... começou a escrever a primeira fala que é do juiz, ou do representante do governo, ou do do latifúndio, mas depois eu fiz a peça e me sinto responsável porque tinha gente como o Modesto Carone, como o Benedito Araújo que depois fez cinema, havia várias pessoas interessadas, mas eu acabei ficando padrinho da coisa e aquele texto tinha que montar. E eu não sei se eu ofereci ou... porque as ligas camponesas tornavam o trabalho no campo primeira página, organização do campo, sindicatos dos trabalhadores do campo e sei que isso os interessou e me contrataram para isso, ganhei um salário altíssimo que depois me arrependi de ter pedido um salário tão alto, porque eles pagaram! Eu achava que ia mudar o Brasil e tinham me contratado para fazer isso! Era o paraíso, mas eu classifico como uma peça documental, no sentido de que só o Seminário me permitiu entender teatro a nesse nível de pegar um gravador e fazer a peça, uma peça documental.

\section{Paula- Em que sentido?}

Nelson Xavier- Peguei o cara, a realidade gravada e vamos dar uma forma teatral a isso. Foi uma coisa que saiu do forno mesmo, de uma mentalidade de Seminário.

Paula- O que você chama de mentalidade de seminário? 
Nelson Xavier- No sentido de que para mim de formação bem pequeno burguesa que as coisas têm que ser no lugar certo, sabe essa coisa... pequeno burguesa mesmo... era uma maneira de buscar um texto vivo naquele momento... $O$ Black Tie já tinha avançado bastante nesse sentido de ser fiel, esse era o máximo, não era uma coisa craniada não... Era pegar a realidade e trazer ela mesma, fiquei louco com aquilo.

Paula- E aí o conhecimento estrutural da dramaturgia para poder fazer isso...

Nelson Xavier- Isso aí eu não lembro como foi... A peça ficou pronta, eu acho que o Boal bateu uma espécie de... É um texto que hoje ficou esquemático, mas naquela época era muito branco branco preto preto. Realismo socialista era autêntico, mas eu acho que é fruto dessa mentalidade, dessa sem cerimônia com o uso do real no dramatúrgico. Completamente livre, direto, né? Sem dúvida, estou pensando nisso pela primeira vez, mas é fruto disso, dessa experiência.

Paula- Tem além disso que te deixou à vontade de fazer isso que é um conhecimento técnico que vocês tinham, né? Na lida com a leitura, na discussão...

Nelson Xavier- É. O Boal com o negócio do Brunetiere, tinha essas regras. Na verdade eu acho que a gente entendia mais o que era conflito. O sentido de conflito era mais claro, mais vivo na cabeça. Porque o diálogo e o desenvolvimento da história eu nunca mais vi, mas acho que satisfazia também...

Paula- O fulcro do estudo da estrutura dramatúrgica era a questão do conflito. 
Nelson Xavier- E que ao pegar o material gravado a gente não pensava: ah! Vamos fazer conflito. Não havia essa coisa. Eram personagens... E a montagem era boa, o pessoal de Pernambuco era muito bom... Como eu vou explicar? Porque como você coloca parece que a gente aprendia regras no Seminário e as aplicava. Não existia isso...

Paula- Não. Estou falando da estrutura. Não como regras a serem seguidas. Mas de tanto discutir, ler, etc... Vocês eram capazes de pegar aquele material e transformar em uma peça.

Nelson Xavier- Vai ficando espontâneo, natural, um primeiro gesto.

Paula- Mas tem teoria, é como se fosse um castelo teórico dramatúrgico que fica muito mais por que é sem cerimônia, de discussão, muito mais do que se vocês ficassem falando de regras formais.

Nelson Xavier- Mexe mais no conteúdo do que na forma.

Paula- Mas a forma estava lá, né? Porque antes você disse que escrevia peças, mas não tinha noção...

Nelson Xavier- É. Você está me lembrando da cotidianeidade dessa coisa, a continuidade desse trabalho. Eu acho que a gente se reunia uma vez na semana né? Sábado...

Paula- É. Sábado de manhã

Nelson Xavier- De manhã. Um horário chato! Será que a peça passou pelo Seminário? Não consigo me lembrar disso... 
Paula- Bom, pelo menos não há registro disso, mas há tão pouco registro em geral mesmo, Nelson. Mas mesmo que isso não tenha passado por lá, pelo que eu estou entendendo essas discussões se fizeram muito presentes na hora de fazer, né?

Nelson Xavier- Nossa, muito. É que na verdade o Seminário ensinava teatro para a gente. A gente pensava teatro, pensava a natureza do drama mesmo.

Paula- O pensamento, acho que era a diferença, né?

Nelson Xavier- É o pensar teatro, pensar drama. Que impregnava a gente. A gente ficava alerta. A gente achou que a peça da Edy Lima foi por boa vontade do Boal. A gente não defendeu aquele texto, não. Bom, a gente era tão sectário, tão stalinista, meu Deus... (risos). Ontem eu fui ver um filme do Zhang Yimou que se passa na Revolução Cultural da China que me lembrou muito o Arena, o partido... claro que o deles era completamente enlouquecido, mas a gente era muito perto daquilo. Era muito preconceituoso.

Paula- Que bom que se montou, afinal, foi o único texto de uma mulher. E essa parte da política que a gente está falando mais partidária entrava de que jeito?

Nelson Xavier- Partidária, não. Mais ideológica... Eu me filiei em Pernambuco, eles... apesar que a gente não percebia eles indo para reunião de partido, não...

Paula- Nem dava tempo, né?

Nelson Xavier- Não!

Paula- A política era mais pelo viés ideológico? 
Nelson Xavier- Não, era mais trabalhar com sindicato, mais pensar em nome do povo. Era voltado para o teatro, voltado para o drama. Tudo se voltava para o drama, só se pensava nisso e como representar esse homem da rua.

Paula- A necessidade desses textos novos. Fala-se que não tinha textos, mas tinha, né?

Nelson Xavier- Tinha. Tinha um monte de candidatos que eram recusados. Ah! Fogo Frio. Ih! O Ruy Barbosa penou para caralho.

Paula- Mas perseverou.

Nelson Xavier- Ele era um CDF.

Paula- E vocês reliam todas as versões?

Nelson Xavier- Não eram lidas todas as versões. Acho que sim.

Paula- Por que Chapetuba está dito que teve sete versões. E fiquei pensando como se dava isso, traz, relê, traz de novo...

Nelson Xavier- Acho que tinha não de ler tudo, mas de trazer cenas, trazer pedaços, de conversar durante a semana sobre isso. O Seminário era no sábado, chato, cedo, mas a gente conversava sobre isso durante a semana, convivia. Aquela cena fiz isso, fiz aquilo...

Paula- E quando você foi... a sua idéia de montar um Seminário...

Nelson Xavier- Eu não sei. Sei que juntou lá... Eles deviam ter notícias do Seminário. Eu não precisei convencer ninguém. Quando eu me instalei lá, eu sei que o 
Luís Marinho estava presente e era uma pessoa muito humilde. Não sei se o Wilker também estava, porque ele fazia parte. Ele não fazia quase nada, ficava meio observador, mas eu o conheci lá no MCP. Tinha gente alheia ao teatro também, mas por curiosidade. O Glauco que foi cenógrafo. Não me lembro, Paula.

Paula- Não tem problema. O que você levou para o Recife quando instituiu lá um novo Seminário?

Nelson Xavier- O que eu levei mais foi a liberdade de crítica. Confiar no gosto, confiar no primeiro toque e abrir, porque o tempo fez isso na minha cabeça também. Porque no curso desses anos eu vi o Brasil silenciar essas coisas, vi essa sociedade ficar cada vez mais calada, hipócrita, então eu acho que estou atribuindo ao Seminário mais a capacidade não de eu ter um arcabouço de regras, mas de abrir o verbo, a discussão. Eu sei que o Luis Marinho... provavelmente discutimos peças dele, pois foi o primeiro autor que u conheci em Pernambuco. Fascinante. E teve também eu me deslumbrar, descobrir um pouco o Nordeste nessa dramaturgia. Então eu não sei como eu dirigi esse Seminário lá. Eu era uma outra pessoa, tinha uma confiança em mim que vinha do Sul sabendo tudo, muito arrogante, mas o impacto do Nordeste em mim foi muito grande, eu fiquei fascinado com o trabalho das pessoas. Paulo Freire, me deslumbrei com aquele negócio, lembro dele falando: é o inverso, a gente ensina, mas a gente tem que aprender. A gente tem que usar o vocabulário que eles têm para trabalhar. Que era o que a gente tinha feito. Mas eu tinha ... O que mais era importante era a sem cerimônia para poder falar do trabalho do outro. A gente brigava muito, éramos sectários sim. 
Paula- Em que sentido?

Nelson Xavier- Tinha que dar recado político, eu tenho a impressão, porque a gente era muito ... Tinha muito isso de teatro de esquerda e naquela época havia muito uma moda de denúncia, que depois eu passei a me incomodar muito com isso, porque você dá o quadro da situação e denuncia o que está acontecendo, uma profunda injustiça, então conta um quadro de injustiça flagrante, clamorosa. E você tem que acompanhar isso por dentro, ao invés de apontar a denúncia, demonstrá-la, fazer que ela apareça por si só, que eu acho uma maneira mais avançada de ... menos denuncista, menos esquerdista... menos esquemática, então, nesse momento foi quando eu descobri isso vindo para Pernambuco nesse período, eu fui para o Nordeste em 60. Vivi isso de 57 a 60 eu vivi isso, mas já estava me incomodando e o teatro que eu encontrei no Nordeste, do Luís Marinho, era um teatro nesse sentido ingênuo, inocente, ele estava descrevendo, por exemplo, o diabo... Por exemplo o diabo para um cara como eu da esquerda que não acreditava naquilo, era algo meio folclórico. Depois é que descobri a beleza verdadeira disso. Havia da parte da gente uma atitude meio censória do que não fosse denuncismo, um texto que não ficasse claramente crítico em relação á sociedade. Havia muito isso, da parte do Boal também, depois ele ficou até mais.

Paula- Mas os textos não tinham isso. Parece que os textos eram mais importantes em lançar o autor era maior do que esse resto.

Nelson Xavier- Havia premência, por exemplo, Gente como a Gente foi montado meio a revelia do Boal. Não havia outro texto. Ele achava muito... os 
personagens não eram reais, os personagens eram fabricados, tinham uma mentalidade católica que o incomodava e também me incomodava, como se o conflito não fosse real, tinha um pouco de pó de arroz em tudo. Porque faltava texto, a gente tinha que montar brasileiro, tinha essa bandeira, a Edy Lima foi montada assim o próprio Fogo Frio, não havia texto. Tinha que montar o texto que existia. O meu texto não foi montado porque era muito ruim, tinha muito de memória, eu me inspirei na família da minha tia, era muito cru. Uma tia que morava muito mal, num cortiço.... (Toca o telephone). Vou atender...

Paula -Vai lá...

(Tempo).

Nelson Xavier- Você quer ver o meu material da EAD?

Paula- Vamos.

FIM 